\title{
Total Synthesis of Mannopeptimycin $\beta$ via $\beta$ - Hydroxyenduracididine Ligation
}

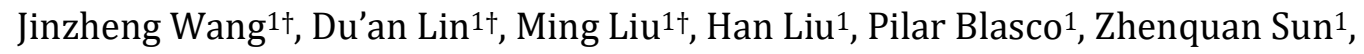
Yan Chu Cheung 2 , Sheng Chen², Xuechen $\mathrm{Li}^{1}{ }^{*}$

1 Department of Chemistry, State Key Laboratory of Synthetic Chemistry, The University of Hong Kong, Pokfulam Road, Hong Kong SAR (P. R. China).

2 Department of Infectious Diseases and Public Health, The City University of Hong Kong. Hong Kong SAR (P. R. China)

$\dagger$ Equal contribution

\section{Supporting Information}

I. General information 2

II. Synthesis of building blocks

i. $\quad$ Synthesis of $L-\beta$ hEnd 3

ii. $\quad$ Synthesis of $N$-Man- $D-\beta$ hEnd $\quad 8$

iii. Synthesis of Boc- $\beta$ MePhe-OH 16

$\begin{array}{ll}\text { iv. Synthesis of tripeptide } & 16\end{array}$

III. Boc-SPPS and total synthesis of mannopeptimycin $\beta \quad 19$

IV. Lipid II binding test of the synthetic mannopeptimycin $\beta$

V. Unsuccessful attemps towards mannopeptimycin and the evolution of the strategy 36

i. Other attempts toward the synthesis of $N-\alpha$-mannosylated D- $\beta$ hEnd 36

ii. Attempts towards the total synthesis of mannopeptimycin via solution phase peptide synthesis 37

iii. NMR Spectra $\quad 42$

$\begin{array}{lr}\text { iv. Reference } & 65\end{array}$ 


\section{General information}

Commercially available chemicals (Energy Chemical, J\&K Scientific, TCI, Dieckmann, Shenzhen Pepbiotic) were used without further purification. The Sugar donor and Boc-D- $\beta \mathrm{MePhe}-\mathrm{OH}$ was prepared according to the literature ${ }^{[1]}$. Fmoc protected L-vinylglycine benzyl ester $\mathbf{4}$ and Boc protected D-vinylglycine methyl ester 5 are commercially available (Shenzhen Pepbiotic Co. Ltd) and could also be obtained according to the literature ${ }^{[2]}$. All solvents were reagent grade or HPLC grade (RCI or DUKSAN). Anhydrous dichloromethane $\left(\mathrm{CH}_{2} \mathrm{Cl}_{2}\right)$ was prepared from distillation with calcium hydride $\left(\mathrm{CaH}_{2}\right)$. All reversed-phase (RP) high-performance liquid chromatography (HPLC) separations involved a mobile phase of $0.1 \%$ trifluoroacetic $\operatorname{acid}(\mathrm{TFA})(v / v)$ in acetonitrile $\left(\mathrm{CH}_{3} \mathrm{CN}\right) / 0.1 \% \operatorname{TFA}(v / v)$ in water $\left(\mathrm{H}_{2} \mathrm{O}\right)$. Waters UPLC H-class system was applied for analytical purpose, which equipped with an ACQUITY UPLC photodiode array detector, a Waters SQ Detector 2 mass spectrometer and a Waters ACQUITY BEH C18 column $(1.7 \mu \mathrm{m}, 130 \mathrm{~A}, 2.1 \times 50 \mathrm{~mm})$ at a flow rate of $0.4 \mathrm{~mL} / \mathrm{min}$. Preparative HPLC was performed on Waters HPLC system including a quaternary pump (Waters 2545), a UV/Vis detector (Waters 2489) and a Grace Vydac 218TPTM C18 column $(10 \mu \mathrm{m}, 300 \mathrm{~A}, 22 \times 250 \mathrm{~mm})$ at a flow rate of $10 \mathrm{~mL} / \mathrm{min}$. The results were analyzed with Waters Masslynx software. Analytical TLC was performed on E. Merck silica gel 60 F254 plates and visualized under UV light $(254 \mathrm{~nm})$ or by staining with ninhydrin. Flash column chromatography on silica gel was performed on E. Merck 230-400 mesh silica gel $60 .{ }^{1} \mathrm{H}$ and ${ }^{13} \mathrm{C}$ nuclear magnetic resonance (NMR) 
spectra were recorded at $298 \mathrm{~K}$ on Avance DRX Bruker 400, 500 and $600 \mathrm{MHz}$ FTNMR Spectrometer. Chemical shifts are reported in parts per million (ppm) and are referenced to solvent residual signals.

\section{Synthesis of building blocks}

\section{i. $\quad$ Synthesis of $L-\beta \mathrm{hEnd}$}

\section{Compound 6:}

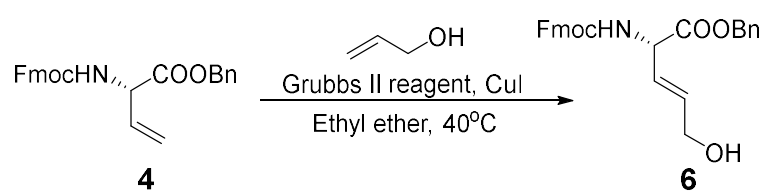

To the solution of compound $4(4.00 \mathrm{~g}, 9.68 \mathrm{mmol}), \mathrm{CuI}(184 \mathrm{mg}, 0.97 \mathrm{mmol})$ and Grubbs II catalyst (239 mg, $0.29 \mathrm{mmol})$ in dry diethyl ether $(50 \mathrm{~mL})$ was quickly added allylic alcohol $(2.01 \mathrm{~mL}, 29.60 \mathrm{mmol})$ with the protection of argon at room temperature. After refluxing for $4 \mathrm{~h}$, the reaction mixture was concentrated in vacuo and purified by silica gel flash chromatography $(n$-hexanes/EtOAc $=5: 4)$ to give $3.50 \mathrm{~g}$ of compound 6 as brown solid in $82 \%$ yield. ${ }^{1} \mathrm{H}$ NMR $\left(400 \mathrm{MHz}, \mathrm{CDCl}_{3}\right) \delta 7.75(\mathrm{~d}, J=7.5 \mathrm{~Hz}, 2 \mathrm{H})$, $7.58(\mathrm{~d}, J=7.3 \mathrm{~Hz}, 2 \mathrm{H}), 7.44-7.26(\mathrm{~m}, 9 \mathrm{H}), 5.88(\mathrm{~m}, 1 \mathrm{H}), 5.78(\mathrm{dd}, J=15.6,5.3 \mathrm{~Hz}$, 1H), $5.63(\mathrm{~d}, J=7.8 \mathrm{~Hz}, 1 \mathrm{H}), 5.24-5.11(\mathrm{~m}, 2 \mathrm{H}), 4.97(\mathrm{t}, J=6.4 \mathrm{~Hz}, 1 \mathrm{H}), 4.40(\mathrm{~d}, J$ $=7.0 \mathrm{~Hz}, 2 \mathrm{H}), 4.20(\mathrm{t}, J=6.8 \mathrm{~Hz}, 1 \mathrm{H}), 4.12(\mathrm{~m}, 2 \mathrm{H}), 1.79(\mathrm{~s}, 1 \mathrm{H}) .{ }^{13} \mathrm{C} \mathrm{NMR}(100 \mathrm{MHz}$, $\left.\mathrm{CDCl}_{3}\right) \delta 170.62,155.76,143.92,141.48,135.19,133.22,128.82,128.75,128.47$, 127.91, 127.27, 125.24, 125.01, 120.18, 67.77, 67.28, 62.55, 55.51, 47.29. HR-ESI-MS 
(m/z): calcd for $\mathrm{C}_{27} \mathrm{H}_{25} \mathrm{NO}_{5} \mathrm{H}^{+}\left(\mathrm{M}+\mathrm{H}^{+}\right)$: 444.1733, found: 444.1659 .

\section{Compound 7:}

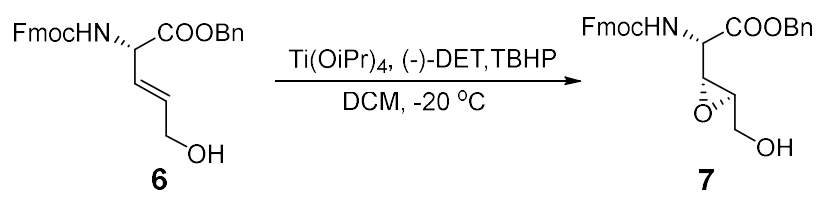

To a flask charged with 4A molecular sieves $(3.00 \mathrm{~g})$ in dry DCM $(15 \mathrm{~mL})$ were added (-)-DET $(1.73 \mathrm{~mL}, 10.12 \mathrm{mmol})$ and $\mathrm{Ti}(\mathrm{O} i \mathrm{Pr})_{4}(2.43 \mathrm{~mL}, 8.28 \mathrm{mmol})$ at $-20^{\circ} \mathrm{C}$. The resulting mixture was continued to stir at $-20^{\circ} \mathrm{C}$. After $30 \mathrm{~min}$, tert-butyl hydroperoxide solution (TBHP) (5M in hexane, $5.52 \mathrm{~mL}, 27.60 \mathrm{mmol})$ was added dropwise. The mixture was stirred at $-20^{\circ} \mathrm{C}$ for another $30 \mathrm{~min}$. Compound $6(4.07 \mathrm{~g}, 9.20 \mathrm{mmol})$ in DCM $(15 \mathrm{~mL})$ was then added dropwise and the resulting mixture was kept at $-20^{\circ} \mathrm{C}$ for $8 \mathrm{~h}$. The reaction was then diluted with diethyl ether $(60 \mathrm{~mL})$ and quenched with saturated $\mathrm{Na}_{2} \mathrm{SO}_{4}(8.30 \mathrm{~mL})$. The mixture was stirred at room temperature for $3 \mathrm{~h}$ and filtered through celite, the filtrate was subsequently concentrated in vacuo. The resulting residue was purified by silica gel flash chromatography $(n$-hexanes/EtOAc $=$ 5:4) to give $3.20 \mathrm{~g}$ of compound 7 as a white solid in $75 \%$ yield. ${ }^{1} \mathrm{H}$ NMR (400 MHz, $\left.\mathrm{CDCl}_{3}\right) \delta 7.76(\mathrm{~d}, J=7.5 \mathrm{~Hz}, 2 \mathrm{H}), 7.57(\mathrm{~d}, J=7.4 \mathrm{~Hz}, 2 \mathrm{H}), 7.43-7.28(\mathrm{~m}, 9 \mathrm{H}), 5.62$ $(\mathrm{d}, J=7.8 \mathrm{~Hz}, 1 \mathrm{H}), 5.27-5.18(\mathrm{~m}, 2 \mathrm{H}), 4.57(\mathrm{dd}, J=7.6,5.0 \mathrm{~Hz}, 1 \mathrm{H}), 4.40(\mathrm{~d}, J=7.3$ $\mathrm{Hz}, 1 \mathrm{H}), 4.20$ (t, $J=6.9 \mathrm{~Hz}, 1 \mathrm{H}), 3.85(\mathrm{~d}, J=13.0 \mathrm{~Hz}, 1 \mathrm{H}), 3.60(\mathrm{~d}, J=12.5 \mathrm{~Hz}, 1 \mathrm{H})$, $3.30(\mathrm{~d}, J=3.0 \mathrm{~Hz}, 1 \mathrm{H}), 3.18(\mathrm{~m}, 1 \mathrm{H}), 1.79(\mathrm{~s}, 1 \mathrm{H}) .{ }^{13} \mathrm{C} \mathrm{NMR}\left(100 \mathrm{MHz}, \mathrm{CDCl}_{3}\right) \delta$ $169.23,155.93,143.89,143.77,141.48,135.05,128.90,128.57,127.97,127.29$, 
125.23, 120.23, 68.02, 67.50, 60.59, 56.64, 54.51, 47.23. HR-ESI-MS (m/z): calcd for $\mathrm{C}_{27} \mathrm{H}_{25} \mathrm{NO}_{6} \mathrm{H}^{+}\left(\mathrm{M}+\mathrm{H}^{+}\right): 460.1682$, found: 460.1745 .

\section{Compound 8:}

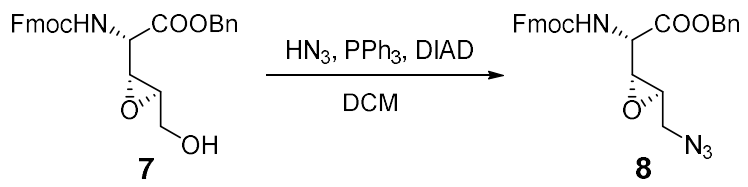

To the solution of compound $7(2.70 \mathrm{~g}, 5.88 \mathrm{mmol})$ and $\mathrm{Ph}_{3} \mathrm{P}(3.09 \mathrm{~g}, 11.79 \mathrm{mmol})$ in dry DCM $(40 \mathrm{~mL})$ was added $\mathrm{HN}_{3}(19.60 \mathrm{~mL}, 29.41 \mathrm{mmol}, 1.5 \mathrm{M})$ and DIAD $(2.31 \mathrm{~mL}$, $11.79 \mathrm{mmol}$ ) at $0^{\circ} \mathrm{C}$. Then the reaction was allowed to warm to room temperature. After stirred at room temperature for $1 \mathrm{~h}$, the reaction mixture was concentrated in vacuo and purified by silica gel flash chromatography $(n$-hexanes/EtOAc $=6: 1)$ to give $2.61 \mathrm{~g}$ of compound 8 as a white solid in $92 \%$ yield. ${ }^{1} \mathrm{H}$ NMR $\left(400 \mathrm{MHz}, \mathrm{CDCl}_{3}\right) \delta 7.76(\mathrm{~d}, J=$ $7.4 \mathrm{~Hz}, 2 \mathrm{H}), 7.57(\mathrm{~d}, J=7.4 \mathrm{~Hz}, 2 \mathrm{H}), 7.48-7.26(\mathrm{~m}, 9 \mathrm{H}), 5.60(\mathrm{~d}, J=7.6 \mathrm{~Hz}, 1 \mathrm{H})$, $5.23(\mathrm{q}, J=12.2 \mathrm{~Hz}, 2 \mathrm{H}), 4.54(\mathrm{~m}, 1 \mathrm{H}), 4.40(\mathrm{~d}, J=7.0 \mathrm{~Hz}, 2 \mathrm{H}), 4.19(\mathrm{t}, J=6.9 \mathrm{~Hz}$, 1H), $3.48(\mathrm{~m}, 1 \mathrm{H}), 3.23(\mathrm{~m}, 3 \mathrm{H}) .{ }^{13} \mathrm{C} \mathrm{NMR}\left(100 \mathrm{MHz}, \mathrm{CDCl}_{3}\right) \delta$ 168.88, 155.85, 143.84, $143.73,141.46,134.90,128.90,128.57,127.96,127.27,125.21,120.21,68.09,67.50$ 55.20, 54.66, 54.39, 50.86, 47.19. HR-ESI-MS (m/z): calcd for $\mathrm{C}_{27} \mathrm{H}_{24} \mathrm{~N}_{4} \mathrm{O}_{5} \mathrm{Na}^{+}(\mathrm{M}+$ $\mathrm{Na}^{+}$): 507.1639, found: 507.1628 .

\section{Compound 10:}



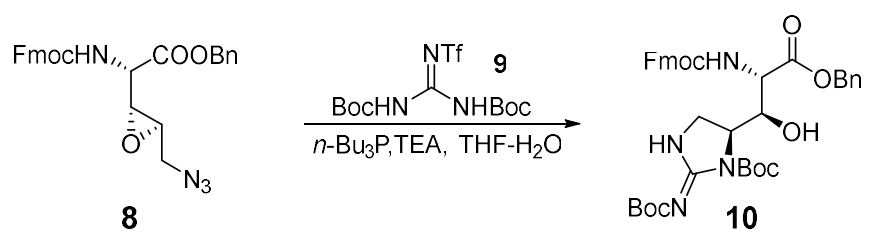

To the solution of compound 8 (564 mg, $1.16 \mathrm{mmol})$, Goodman's reagent 9 (684 mg, $1.74 \mathrm{mmol}), \mathrm{Et}_{3} \mathrm{~N}(167 \mu \mathrm{L}, 1.16 \mathrm{mmol})$ and water $(63 \mu \mathrm{L}, 3.48 \mathrm{mmol})$ in anhydrous THF $(50 \mathrm{~mL})$ was added $n$-Bu $\mathrm{P}(0.34 \mathrm{~mL}, 1.39 \mathrm{mmol})$ at $0^{\circ} \mathrm{C}$. Then the reaction mixture was allowed to warm to room temperature and stirred overnight. After stirred overnight, acetic acid $(60 \mu \mathrm{L}, 1.04 \mathrm{mmol})$ was added and the solvent was removed in vacuo. The resulting residue was purified by silica gel flash chromatography ( $n$ hexanes/EtOAc $=2: 1$ to $5: 4$ ) to give $479 \mathrm{mg}$ of compound $\mathbf{1 0}$ as a white solid in $59 \%$ yield. ${ }^{1} \mathrm{H}$ NMR (400 MHz, $\left.\mathrm{CDCl}_{3}\right) \delta 7.75(\mathrm{~d}, \mathrm{~J}=7.4 \mathrm{~Hz}, 2 \mathrm{H}), 7.58(\mathrm{~d}, \mathrm{~J}=7.2 \mathrm{~Hz}, 2 \mathrm{H})$, $7.45-7.25(\mathrm{~m}, 9 \mathrm{H}), 5.85(\mathrm{~d}, \mathrm{~J}=8.7 \mathrm{~Hz}, 1 \mathrm{H}), 5.28-5.10(\mathrm{~m}, 2 \mathrm{H}), 4.40(\mathrm{~m}, 4 \mathrm{H}), 4.19$ $(\mathrm{m}, 2 \mathrm{H}), 3.82(\mathrm{~d}, \mathrm{~J}=12.0 \mathrm{~Hz}, 1 \mathrm{H}), 3.56(\mathrm{~m}, 1 \mathrm{H}), 1.48(\mathrm{~s}, 9 \mathrm{H}), 1.45(\mathrm{~s}, 9 \mathrm{H}) .{ }^{13} \mathrm{C} \mathrm{NMR}$ $\left(125 \mathrm{MHz}, \mathrm{CDCl}_{3}\right) \delta 170.36,156.94,144.08,143.81,141.47,141.39,135.31,128.74$, $128.62,128.56,127.88,127.26,125.34,125.25,120.12,84.20,81.05,71.09,67.72$, 67.52, 59.28, 57.73, 47.25, 28.31, 28.10. HR-ESI-MS (m/z): calcd for $\mathrm{C}_{38} \mathrm{H}_{44} \mathrm{~N}_{4} \mathrm{O}_{9} \mathrm{H}^{+}$ $\left(\mathrm{M}+\mathrm{H}^{+}\right):$701.3108, found: 701.3211.

\section{Compound S1:}
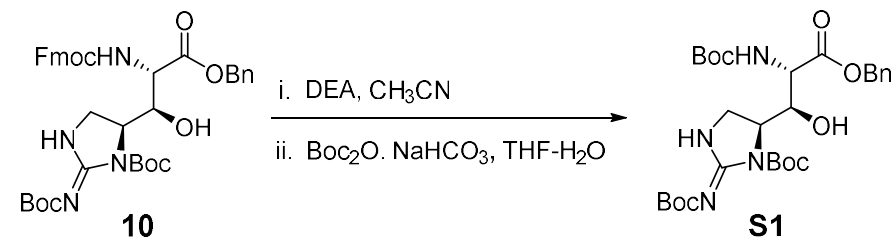

To the solution of compound $\mathbf{1 0}(750 \mathrm{mg}, 1.10 \mathrm{mmol})$ in $\mathrm{CH}_{3} \mathrm{CN}(15 \mathrm{~mL})$ was added 
DEA $(3 \mathrm{~mL})$ at $0^{\circ} \mathrm{C}$. After stirred for $30 \mathrm{~min}$, the solvent was removed by a steam of condensed air and the resulting residue could be used in the next step without further purification.

To the solution of crude product from last step and $\mathrm{NaHCO}_{3}(924 \mathrm{mg}, 11.00 \mathrm{mmol})$ in THF $(15 \mathrm{~mL})$ and water $(15 \mathrm{~mL})$ was added $\mathrm{Boc}_{2} \mathrm{O}(713 \mathrm{mg}, 3.30 \mathrm{mmol})$ at room temperature. After stirred overnight, THF was removed in vacuo. The resulting residue was extracted with EtOAc $(30 \mathrm{~mL} \times 3)$ and purified by silica gel flash chromatography (n-hexanes/EtOAc $=3: 1$ ) to afford $400 \mathrm{mg}$ of compound S1 as a white solid in $75 \%$ yield. ${ }^{1} \mathrm{H}$ NMR (400 MHz, CDCl3) $\delta 7.40-7.30(\mathrm{~m}, 5 \mathrm{H}), 5.54(\mathrm{~d}, J=8.6 \mathrm{~Hz}, 1 \mathrm{H})$, $5.18(\mathrm{~d}, J=3.0 \mathrm{~Hz}, 2 \mathrm{H}), 4.50-4.28(\mathrm{~m}, 2 \mathrm{H}), 4.18(\mathrm{dd}, J=6.0,2.0 \mathrm{~Hz}, 1 \mathrm{H}), 3.88-3.70$ $(\mathrm{m}, 1 \mathrm{H}), 3.59(\mathrm{t}, J=11.1 \mathrm{~Hz}, 1 \mathrm{H}), 1.51(\mathrm{~s}, 9 \mathrm{H}), 1.45(\mathrm{~s}, 9 \mathrm{H}), 1.41(\mathrm{~s}, 9 \mathrm{H}) .{ }^{13} \mathrm{C} \mathrm{NMR}$ $(101 \mathrm{MHz}, \mathrm{CDCl} 3) \delta 170.62,155.49,135.01,128.63,128.49,128.40,83.83,80.30$, 77.27, 72.92, 67.49, 58.30, 56.11, 28.27, 28.17, 28.13. HR-ESI-MS (m/z): calcd for $\mathrm{C}_{28} \mathrm{H}_{42} \mathrm{~N}_{4} \mathrm{O}_{9} \mathrm{H}^{+}\left(\mathrm{M}+\mathrm{H}^{+}\right):$579.2952, found: 579.3019 .

\section{Compound 2:}

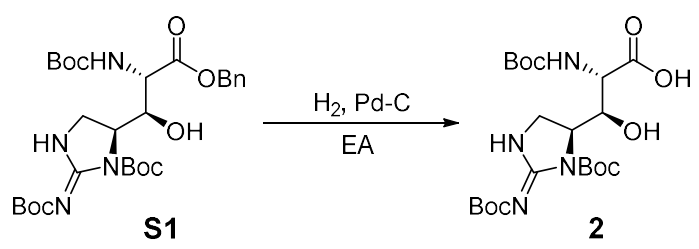

To the solution of compound $\mathbf{S 1}(400 \mathrm{mg}, 0.69 \mathrm{mmol})$ in EA was added $\mathrm{Pd} / \mathrm{C}(40 \mathrm{mg})$ and the reaction mixture was stirred for $2 \mathrm{~h}$ under $\mathrm{H}_{2}$. Upon disappearance of the starting material, $\mathrm{Pd} / \mathrm{C}$ was filtered off through celite and the solvent was removed in vacuo to afford compound $\mathbf{2}$ without further purification. 


\section{ii. Synthesis of $N$-Man- $D$ - $\beta$ hEnd}

\section{Compound 11:}

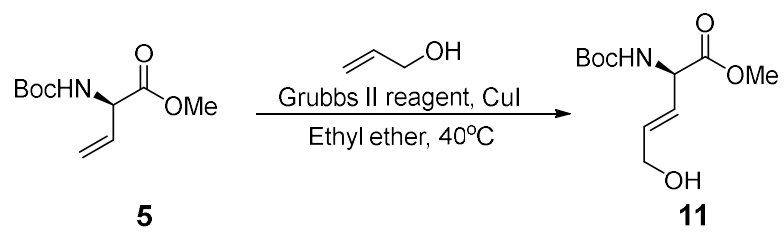

To the solution of compound 5 (12.00 g, $56.00 \mathrm{mmol}), \mathrm{CuI}(2.60 \mathrm{~g}, 14.00 \mathrm{mmol})$ and Grubbs II catalyst $(1.60 \mathrm{~g}, 1.90 \mathrm{mmol})$ in dry diethyl ether $(250 \mathrm{~mL})$ was added allylic alcohol $(8 \mathrm{~mL}, 148.01 \mathrm{mmol})$ with the protection of argon at room temperature. Then the reaction mixture was heated to reflux. After refluxed for $4 \mathrm{~h}$, the reaction mixture was concentrated in vacuo and purified by silica gel flash chromatography (nhexanes/EtOAc $=5: 4)$ to give $11.30 \mathrm{~g}$ of compound $\mathbf{1 1}$ as brown oil in $83 \%$ yield. ${ }^{1} \mathrm{H}$ NMR $\left(500 \mathrm{MHz}, \mathrm{CDCl}_{3}\right) \delta 5.93(\mathrm{dtd}, J=15.6,5.0,1.5 \mathrm{~Hz}, 1 \mathrm{H}), 5.77(\mathrm{dd}, J=15.7,5.8$ $\mathrm{Hz}, 1 \mathrm{H}), 5.42-5.31(\mathrm{~m}, 1 \mathrm{H}), 4.86(\mathrm{t}, J=7.1 \mathrm{~Hz}, 1 \mathrm{H}), 4.22-4.11(\mathrm{~m}, 2 \mathrm{H}), 3.76(\mathrm{~s}, 3 \mathrm{H})$, $2.39(\mathrm{~s}, 1 \mathrm{H}), 1.45(\mathrm{~s}, 10 \mathrm{H}) .{ }^{13} \mathrm{C} \mathrm{NMR}\left(126 \mathrm{MHz}, \mathrm{CDCl}_{3}\right) \delta 171.55,155.26,132.86$, 125.46, 80.39, 62.50, 55.10, 52.80, 28.46. HR-ESI-MS (m/z): calcd for $\mathrm{C}_{11} \mathrm{H}_{19} \mathrm{NO}_{5} \mathrm{H}^{+}$ $\left(\mathrm{M}+\mathrm{H}^{+}\right): 246.1253$, found: 246.1147 .

\section{Compound 12:}

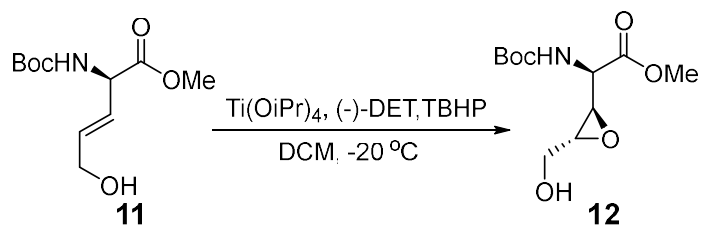


To a solution of 4A molecular sieves $(10 \mathrm{~g})$ in dry DCM $(80 \mathrm{~mL})$ were added (-)-DET $(6.20 \mathrm{~mL}, 36.31 \mathrm{mmol})$ and $\mathrm{Ti}(\mathrm{O} i \mathrm{Pr})_{4}(8.70 \mathrm{~mL}, 29.72 \mathrm{mmol})$ with the protection of argon at $-20^{\circ} \mathrm{C}$. The resulting mixture was continued to stir at $-20^{\circ} \mathrm{C}$. After $30 \mathrm{~min}$, TBHP $(19.8 \mathrm{~mL}, 99.03 \mathrm{mmol})$ was added dropwise. The mixture was stirred at $-20^{\circ} \mathrm{C}$ for another $30 \mathrm{~min}$. Compound 11 (8.0 g, $33.03 \mathrm{mmol})$ in DCM $(15 \mathrm{~mL})$ was then added dropwise and the resulting mixture was kept at $-20^{\circ} \mathrm{C}$ for $8 \mathrm{~h}$. The reaction was diluted with diethyl ether $(100 \mathrm{~mL})$ and quenched with saturated $\mathrm{Na}_{2} \mathrm{SO}_{4}(9.00 \mathrm{~mL})$. The mixture was stirred at room temperature for $3 \mathrm{~h}$ and filtered through celite, the filtrate was subsequently concentrated in vacuo. The resulting residue was purified by silica gel flash chromatography (n-hexanes/EtOAc $=5: 4$ ) to give $8.60 \mathrm{~g}$ of compound $\mathbf{1 2}$ as a colorless oil in $85 \%$ yield. ${ }^{1} \mathrm{H}$ NMR $\left(500 \mathrm{MHz}, \mathrm{CDCl}_{3}\right) \delta 5.23(\mathrm{~d}, J=8.9 \mathrm{~Hz}, 1 \mathrm{H})$, $4.57(\mathrm{dd}, J=9.1,2.4 \mathrm{~Hz}, 1 \mathrm{H}), 3.84(\mathrm{dd}, J=12.9,2.5 \mathrm{~Hz}, 1 \mathrm{H}), 3.73(\mathrm{~s}, 3 \mathrm{H}), 3.60$ (dd, $J$ $=12.9,4.2 \mathrm{~Hz}, 1 \mathrm{H}), 3.41(\mathrm{~d}, J=2.4 \mathrm{~Hz}, 1 \mathrm{H}), 3.08-3.00(\mathrm{~m}, 1 \mathrm{H}), 2.81-2.67(\mathrm{~m}, 1 \mathrm{H})$, $1.36(\mathrm{~s}, 9 \mathrm{H}) .{ }^{13} \mathrm{C} \mathrm{NMR}\left(126 \mathrm{MHz}, \mathrm{CDCl}_{3}\right) \delta 170.56,155.68,80.60,60.74,55.66,54.62$, 52.95, 52.62, 28.33. HR-ESI-MS (m/z): calcd for $\mathrm{C}_{11} \mathrm{H}_{19} \mathrm{NO}_{6} \mathrm{H}^{+}\left(\mathrm{M}+\mathrm{H}^{+}\right)$: 262.1212, found: 262.1343 .

\section{Compound S2:}

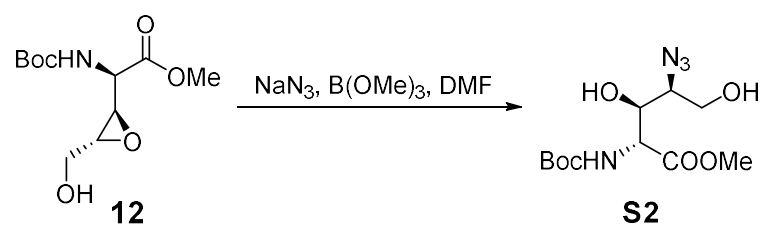

To the solution of compound $12(3.51 \mathrm{~g}, 13.4 \mathrm{mmol})$ and $\mathrm{NaN}_{3}(2.60 \mathrm{~g}, 40.2 \mathrm{mmol})$ in 
anhydrous DMF $(60 \mathrm{~mL})$ was added $\mathrm{B}(\mathrm{OMe})_{3}(5.50 \mathrm{~g}, 53.6 \mathrm{mmol})$ at room temperature, and the temperature of the reaction was raised to $50^{\circ} \mathrm{C}$ and stirred for $4 \mathrm{~h}$. Then, the reaction was quenched by saturated $\mathrm{NH}_{4} \mathrm{Cl}(100 \mathrm{~mL})$ and diluted with ethyl acetate $(500 \mathrm{~mL})$. The reaction mixture was washed with saturated $\mathrm{NH}_{4} \mathrm{Cl}(100 \mathrm{~mL} \times 2)$ and brine $(100 \mathrm{~mL})$. The organic phase was dried over $\mathrm{Na}_{2} \mathrm{SO}_{4}$ and concentrated in vacuo. The resulting residue was purified by silica gel flash chromatography (n-hexane/EtOAc $=1: 1)$ to give $3.12 \mathrm{~g}$ of compound $\mathbf{S} 2$ as colorless oil in $78 \%$ yield. ${ }^{1} \mathrm{H}$ NMR $(500 \mathrm{MHz}$, $\left.\mathrm{CDCl}_{3}\right) \delta 5.59(\mathrm{~d}, J=9.8 \mathrm{~Hz}, 1 \mathrm{H}), 4.77(\mathrm{~d}, J=6.2 \mathrm{~Hz}, 1 \mathrm{H}), 4.64(\mathrm{~d}, J=9.8 \mathrm{~Hz}, 1 \mathrm{H})$, 4.20-4.06 (m, 1H), 4.05-3.85 (m, 2H), $3.76(\mathrm{~s}, 3 \mathrm{H}), 3.60-3.42(\mathrm{~m}, 2 \mathrm{H}), 1.46(\mathrm{~s}, 9 \mathrm{H})$.

${ }^{13} \mathrm{C} \mathrm{NMR}\left(126 \mathrm{MHz}, \mathrm{CDCl}_{3}\right) \delta 171.94,156.24,80.27,70.92,63.32,62.57,55.72,52.56$, 29.38. HR-ESI-MS (m/z): calcd for $\mathrm{C}_{11} \mathrm{H}_{20} \mathrm{~N}_{4} \mathrm{O}_{6} \mathrm{H}^{+}\left(\mathrm{M}+\mathrm{H}^{+}\right)$: 305.1383, found: 305.1455 .

\section{Compound S3:}
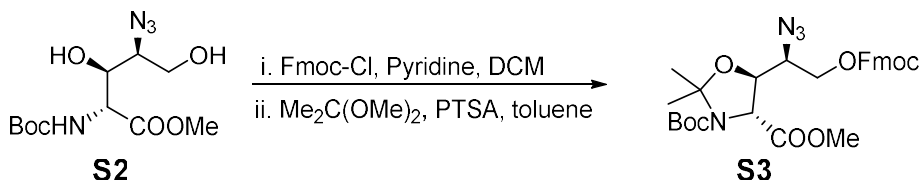

To the solution of compound S2 (3.12 g, $5.48 \mathrm{mmol})$ and Fmoc-Cl $(1.49 \mathrm{~g}, 5.76 \mathrm{mmol})$ in anhydrous DCM $(10 \mathrm{~mL})$ was added pyridine $(0.57 \mathrm{~mL}, 7.12 \mathrm{mmol})$ at $0^{\circ} \mathrm{C}$. The reaction was warmed to room temperature and stirred for $2 \mathrm{~h}$. The reaction mixture was concentrated in vacuo. The resulting residue was purified by silica gel flash chromatography (n-hexane/EtOAc $=3: 1)$ to afford $3.31 \mathrm{~g}$ of compound $\mathbf{1 3}$ as colorless 
oil in $70 \%$ yield. ${ }^{1} \mathrm{H}$ NMR $\left(500 \mathrm{MHz}, \mathrm{CDCl}_{3}\right) \delta 7.79(\mathrm{~d}, J=7.5 \mathrm{~Hz}, 2 \mathrm{H}), 7.64(\mathrm{~d}, J=$ $7.5 \mathrm{~Hz}, 2 \mathrm{H}), 7.44(\mathrm{t}, J=7.5 \mathrm{~Hz}, 2 \mathrm{H}), 7.35$ (t, $J=7.5 \mathrm{~Hz}, 2 \mathrm{H}), 5.41-5.28(\mathrm{~m}, 1 \mathrm{H}), 4.73$ $-4.67(\mathrm{~m}, 1 \mathrm{H}), 4.73-4.65(\mathrm{~m}, 1 \mathrm{H}), 4.52-4.48(\mathrm{~m}, 1 \mathrm{H}), 4.46(\mathrm{~d}, J=7.6 \mathrm{~Hz}, 2 \mathrm{H}), 4.30$ (t, $J=7.5 \mathrm{~Hz}, 1 \mathrm{H}), 4.06(\mathrm{~d}, J=10.0 \mathrm{~Hz}, 1 \mathrm{H}), 3.80(\mathrm{~s}, 3 \mathrm{H}), 3.70(\mathrm{~s}, 1 \mathrm{H}), 3.46(\mathrm{~s}, 1 \mathrm{H})$, $1.50(\mathrm{~s}, 9 \mathrm{H}) .{ }^{13} \mathrm{C} \mathrm{NMR}\left(126 \mathrm{MHz}, \mathrm{CDCl}_{3}\right) \delta 171.40,155.20,143.12,141.27,127.95$, $127.21,125.16,120.07,80.86,70.42,67.42,61.17,55.40,52.81,46.61,28.22$.

Catalytic amount of PTSA ( $390 \mathrm{mg}, 2.05 \mathrm{mmol})$ was added to the solution of compound $13(2.62 \mathrm{~g}, 4.10 \mathrm{mmol})$ and 2,2-dimethoxypropane $(10.00 \mathrm{~mL}, 82.00 \mathrm{mmol})$ in dry Toluene $(10 \mathrm{~mL})$, and the reaction mixture was stirred at $50^{\circ} \mathrm{C}$ for $24 \mathrm{~h}$. The reaction was then quenched with $\mathrm{Et}_{3} \mathrm{~N}(0.30 \mathrm{~mL}, 2.05 \mathrm{mmol})$ and concentrated in vacuo. The resulting residue was purified by silica gel flash chromatography $(\mathrm{n}$-hexane/EtOAc $=$ 5:1) to afford compound $\mathbf{S 3} 2.22 \mathrm{~g}$ in $62 \%$ yield. ${ }^{1} \mathrm{H}$ NMR (500 MHz, $\mathrm{CDCl}_{3}$ ) Signals derived from rotamers $(1: 2) \delta 7.75(\mathrm{~d}, J=7.6 \mathrm{~Hz}, 2 \mathrm{H}), 7.60(\mathrm{ddd}, J=7.5,2.1,1.1 \mathrm{~Hz}$, 2H), $7.39(\mathrm{t}, J=7.4 \mathrm{~Hz}, 2 \mathrm{H}), 7.33-7.29(\mathrm{~m}, 2 \mathrm{H}), 4.55-4.40(\mathrm{~m}, 2 \mathrm{H}$ from minor and major), $4.38(\mathrm{~d}, J=6.3 \mathrm{~Hz}, 1 \mathrm{H}), 4.37-4.30(\mathrm{~m}, 1 \mathrm{H}), 4.28-4.22(\mathrm{~m}, 2 \mathrm{H}), 4.18(\mathrm{t}, J=$ $6.0 \mathrm{~Hz}, 1 \mathrm{H}), 3.96-3.88(\mathrm{~m}, 1 \mathrm{H}), 3.75(\mathrm{~s}, 3 \mathrm{H}), 1.68(\mathrm{~s}, 2 \mathrm{H}$ from major), $1.64-1.58(\mathrm{~m}$, $4 \mathrm{H}$ from minor and major), 1.49 (s, $3 \mathrm{H}$ from minor), 1.42 (s, $6 \mathrm{H}$ from major). ${ }^{13} \mathrm{C}$ NMR $\left(126 \mathrm{MHz}, \mathrm{CDCl}_{3}\right) \delta 171.22,171.15,170.75,154.69,151.86,150.97,143.26,143.21$ $141.38,141.36,128.10,128.05,127.30,125.22,120.19,96.57,95.84,81.50,81.02$, $77.48,77.43,77.23,76.97,76.84,70.36,66.56,66.41,61.54,61.34,61.13,52.78,52.61$, 46.72, 28.29, 28.21, 26.79, 25.35, 24.34. HR-ESI-MS (m/z): calcd for $\mathrm{C}_{29} \mathrm{H}_{34} \mathrm{~N}_{4} \mathrm{O}_{8} \mathrm{Na}^{+}$ 
$\left(\mathrm{M}+\mathrm{Na}^{+}\right): 589.2377$, found: 589.2270 .

\section{Compound 14:}

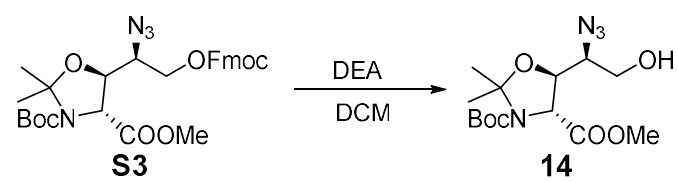

To the above compound $\mathbf{S 3}$ in DCM $(100 \mathrm{~mL})$ was added DEA $(10 \mathrm{~mL})$ and the reaction mixture was stirred for $2 \mathrm{~h}$. Upon the disappearance of starting material, the reaction mixture was concentrated to dryness in vacuo. The resulting residue was purified by silica gel flash chromatography (n-hexane/EtOAc $=3: 1)$ to give $1.31 \mathrm{~g}$ of compound 14 as colorless oil in $99 \%$ yield. ${ }^{1} \mathrm{H}$ NMR (400 MHz, $\left.\mathrm{CDCl}_{3}\right)$ Signals derived from rotamers (1:2) $\delta 4.47(\mathrm{~d}, J=6.5 \mathrm{~Hz}, 0.3 \mathrm{H}$ from minor), 4.37 (d, $J=6.5 \mathrm{~Hz}, 0.6 \mathrm{H}$ from major), $4.22(\mathrm{t}, J=5.0 \mathrm{~Hz}, 1 \mathrm{H}), 3.80-3.70(\mathrm{~m}, 6 \mathrm{H}), 1.67(\mathrm{~s}, 2 \mathrm{H}$ from major), $1.62(\mathrm{~s}$, $1 \mathrm{H}$ from minor), $1.60(\mathrm{~s}, 2 \mathrm{H}$ from major), $1.58(\mathrm{~s}, 1 \mathrm{H}$ from minor), $1.49(\mathrm{~s}, 3 \mathrm{H}$ from minor), 1.42 (s, $6 \mathrm{H}$ from major). ${ }^{13} \mathrm{C} \mathrm{NMR}\left(126 \mathrm{MHz}, \mathrm{CDCl}_{3}\right) \delta 171.81,171.33,152.02$, $151.09,96.25,95.56,81.60,81.09,77.73,77.32,64.60,64.58,61.90,61.26,61.20$, 52.83, 52.68, 28.40, 28.34, 27.89, 26.77, 25.24, 24.32. HR-ESI-MS (m/z): calcd for $\mathrm{C}_{14} \mathrm{H}_{24} \mathrm{~N}_{4} \mathrm{O}_{6} \mathrm{Na}^{+}\left(\mathrm{M}+\mathrm{Na}^{+}\right): 367.1696$, found: 367.1591 .

\section{Compound 17:}




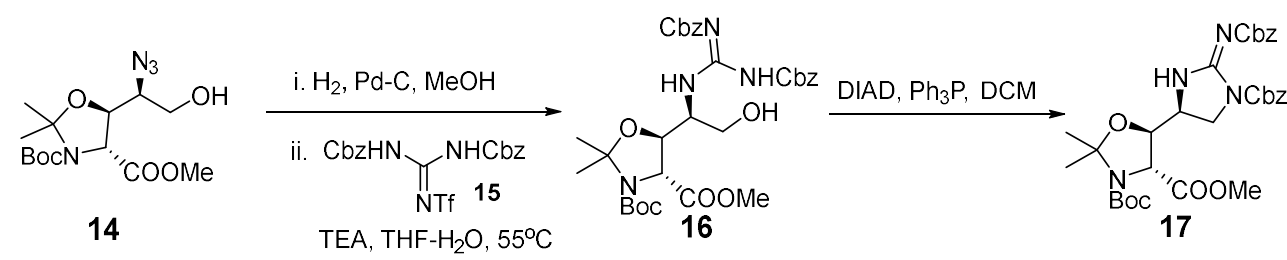

To the solution of compound $14(1.31 \mathrm{~g}, 3.82 \mathrm{mmol})$ in methanol, $\mathrm{Pd} / \mathrm{C}(130 \mathrm{mg})$ was added and the reaction was stirred for $2 \mathrm{~h}$ under $\mathrm{H}_{2}$. Upon disappearence of the starting material, $\mathrm{Pd} / \mathrm{C}$ was filtered off through celite and the solvent was removed in vacuo. The resulting residue can be used in the next step without further purification.

To the solution of the crude compound got from last step and guanidination reagent $\mathbf{1 5}$ $(3.51 \mathrm{~g}, 7.64 \mathrm{mmol})$ in water $(1 \mathrm{~mL})$ and dioxane $(35 \mathrm{~mL})$ was added $\mathrm{Et}_{3} \mathrm{~N}(2.85 \mathrm{~mL}$, $19.5 \mathrm{mmol}$ ). The reaction mixture was stirred overnight at room temperature. Upon completion of the reaction, the reaction mixture was concentrated to dryness in vacuo. The resulting residue was purified by silica gel flash chromatography ((nhexane/EtOAc $=5: 1$ to $3: 1)$ to afford $1.81 \mathrm{~g}$ of compound $\mathbf{1 6}$ as while solid in $75 \%$ yield over 2 steps.

To the solution of compound $\mathbf{1 6}(1.81 \mathrm{~g}, 2.91 \mathrm{mmol})$ and $\mathrm{Ph}_{3} \mathrm{P}(1.1 \mathrm{~g}, 4.42 \mathrm{mmol})$ in anydrous DCM $(20 \mathrm{~mL})$ was added DIAD $(0.82 \mathrm{~mL}, 3.81 \mathrm{mmol})$ and the reaction mixture was stirred at room temperature for $2 \mathrm{~h}$ with the protection of argon. Upon the disappearance of starting materials, the reaction mixture was concentrated to dryness in vacuo. The resulting residue was purified by silica gel flash chromatography (nhexane/EtOAc $=5: 2$ ) to give $1.32 \mathrm{~g}$ of compound $\mathbf{1 7}$ as while solid in $75 \%$ yield. ${ }^{1} \mathrm{H}$ NMR (500 MHz, Acetone) Signals derived from rotamers $(1: 2) \delta 7.60-7.52(\mathrm{~m}, 2 \mathrm{H})$, $7.42(\mathrm{~d}, J=7.1 \mathrm{~Hz}, 2 \mathrm{H}), 7.39-7.26(\mathrm{~m}, 6 \mathrm{H}), 5.27(\mathrm{~s}, 2 \mathrm{H}), 5.13(\mathrm{~s}, 2 \mathrm{H}), 4.35-4.25(\mathrm{~m}$, $3 \mathrm{H}), 4.12(\mathrm{dd}, J=10.9,9.2 \mathrm{~Hz}, 1 \mathrm{H}), 3.94(\mathrm{dd}, J=11.0,4.7 \mathrm{~Hz}, 1 \mathrm{H}), 3.73$ (s, 2H from 
major), 3.68 (s, $1 \mathrm{H}$ from minor), $2.05(\mathrm{p}, J=2.2 \mathrm{~Hz}, 1 \mathrm{H}), 1.57(\mathrm{~d}, J=4.1 \mathrm{~Hz}, 3 \mathrm{H}), 1.55$

(s, 3H), 1.46 (s, 3H from minor), 1.37 (s, 6H from major). ${ }^{13} \mathrm{C}$ NMR (126 MHz, Acetone)

$\delta 171.77,171.06,170.95,151.76,151.54,138.31,136.98,129.20,129.15,129.12$, $129.05,128.75,128.56,128.53,128.51,128.49,98.62,96.43,95.92,81.33,80.86$, $79.64,79.08,68.35,67.56,62.41,60.53,52.90,52.73,46.44,28.41,28.37,28.32,28.02$, 26.66, 25.42, 24.37, 21.10, 20.82, 17.56. HR-ESI-MS (m/z): calcd for $\mathrm{C}_{31} \mathrm{H}_{38} \mathrm{~N}_{4} \mathrm{O}_{9} \mathrm{H}^{+}$ $\left(\mathrm{M}+\mathrm{H}^{+}\right): 611.2639$, found: 611.2733 .

\section{Compound 3:}

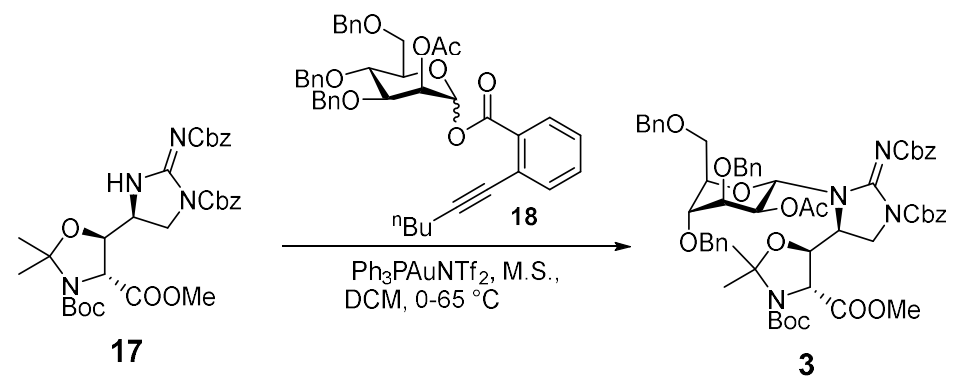

Substrate 17 (1.32 g, $2.11 \mathrm{mmol})$ and sugar donor $\mathbf{1 8}(2.33 \mathrm{~g}, 3.21 \mathrm{mmol})$ were stirred

for $1 \mathrm{~h}$ in dry toluene with pre-activated molecular sieves $(3.00 \mathrm{~g})$ under the protection of argon. Then, catalytic amount of $\mathrm{Ph}_{3} \mathrm{PAuNTf}_{2}-0.5$ Toluene (352 mg, 0.42mmol) was added to the reaction mixture at $0^{\circ} \mathrm{C}$. The reaction was then raised to $65^{\circ} \mathrm{C}$ and stirred for $12 \mathrm{~h}$. Then the reaction mixture was filtered through celite and the filtrate was concentrated by vacuo. The resulting residue was purified by silica gel flash chromatography (n-hexane/EtOAc $=3: 1-1: 1)$ to afford $1.37 \mathrm{~g}$ of compound 3 as white sticky powder in $61 \%$ yield. ${ }^{1} \mathrm{H}$ NMR (500 MHz, DMSO, 347K) $\delta 7.45-7.14(\mathrm{~m}, 25 \mathrm{H})$, 
$5.72(\mathrm{~d}, J=9.0 \mathrm{~Hz}, 1 \mathrm{H}), 5.24-5.13(\mathrm{~m}, 2 \mathrm{H}), 5.03(\mathrm{~d}, J=12.4 \mathrm{~Hz}, 1 \mathrm{H}), 4.98-4.82(\mathrm{~m}$,

2H), $4.61-4.52(\mathrm{~m}, 3 \mathrm{H}), 4.52-4.36(\mathrm{~m}, 3 \mathrm{H}), 4.26-4.10(\mathrm{~m}, 4 \mathrm{H}), 4.08-3.92(\mathrm{~m}$,

$3 \mathrm{H}), 3.81-3.71(\mathrm{~m}, 2 \mathrm{H}), 3.65(\mathrm{dd}, J=11.0,4.7 \mathrm{~Hz}, 1 \mathrm{H}), 3.55(\mathrm{~s}, 3 \mathrm{H}), 1.96(\mathrm{~s}, 3 \mathrm{H})$,

$1.43-1.27(\mathrm{~m}, 15 \mathrm{H}) .{ }^{13} \mathrm{C}$ NMR $(126 \mathrm{MHz}, \mathrm{DMSO}) \delta 169.87,158.98,152.69,151.47$

$138.92,138.52,138.29,137.42,135.82,128.95,128.90,128.83,128.80,128.74$,

$128.71,128.35,128.33,128.25,128.20,128.18,128.15,127.98,127.88,95.96,80.80$,

$78.12,77.72,76.89,75.63,74.61,73.23,72.83,72.13,68.66,68.40,68.13,67.13,60.79$,

53.02, 52.64, 46.33, 28.44, 21.07. HR-ESI-MS (m/z): calcd for $\mathrm{C}_{74} \mathrm{H}_{74} \mathrm{~N}_{4} \mathrm{O}_{14} \mathrm{H}^{+}(\mathrm{M}+$ $\mathrm{H}^{+}$): 1085.4681, found: 1085.4750 .

\section{Compound S4:}

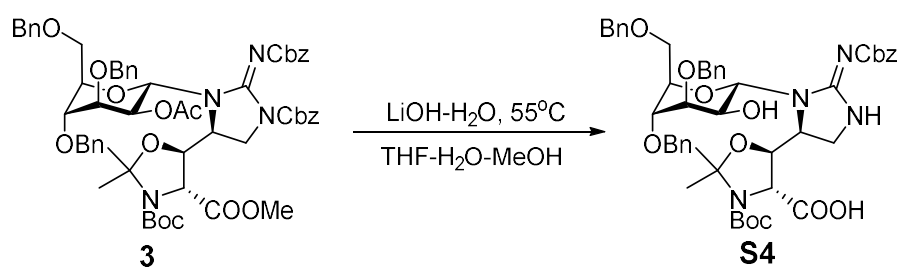

To the solution of compound 3 (500 mg, $0.46 \mathrm{mmol})$ in THF $(10 \mathrm{~mL}), \mathrm{MeOH}(10 \mathrm{~mL})$ and water $(10 \mathrm{~mL})$ was added $\mathrm{LiOH} \cdot \mathrm{H}_{2} \mathrm{O}(145 \mathrm{mg}, 3.5 \mathrm{mmol})$, and the reaction was stirred at $55^{\circ} \mathrm{C}$ for $2 \mathrm{~h}$. Then the reaction was diluted with EtOAc $(150 \mathrm{~mL})$ and washed with $0.1 \mathrm{M}$ aq. $\mathrm{HCl}$, water and brine. The organic layer was dried over anhydrous $\mathrm{Na}_{2} \mathrm{SO}_{4}$ and concentrated with reduced pressure to give compound $\mathbf{S} 4$ as colorless syrup. The carboxylic acid product could be used in the next amide coupling reaction without further purification. 


\section{iii. Synthesis of Boc- $\beta$ MePhe-OH}

Boc- $\beta$ MePhe-OH was prepared according to the literature ${ }^{[1]}$. The NMR spectrum we got is the same as the reported one. ${ }^{[1]}$

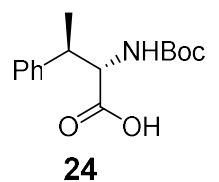

${ }^{1} \mathrm{H}$ NMR (500 MHz, DMSO) $\delta 7.40-7.06(\mathrm{~m}, 5 \mathrm{H}), 6.63(\mathrm{~s}, 1 \mathrm{H}), 4.19(\mathrm{dd}, J=9.1,6.9$ $\mathrm{Hz}, 1 \mathrm{H}), 3.21(\mathrm{~d}, J=7.1 \mathrm{~Hz}, 1 \mathrm{H}), 1.34(\mathrm{~s}, 9 \mathrm{H}), 1.24(\mathrm{~d}, J=7.2 \mathrm{~Hz}, 3 \mathrm{H}) .{ }^{13} \mathrm{C} \mathrm{NMR}(101$ MHz, DMSO) $\delta 173.44,156.07,143.39,128.55,128.14,126.89,78.57,59.72,41.02$, 28.64, 17.11. HR-ESI-MS (m/z): calcd for $\mathrm{C}_{15} \mathrm{H}_{21} \mathrm{NO}_{4} \mathrm{Na}^{+}\left(\mathrm{M}+\mathrm{Na}^{+}\right)$: 302.1471, found: 302.1359.

\section{iv. Synthesis of tripeptide}

\section{Compound S5:}

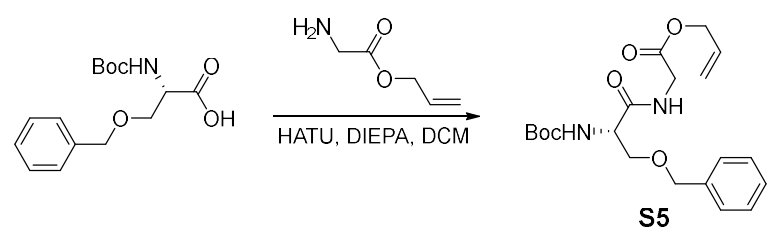

To the solution of Boc-Ser(Bn)-OH (4.11 g, $13.70 \mathrm{mmol})$, HATU (8.62 g, $22.80 \mathrm{mmol})$ and DIEPA $(7.83 \mathrm{~mL}, 45.61 \mathrm{mmol})$ in DCM $(20 \mathrm{~mL})$ was added H-Gly-OAllyl $(1.32 \mathrm{~g}$, $11.41 \mathrm{mmol})$. the reaction mixture was then stirred overnight at room temperature. When the TLC plate showed a complete conversion, the solvent was removed in vacuo 
and the resulting residue was extracted by ethyl acetate, washed with water and dried over anhydrous sodium sulfate. After rotary evaporation of volatiles, the residue was purified by silica gel flash chromatography $($ EtOAc/n-hexane $=1: 5)$ to obtain dipeptide S5 as a colorless oil (3.5 g, 80\% yield). ${ }^{1} \mathrm{H}$ NMR (500 MHz, $\left.\mathrm{CDCl}_{3}\right) \delta 7.35-7.14(\mathrm{~m}$, $5 \mathrm{H}), 5.81(\mathrm{ddt}, J=16.4,10.6,5.8 \mathrm{~Hz}, 1 \mathrm{H}), 5.61(\mathrm{~s}, 1 \mathrm{H}), 5.24(\mathrm{dq}, J=17.2,1.5 \mathrm{~Hz}, 1 \mathrm{H})$, $5.26(\mathrm{dt}, J=10.4,1.3 \mathrm{~Hz}, 1 \mathrm{H}), 4.55(\mathrm{dt}, J=5.8,1.4 \mathrm{~Hz}, 2 \mathrm{H}), 4.50-4.42(\mathrm{~m}, 2 \mathrm{H}), 4.35$ (s, 1H), $4.10(\mathrm{~d}, J=5.3 \mathrm{~Hz}, 2 \mathrm{H}), 3.89(\mathrm{dd}, J=9.9,4.5 \mathrm{~Hz}, 1 \mathrm{H}), 3.67(\mathrm{dd}, J=9.6,5.9$ $\mathrm{Hz}, 1 \mathrm{H}), 1.38$ (s, 9H). ${ }^{13} \mathrm{C}$ NMR $\left(101 \mathrm{MHz}, \mathrm{CDCl}_{3}\right) \delta 170.63,169.20,155.57,137.42$, $131.45,128.50,127.94,127.84,119.04,73.47,69.68,66.05,53.90,41.45,28.30$. HRESI-MS (m/z): calcd for $\mathrm{C}_{20} \mathrm{H}_{28} \mathrm{~N}_{2} \mathrm{O}_{6} \mathrm{Na}^{+}\left(\mathrm{M}+\mathrm{Na}^{+}\right)$: 415.1947, found: 415.1836 .

\section{Compound 19:}

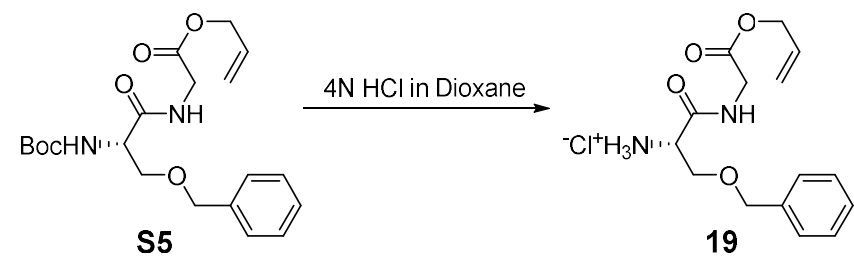

To the compound S5 (504 mg, $1.29 \mathrm{mmol}$ ) was added $5 \mathrm{~mL}$ 4M HCl-Dioxane solution and stir at room temperature for $1 \mathrm{~h}$. Upon the disappearance of the starting material, the reaction mixture was concentrated in vacuo to dryness, the resulting residue could be used for another amine coupling without further purification.

\section{Compound 20:}




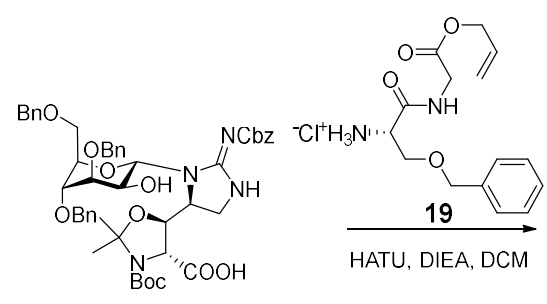

S4

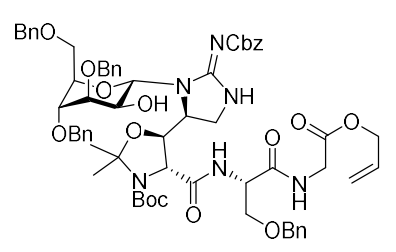

20

To a solution of compound S4 (obtained from $0.52 \mathrm{mmol}$ of compound 3), HATU (500 $\mathrm{mg}, 1.30 \mathrm{mmol})$ and DIPEA $(508 \mu \mathrm{L}, 2.60 \mathrm{mmol})$ in DCM $(30 \mathrm{~mL})$ was added compound 19 (375 $\mathrm{mg}, 1.30 \mathrm{mmol} \mathrm{mmol})$. the reaction mixture was then stirred overnight at room temperature. When the TLC plate showed a complete conversion of the starting material, the reaction mixture was diluted with DCM, washed with $0.5 \mathrm{M}$ aq. $\mathrm{HCl}$ and dried over anhydrous sodium sulfate. After rotary evaporation of volatiles, the residue was purified by silica gel flash chromatography (EtOAc : $n$-hexane $=1: 3$ to 1:1) to obtain tripeptide $\mathbf{2 0}$ as a colorless oil (330 mg, 75\% yield over two steps). ${ }^{1} \mathrm{H}$ NMR (500 MHz, DMSO) $\delta 8.44(\mathrm{~s}, 1 \mathrm{H}), 8.28(\mathrm{~s}, 2 \mathrm{H}), 7.39-7.12(\mathrm{~m}, 25 \mathrm{H}), 5.89$ (ddt, $J=17.2,10.8,5.4 \mathrm{~Hz}, 1 \mathrm{H}), 5.46(\mathrm{~d}, J=8.9 \mathrm{~Hz}, 1 \mathrm{H}), 5.31(\mathrm{dq}, J=17.3,1.8 \mathrm{~Hz}, 1 \mathrm{H})$, $5.20(\mathrm{dq}, J=10.5,1.4 \mathrm{~Hz}, 1 \mathrm{H}), 5.08-4.94(\mathrm{~m}, 2 \mathrm{H}), 4.72-4.61(\mathrm{~m}, 2 \mathrm{H}), 4.61-4.51$ $(\mathrm{m}, 5 \mathrm{H}), 4.49-4.35(\mathrm{~m}, 6 \mathrm{H}), 4.33-4.20(\mathrm{~m}, 2 \mathrm{H}), 4.19-4.08(\mathrm{~m}, 2 \mathrm{H}), 4.02-3.80(\mathrm{~m}$, $3 \mathrm{H}), 3.80-3.48(\mathrm{~m}, 7 \mathrm{H}), 1.55(\mathrm{~d}, J=6.3 \mathrm{~Hz}, 6 \mathrm{H}), 1.35(\mathrm{~s}, 9 \mathrm{H}) .{ }^{13} \mathrm{C}$ NMR $(126 \mathrm{MHz}$, DMSO) $\delta 170.07,169.62,169.29,164.76,163.19,138.96,138.90,138.66,138.58$, $138.20,132.77,128.70,128.58,128.56,128.46,128.03,127.95,127.91,127.87$, $127.82,127.79,127.77,127.73,127.65,127.58,95.11,80.07,78.83,75.84,75.20$, $72.90,72.87,72.75,72.64,71.39,70.20,69.14,66.27,65.17,61.63,55.15,42.08,41.40$ 41.33, 28.43, 26.99, 24.77. HR-ESI-MS (m/z): calcd for $\mathrm{C}_{64} \mathrm{H}_{76} \mathrm{~N}_{6} \mathrm{O}_{15} \mathrm{H}^{+}\left(\mathrm{M}+\mathrm{H}^{+}\right)$: 
1169.5369, found: 1169.5452 .

\section{Compound 21:}

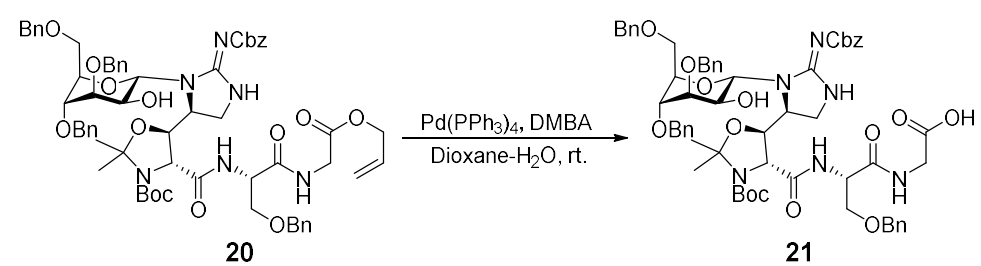

To a solution of compound $\mathbf{2 0}(330 \mathrm{mg}, 28.2 \mu \mathrm{mol})$ in dioxane $(30 \mathrm{~mL})$ and water $(10$ $\mathrm{mL})$ was added $\mathrm{Pd}\left(\mathrm{PPh}_{3}\right)_{4}(65 \mathrm{mg}, 5.7 \mu \mathrm{mol})$ and 1,3-dimethylbarbituric acid (DMBA, $44 \mathrm{mg}, 28.2 \mu \mathrm{mol})$. The resulting orange solution was stirred at room temperature for 2 h. After disappearance of the starting material, dioxane was removed by a steam of condensed air. The resulting solution was diluted with EtOAc $(50 \mathrm{~mL})$ and washed thoroughly with $0.1 \mathrm{M}$ aq. $\mathrm{HCl}$, water and brine. The residue after concentration in vacuo can be used for next step without further purification.

\section{Boc-SPPS and total synthesis of mannopeptimycin $\beta$}

\section{Resin linked peptide 23:}




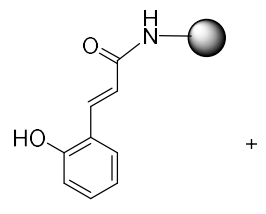

S6
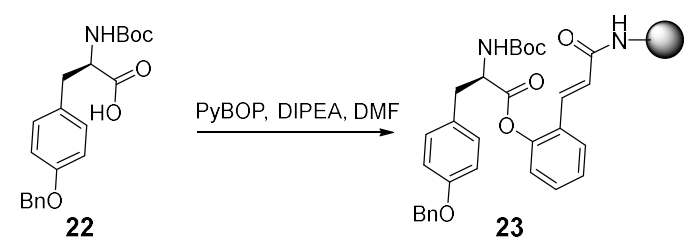

The 2'-hydroxy cinnamic acid modified Aminomethyl resin was prepared according to the literature ${ }^{[3]}$. The loading of the resin was determined by the mass difference to be $0.56 \mathrm{mmol} / \mathrm{g}$. Then, a solution of $20 \%$ piperidine in DMF $(5 \mathrm{~mL})$ was added to the prepared resin $(150 \mathrm{mg}, 0.084 \mathrm{mmol})$ and the mixture was gently agitated for $1 \mathrm{~h}$ to remove the acetyl group and gave $\mathbf{S 6}$ as product. The solvent was drained and the resin was washed with DMF (10 mL x 3). A solution of the Boc-D-Tyr(OBn)-OH (125 mg. $0.336 \mathrm{mmol})$, PyBOP (175 mg, $0.336 \mathrm{mmol}$.) and DIPEA (117 $\mu \mathrm{L}, 0.672 \mathrm{mmol}$.) in anhydrous DMF ( $5 \mathrm{~mL}$ ) was added to the resin. The mixture was gently agitated for 12 h. Then the solvent was drained and the resin was washed with DMF $(10 \mathrm{~mL} \times 3)$, $\mathrm{CH}_{2} \mathrm{Cl}_{2}(10 \mathrm{~mL} \times 3)$ and DMF (10 mL x 3).

\section{Resin linked peptide S7:}
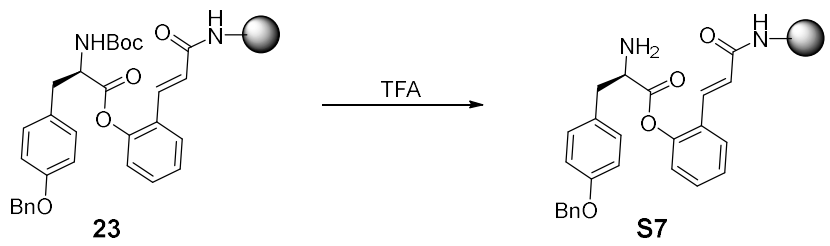

The Boc group in $\mathbf{2 3}$ was removed with neat TFA ( $2 \times 5 \mathrm{~min})$ followed by sequential washing with $\mathrm{CH}_{2} \mathrm{Cl}_{2}(10 \mathrm{~mL} \times 3)$, iso-propanol $(10 \mathrm{~mL} \times 3)$, DMF $(10 \mathrm{~mL} \times 3)$ and $\mathrm{CH}_{2} \mathrm{Cl}_{2}(10 \mathrm{~mL} \times 3)$. 


\section{Resin linked peptide 25:}
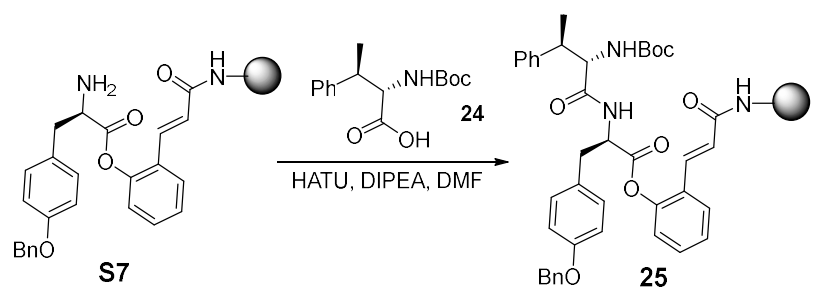

A solution of the compound 24 (47 mg. $0.168 \mathrm{mmol})$, HATU (64 mg, $0.168 \mathrm{mmol}$.) and DIPEA (59 $\mu \mathrm{L}, 0.336 \mathrm{mmol}$.) in anhydrous DMF $(5 \mathrm{~mL})$ was added to the resin. The mixture was gently agitated for $45 \mathrm{~min}$. Then the solvent was drained and the resin was washed with DMF (10 mL x 3), $\mathrm{CH}_{2} \mathrm{Cl}_{2}(10 \mathrm{~mL} \times 3)$ and DMF (10 mL x 3).

\section{Resin linked peptide S8:}

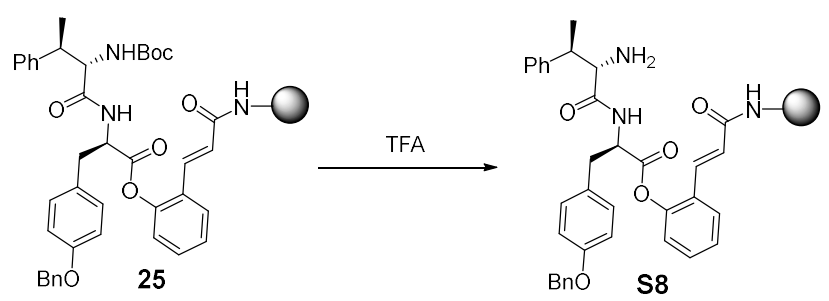

The Boc group in 25 was removed with neat TFA $(2 \times 5 \mathrm{~min})$ followed by sequential washing with $\mathrm{CH}_{2} \mathrm{Cl}_{2}(10 \mathrm{~mL} \times 3)$, iso-propanol $(10 \mathrm{~mL} \times 3)$, DMF $(10 \mathrm{~mL} \times 3)$ and $\mathrm{CH}_{2} \mathrm{Cl}_{2}(10 \mathrm{~mL} \times 3)$.

\section{Resin linked peptide 26:}



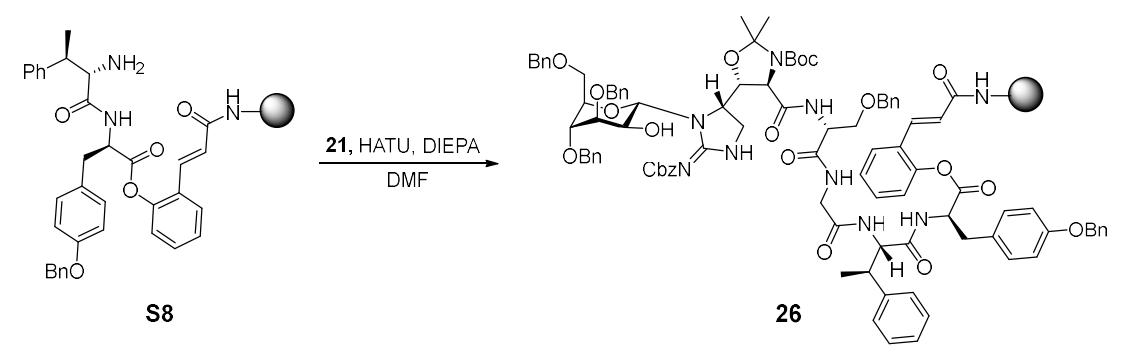

A solution of tripeptide 21 (190 mg. $0.168 \mathrm{mmol})$, HATU (64 mg, $0.168 \mathrm{mmol}$.) and DIPEA (59 $\mu \mathrm{L}, 0.336 \mathrm{mmol}$.) in anhydrous DMF ( $5 \mathrm{~mL})$ was added to the resin. The mixture was gently agitated for $2 \mathrm{~h}$. Then the coupling solution was drained and collected, and the excessive active ester of $\mathbf{2 1}$ could be hydrolyzed to $\mathbf{2 1}$ during DMF removal. Tripeptide $\mathbf{2 1}$ could be recovered from the residue by silica gel flash chromatography $(\mathrm{DCM}: \mathrm{MeOH}=30: 1)$. At last, the resin was washed with DMF $(10$ $\mathrm{mL} \times 3), \mathrm{CH}_{2} \mathrm{Cl}_{2}(10 \mathrm{~mL} \times 3)$ and $\mathrm{DMF}(10 \mathrm{~mL} \times 3)$.

\section{Resin linked peptide S9:}

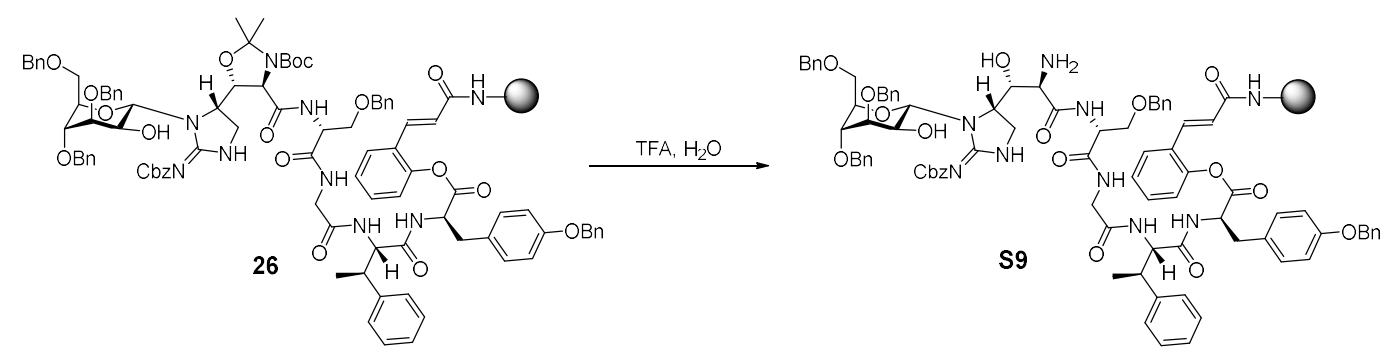

The Boc and acetonide group in $\mathbf{2 6}$ were removed by TFA with $0.1 \%$ water ( $15 \mathrm{~min})$ followed by sequential washing with $\mathrm{CH}_{2} \mathrm{Cl}_{2}(10 \mathrm{~mL} \times 3)$, iso-propanol $(10 \mathrm{~mL} \times 3)$, DMF (10 mL x 3) and $\mathrm{CH}_{2} \mathrm{Cl}_{2}(10 \mathrm{~mL} \times 3)$.

\section{Resin linked peptide 27:}




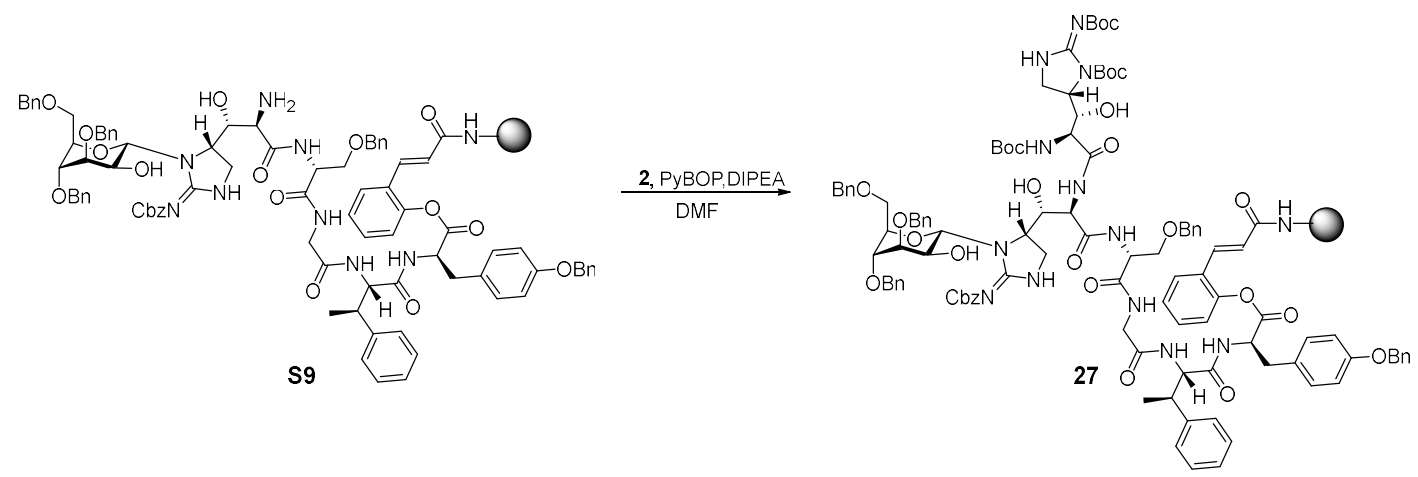

To mixture of Resin linked peptide S9 (0.084 mmol), PyBOP (175 mg, $0.336 \mathrm{mmol}$.) and DIPEA (75 $\mu \mathrm{L}, 0.420 \mathrm{mmol}$ ) $)$ in anhydrous DMF (5 mL) was added 2 (150 mg, $0.252 \mathrm{mmol}$ ) slowly during $3 \mathrm{~h}$ in several portions. Then the mixture was gently agitated for another $1 \mathrm{~h}$. At last, the solvent was drained and the resin was washed with DMF (10 mL x 3), $\mathrm{CH}_{2} \mathrm{Cl}_{2}(10 \mathrm{~mL} \times 3)$ and $\mathrm{DMF}(10 \mathrm{~mL} \times 3)$.

\section{Resin link peptide S10:}

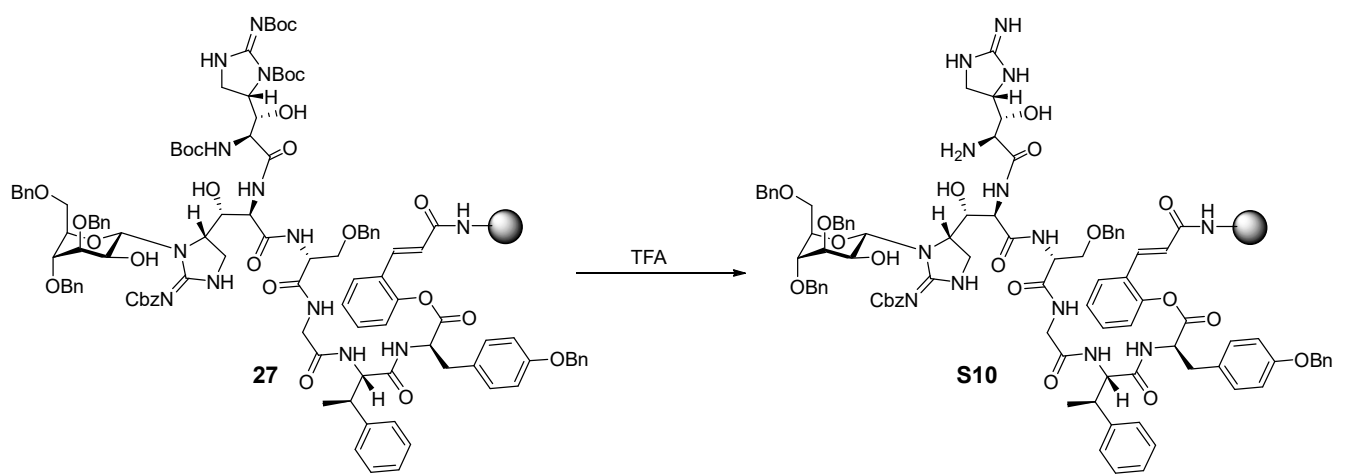

The Boc group in 27 were removed by TFA (20 min) followed by sequential washing with $\mathrm{CH}_{2} \mathrm{Cl}_{2}(10 \mathrm{~mL} \times 3)$, iso-propanol (10 mL x 3), DMF $(10 \mathrm{~mL} \times 3)$ and $\mathrm{CH}_{2} \mathrm{Cl}_{2}(10$ $\mathrm{mL} \times 3)$. 


\section{Compound S11:}

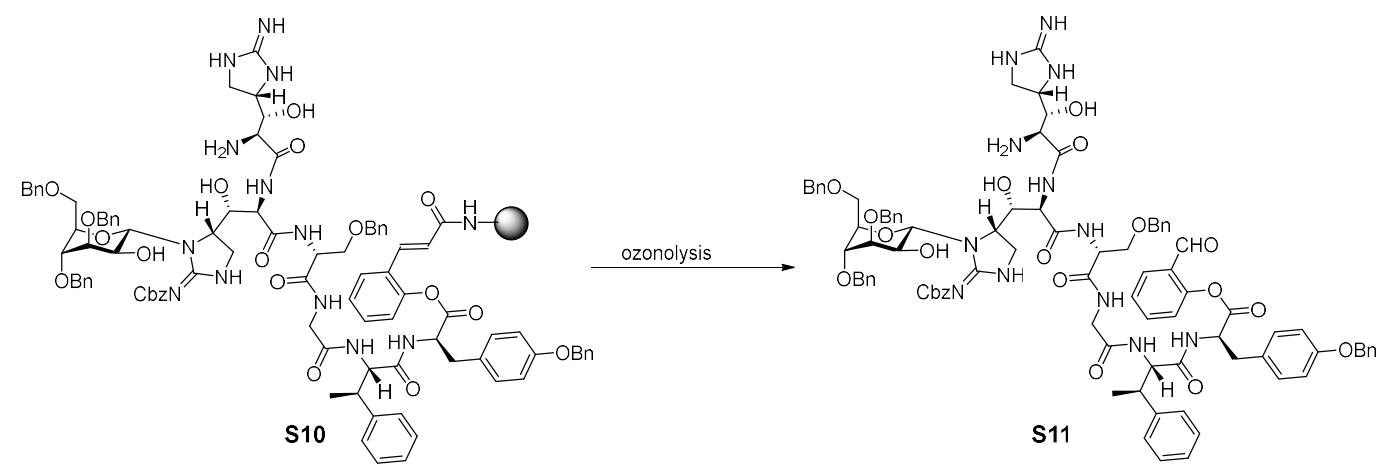

The resin linked peptide $\mathbf{S 1 0}$ was swollen in $\mathrm{CH}_{2} \mathrm{Cl}_{2} /$ TFA $(95: 5, v / v)$ at $-78^{\circ} \mathrm{C}$. After the mixture was treated with $\mathrm{O}_{3}$ at $-78^{\circ} \mathrm{C}$ for $5 \mathrm{~min}, \mathrm{Me}_{2} \mathrm{~S}$ (10.0 equiv. relative to resin capacity) was then added at $-78^{\circ} \mathrm{C}$. The reaction mixture was allowed to warm to room temperature over $1 \mathrm{~h}$. The mixture was then filtered and the filtrate was concentrated in vacuo to afford compound S11 which can be used for the next step without further purification. Few beads were treated with $\mathrm{TFA} / \mathrm{H}_{2} \mathrm{O}(95 / 5)$ for following UPLC analysis. 


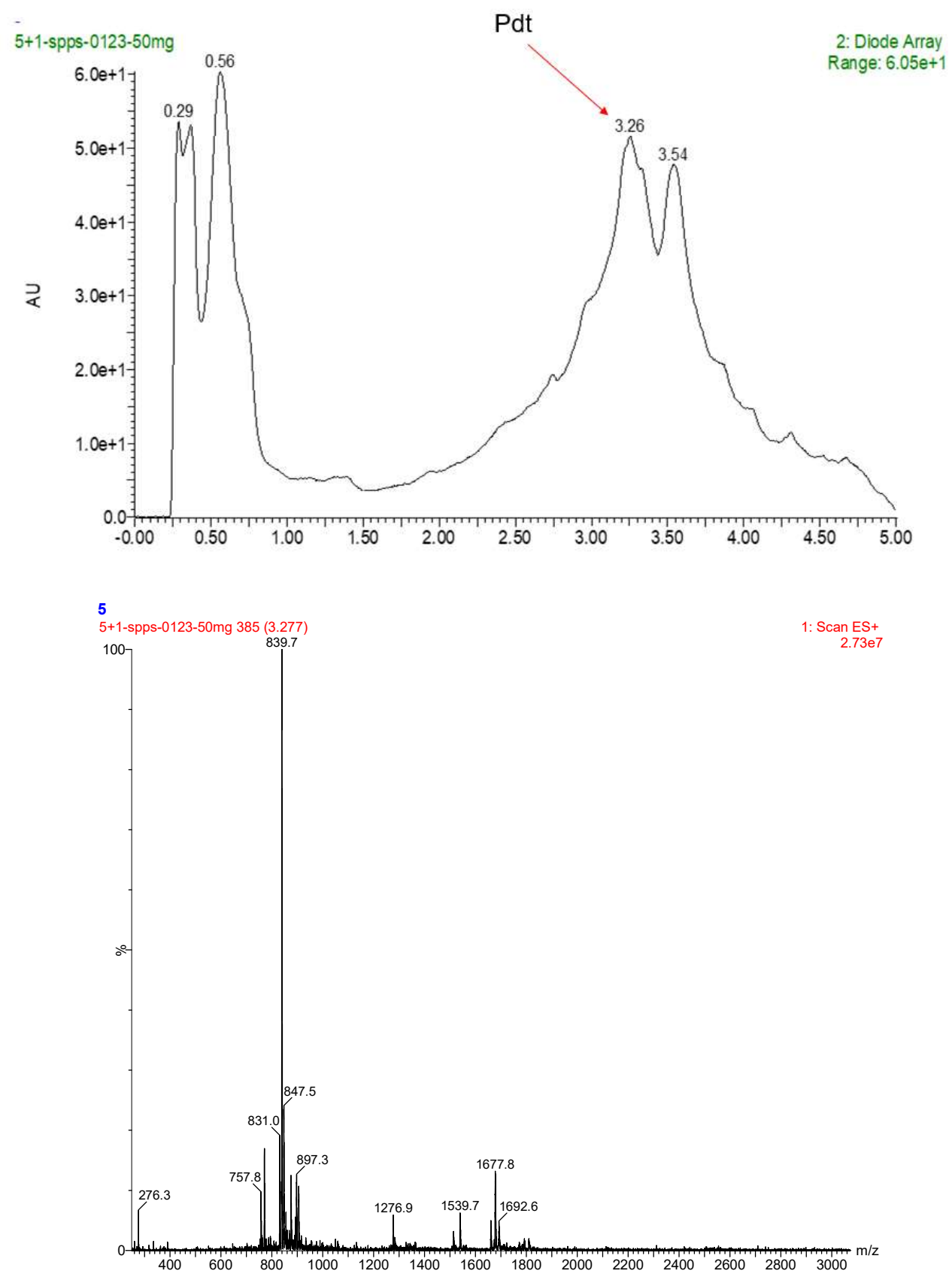

Figure S1. UV and ESI-MS trace from UPLC analysis of Hexapeptide-SAL ester S11: gradient 5-95\% $\mathrm{CH}_{3} \mathrm{CN} / \mathrm{H}_{2} \mathrm{O}$ containing $0.1 \%$ TFA over 5 min at a flow rate of 0.4 $\mathrm{mL} / \mathrm{min}$. ESI-MS calcd. for $\mathrm{C}_{92} \mathrm{H}_{100} \mathrm{~N}_{12} \mathrm{O}_{19}[\mathrm{M}+\mathrm{H}]^{+} \mathrm{m} / \mathrm{z}=1677.9$, found 1677.8.

\section{Compound S12:}



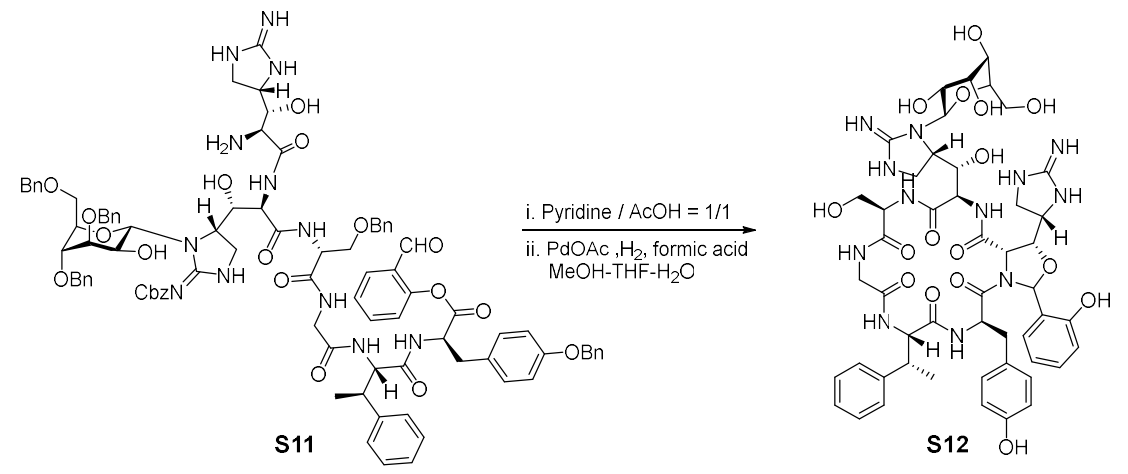

Hexapeptide-SAL ester S11 (0.084 mmol in theory) was dissolved in pyridine/acetic acid $(1: 1 \mathrm{~mole} / \mathrm{mole})$ at a concentration of $2 \mathrm{mM}$ at room temperature. The reaction mixture was stirred at room temperature for $24 \mathrm{~h}$. The solvent was removed in vacuo and the resulting residue could be used for the next step without further purification.

To a solution of compound $\mathbf{2 8}$ (From last step, $0.084 \mathrm{mmol}$ in theory) in mixed solvents of THF-MeOH- $\mathrm{H}_{2} \mathrm{O}-\mathrm{HCOOH}(10 \mathrm{~mL})$ with the ratio as $1: 1: 1: 0.05$ was added $\mathrm{Pd}(\mathrm{OAc})_{2}$ (112 $\mathrm{mg}, 0.504 \mathrm{mmol})$ and the reaction mixture was stirred at room temperature under $\mathrm{H}_{2}(50 \mathrm{~atm})$ for $48 \mathrm{~h}$. Then the reaction mixture was filtered and concentrated in vacuo. The residue was purified by reversed phase HPLC $\left(10 \%-50 \% \mathrm{CH}_{3} \mathrm{CN}\right.$ in water containing $0.1 \%$ TFA) to give compound $\mathbf{S 1 2}$ as a white solid.

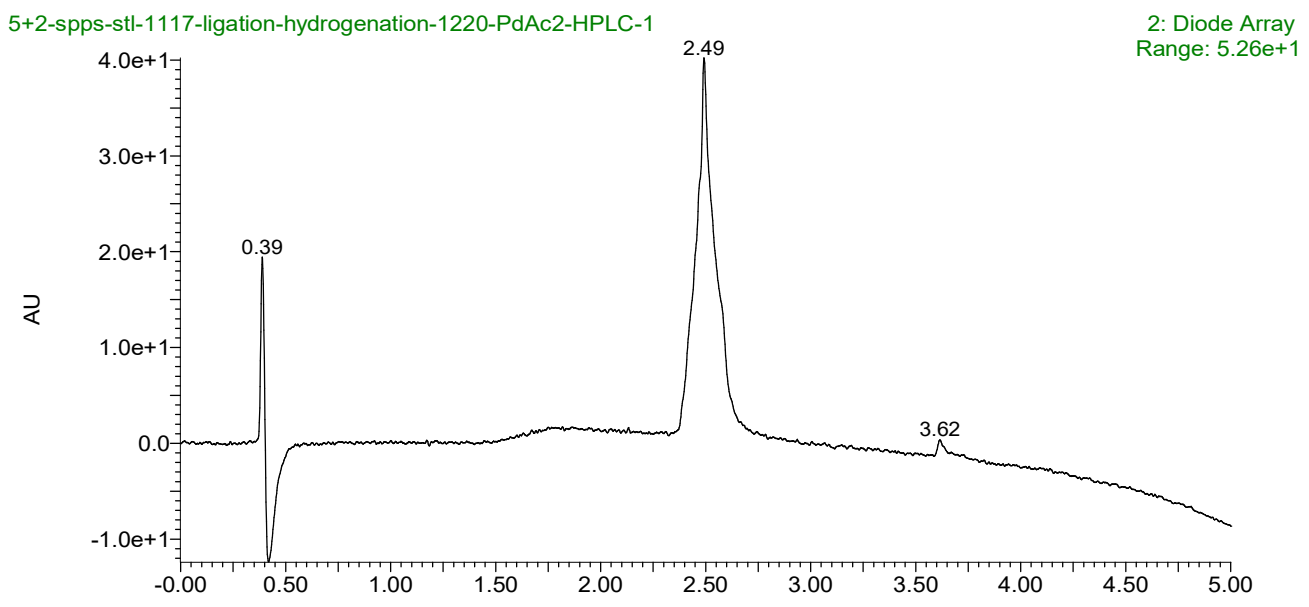




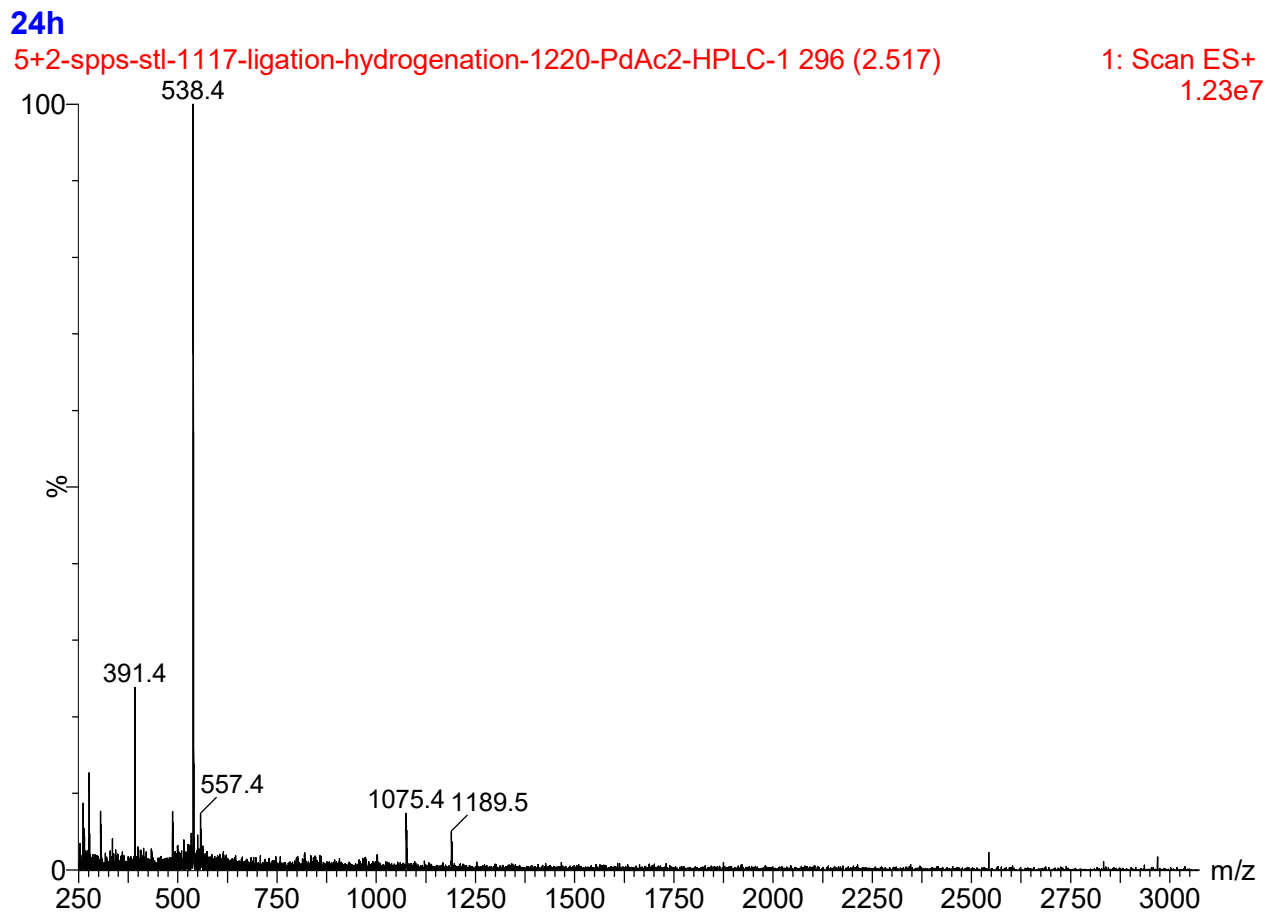

Figure S2. UV and ESI-MS spectra from UPLC analysis of purified peptide S12: gradient 5-95\% $\mathrm{CH}_{3} \mathrm{CN} / \mathrm{H}_{2} \mathrm{O}$ containing $0.1 \%$ TFA over $5 \mathrm{~min}$ at a flow rate of 0.4 $\mathrm{mL} / \mathrm{min}$. ESI-MS calcd. For $\mathrm{C}_{49} \mathrm{H}_{62} \mathrm{~N}_{12} \mathrm{O}_{16}[\mathrm{M}+\mathrm{H}]^{+} \mathrm{m} / \mathrm{z}=1075.1$, found 1075.4; $[\mathrm{M}+2 \mathrm{H}]^{2+} \mathrm{m} / \mathrm{z}=538.6$, found 538.5 .

\section{Compound 1 (mannopeptimycin $\beta)$ :}

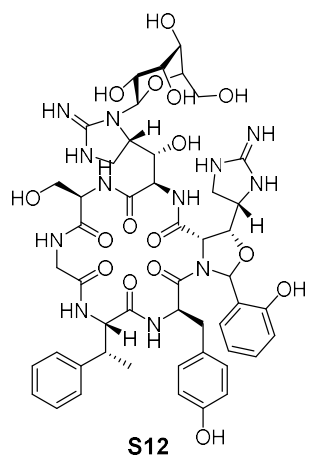

$1 \mathrm{M} \mathrm{HCl} / \mathrm{HFIP}$

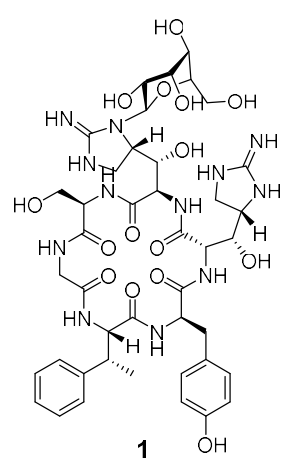

The compound $\mathbf{S 1 2}(0.084 \mathrm{mmol}$ in theory) was treated with $1 \mathrm{M} \mathrm{HCl}$ in Hexafluoro-2- 
propanol (HFIP) solution ( $5 \mathrm{~mL}$ ) (concentrated $\mathrm{HCl}$ aq. diluted with HFIP) and stirred at room temperature for $4 \mathrm{~h}$. After fully conversion, the solvent was removed by a stream of condensed air and purified by reversed phase HPLC $\left(10 \%-50 \% \mathrm{CH}_{3} \mathrm{CN}\right.$ in water containing $0.1 \%$ TFA) to give $9 \mathrm{mg}$ mannopeptimycin $\boldsymbol{\beta}$ (TFA salt) in $11 \%$ yield during 12 steps as a white solid. ${ }^{1} \mathrm{H}$ NMR (400 MHz, $\mathrm{D}_{2} \mathrm{O}-\mathrm{MeOH}-\mathrm{d} 4=1: 1$ in volume) $\delta 7.55-7.16(\mathrm{~m}, 5 \mathrm{H}), 6.96(\mathrm{~d}, J=8.2 \mathrm{~Hz}, 2 \mathrm{H}), 6.75(\mathrm{~d}, J=8.1 \mathrm{~Hz}, 2 \mathrm{H}), 5.06$ $(\mathrm{d}, J=8.3 \mathrm{~Hz}, 1 \mathrm{H}), 4.60(\mathrm{~d}, J=5.0 \mathrm{~Hz}, 1 \mathrm{H}), 4.48(\mathrm{t}, J=5.2 \mathrm{~Hz}, 1 \mathrm{H}), 4.36(\mathrm{~d}, J=10.3$ $\mathrm{Hz}, 1 \mathrm{H}), 4.30-4.10(\mathrm{~m}, 6 \mathrm{H}), 4.08-3.97(\mathrm{~m}, 3 \mathrm{H}), 3.94-3.77(\mathrm{~m}, 5 \mathrm{H}), 3.77-3.62(\mathrm{~m}$, 2H), $3.51(\mathrm{t}, J=8.4 \mathrm{~Hz}, 1 \mathrm{H}), 3.21-3.04(\mathrm{~m}, 2 \mathrm{H}), 2.47(\mathrm{t}, J=9.1 \mathrm{~Hz}, 1 \mathrm{H}), 2.40(\mathrm{t}, J=$ $12.3 \mathrm{~Hz}, 1 \mathrm{H}), 1.95(\mathrm{~d}, J=9.3 \mathrm{~Hz}, 1 \mathrm{H}), 1.35(\mathrm{~d}, J=6.8 \mathrm{~Hz}, 3 \mathrm{H}) ;{ }^{13} \mathrm{C} \mathrm{NMR}(151 \mathrm{MHz}$, $\mathrm{D}_{2} \mathrm{O}-\mathrm{MeOH}-d 4=1: 1$ in volume) $\delta 174.34,173.85,173.48,173.33,173.15,172.90$, 165.16(TFA), 164.92(TFA), 161.87, 161.59, 158.07, 144.60, 133.02, 131.20, 130.41, $130.27,129.89,129.81,122.16,120.22,118.28,117.67,116.34,83.36,82.62,73.57$, $72.19,71.61,71.20,67.51,63.92,63.72,62.78,61.62,58.32,58.13,57.62,56.72,55.97$, 44.93, 44.59, 44.43, 44.07, 38.53, 19.70. HR-ESI-MS (m/z): calcd for $\mathrm{C}_{42} \mathrm{H}_{58} \mathrm{~N}_{12} \mathrm{O}_{15} \mathrm{H}_{2}{ }^{2+}[\mathrm{M}+2 \mathrm{H}]^{2+}: 250.2072$, found: 486.2135 . 


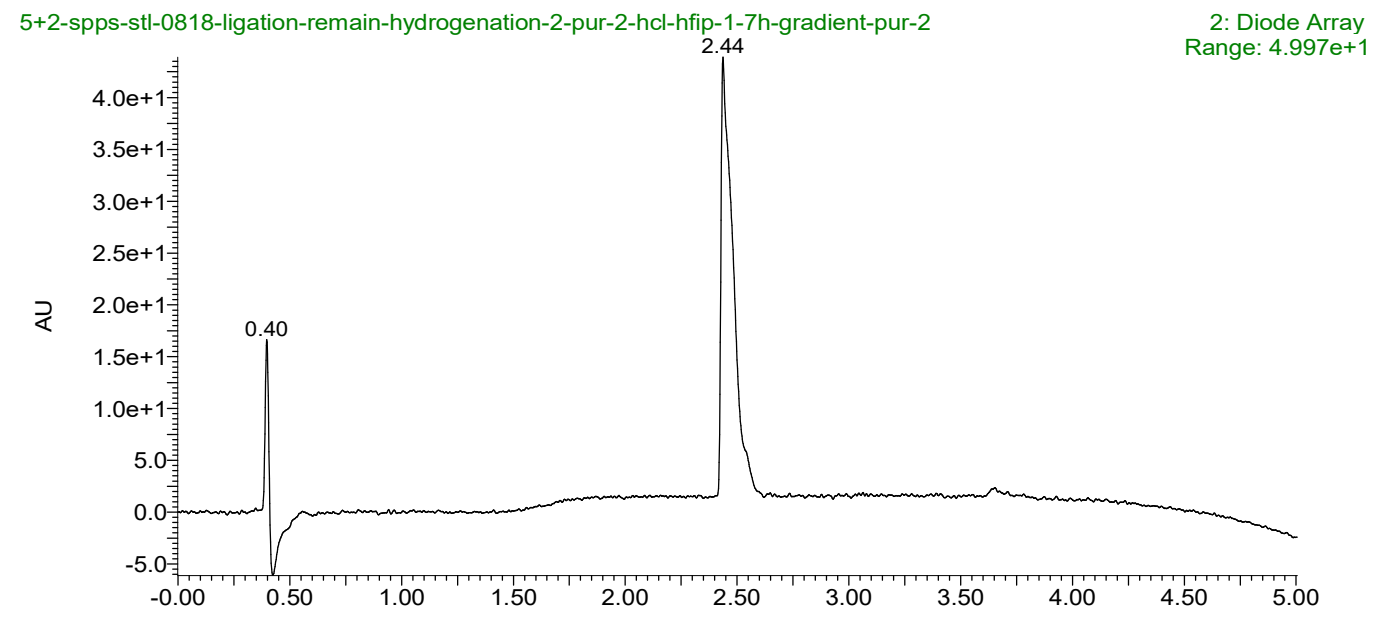

\section{$3.5 \mathrm{~h}$}

5+2-spps-stl-0818-ligation-remain-hydrogenation-2-pur-2-hcl-hfip-1-7h-gradient-pur-2 291 (2.477)

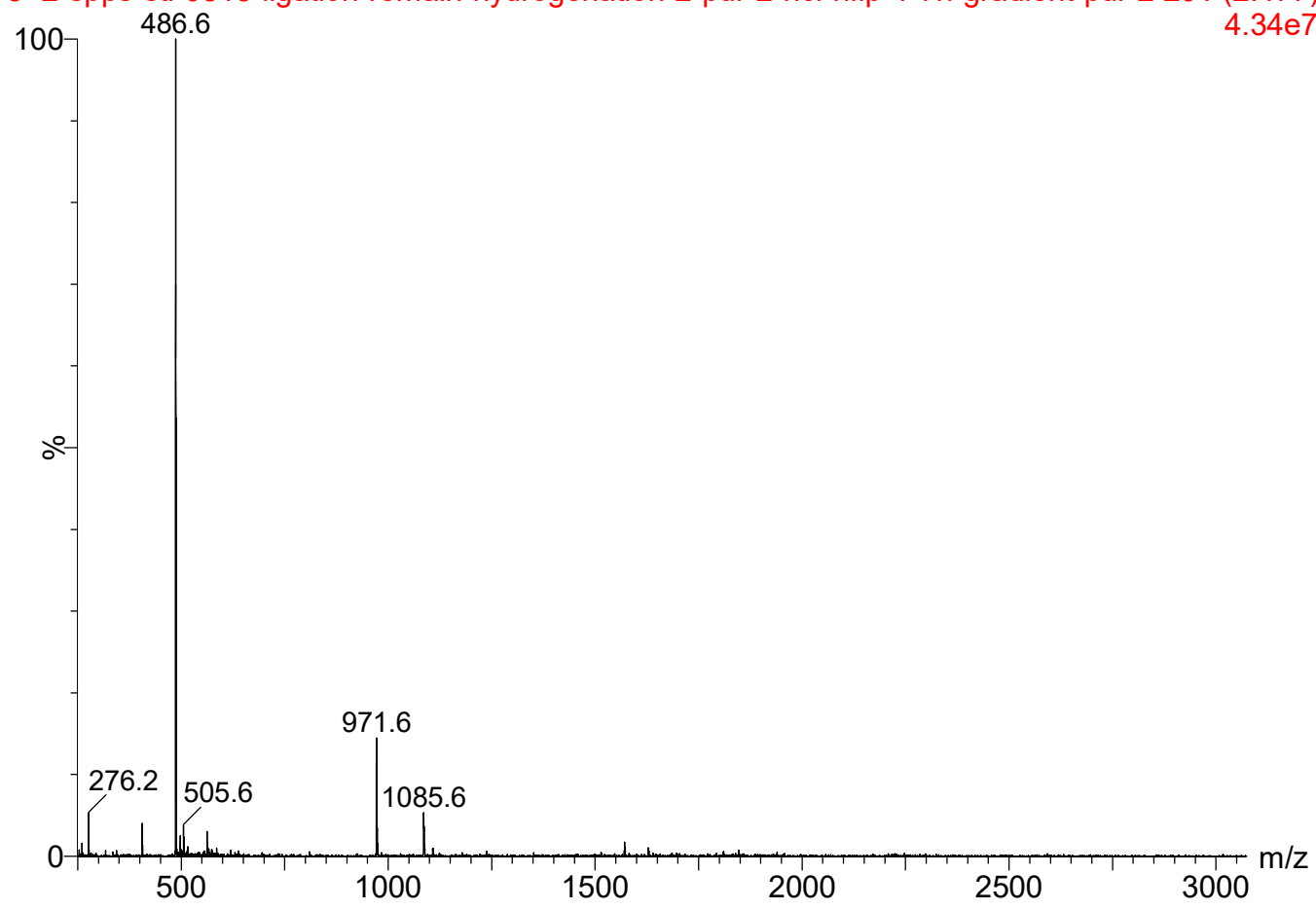

Figure S3. UV and ESI-MS spectra from UPLC analysis of purified mannopeptimycin $\beta$ : gradient $5-95 \% \mathrm{CH}_{3} \mathrm{CN} / \mathrm{H}_{2} \mathrm{O}$ containing $0.1 \%$ TFA over 5 min at a flow rate of 0.4 $\mathrm{mL} / \mathrm{min}$. ESI-MS calcd. For $\mathrm{C}_{42} \mathrm{H}_{58} \mathrm{~N}_{12} \mathrm{O}_{15}[\mathrm{M}+\mathrm{H}]^{+} \mathrm{m} / \mathrm{z}=971.4$, found 971.6; $[\mathrm{M}+2 \mathrm{H}]^{2+} \mathrm{m} / \mathrm{z}=486.2$, found 486.6 . 
Table S1. ${ }^{13} \mathrm{C}-\mathrm{NMR}$ ( $\mathrm{D}_{2} \mathrm{O}-\mathrm{MeOH}-d 4=1: 1$ in volume, $151 \mathrm{MHz}$ ) Spectroscopic

Data Comparison for Natural Versus Synthetic Mannopeptimycin $\beta$

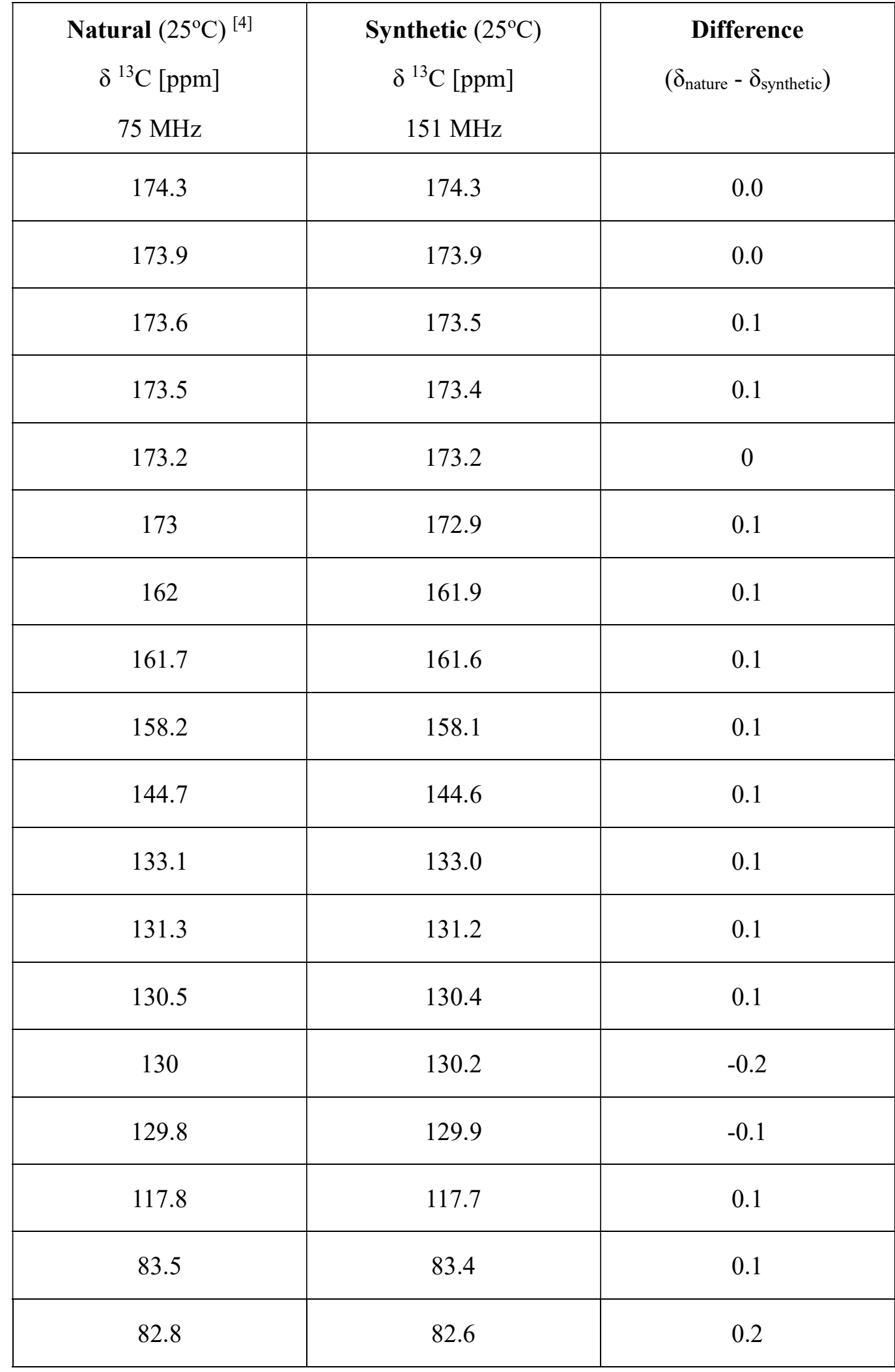




\begin{tabular}{|c|c|c|}
\hline 73.7 & 73.6 & 0.1 \\
\hline 72.2 & 72.2 & 0.0 \\
\hline 71.9 & 71.6 & 0.3 \\
\hline 71.3 & 71.2 & 0.1 \\
\hline 67.6 & 67.5 & 0.1 \\
\hline 63.8 & 63.9 & -0.1 \\
\hline 63.8 & 63.7 & 0.1 \\
\hline 62.8 & 62.8 & 0.0 \\
\hline 61.8 & 61.6 & 0.2 \\
\hline 58.3 & 58.3 & 0.0 \\
\hline 58.3 & 58.2 & 0.1 \\
\hline 57.8 & 57.6 & 0.2 \\
\hline 56.8 & 56.7 & 0.1 \\
\hline 56.1 & 56.0 & 0.1 \\
\hline 45.1 & 44.9 & 0.2 \\
\hline 44.8 & 44.6 & 0.2 \\
\hline 44.5 & 44.4 & 0.1 \\
\hline 44.2 & 44.1 & 0.1 \\
\hline 38.7 & 38.5 & 0.2 \\
\hline 19.7 & 19.7 & 0 \\
\hline
\end{tabular}


Table S1. ${ }^{1} \mathrm{H}-\mathrm{NMR}\left(\mathrm{D}_{2} \mathrm{O}-\mathrm{MeOH}-d 4=1: 1\right.$ in volume, $\left.400 \mathrm{MHz}\right)$ Spectroscopic Data

Comparison for Natural Versus Synthetic Mannopeptimycin $\beta$

\begin{tabular}{|c|c|c|}
\hline Natural $\left(25^{\circ} \mathrm{C}\right)^{[4]}$ & Synthetic $\left(25^{\circ} \mathrm{C}\right)$ & Difference \\
\hline$\delta{ }^{1} \mathrm{H}[\mathrm{ppm}]$ & $\delta{ }^{1} \mathrm{H}[\mathrm{ppm}]$ & $\left(\delta_{\text {nature }}-\delta_{\text {synthetic }}\right)$ \\
\hline $300 \mathrm{MHz}$ & $400 \mathrm{MHz}$ & \\
\hline 1.34 & 1.35 & -0.01 \\
\hline 1.97 & 1.95 & 0.02 \\
\hline 2.42 & 2.40 & 0.02 \\
\hline 2.51 & 2.47 & 0.04 \\
\hline 3.12 & $3.21-3.04$ & U.C. \\
\hline 3.15 & $3.21-3.04$ & U.C. \\
\hline 3.37 & Overlapped with solvent peak & U.C. \\
\hline 3.51 & 3.51 & 0.00 \\
\hline 3.65 & $3.77-3.62$ & U.C. \\
\hline 3.68 & $3.77-3.62$ & U.C. \\
\hline 3.79 & $3.77-3.62$ & U.C. \\
\hline 3.84 & $3.94-3.77$ & U.C. \\
\hline 3.85 & $3.94-3.77$ & U.C. \\
\hline 3.86 & $3.94-3.77$ & U.C. \\
\hline 3.99 & $4.08-3.97$ & U.C. \\
\hline 4.02 & $4.08-3.97$ & U.C. \\
\hline 4.05 & $4.08-3.97$ & U.C. \\
\hline
\end{tabular}




\begin{tabular}{|c|c|c|}
\hline 4.15 & $4.30-4.10$ & U.C. \\
\hline 4.20 & $4.30-4.10$ & U.C. \\
\hline 4.20 & $4.30-4.10$ & U.C. \\
\hline 4.23 & $4.30-4.10$ & U.C. \\
\hline 4.23 & $4.30-4.10$ & U.C. \\
\hline 4.24 & $4.30-4.10$ & U.C. \\
\hline 4.38 & 4.36 & 0.02 \\
\hline 4.49 & 4.48 & 0.01 \\
\hline 4.59 & 4.60 & -0.01 \\
\hline 5.06 & 5.06 & -0.02 \\
\hline 6.73 & 6.75 & U.C. \\
\hline 7.30 & $6.96-7.16$ & -0.02 \\
\hline
\end{tabular}




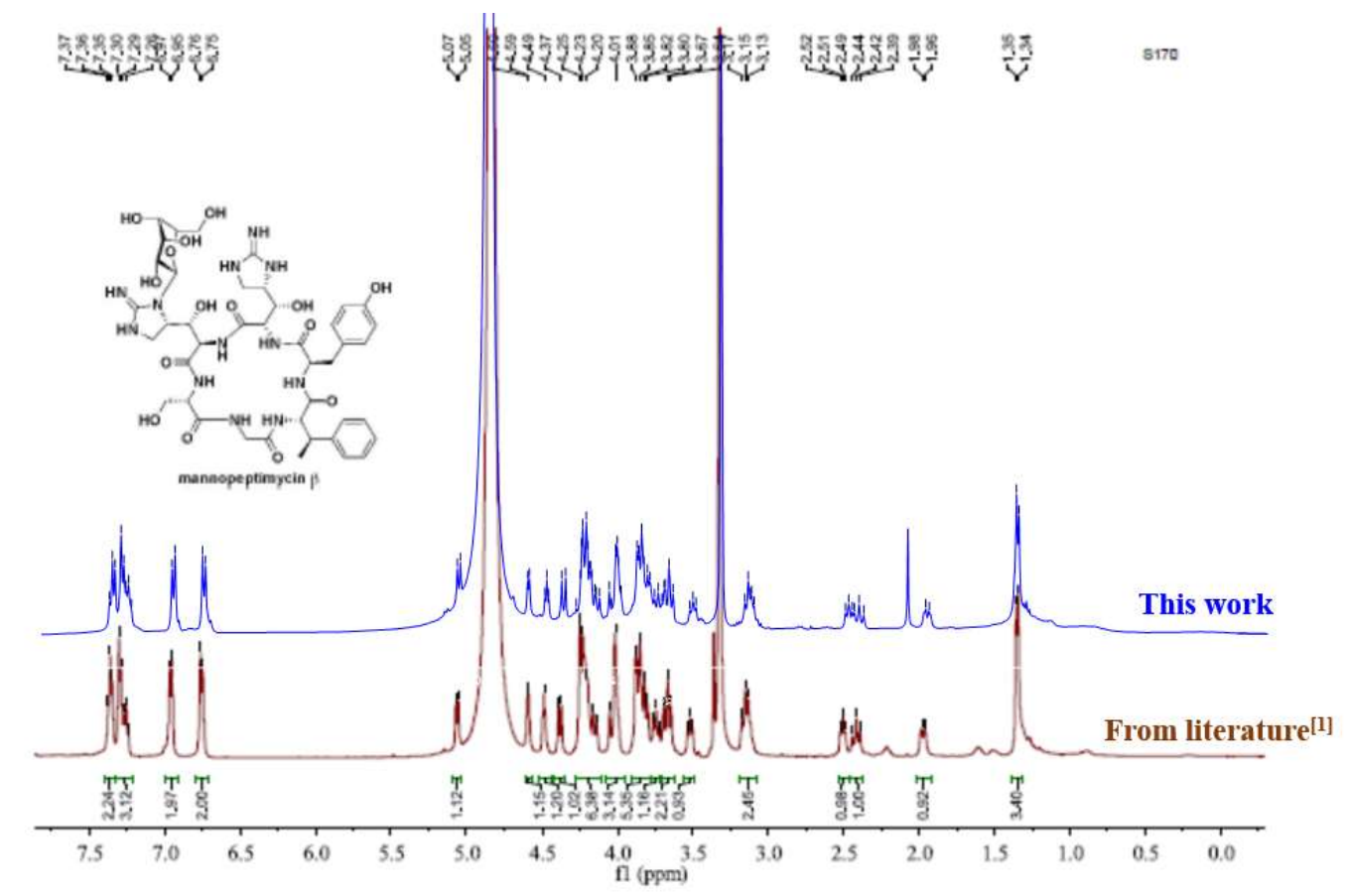

Figure S4. Comparison of ${ }^{1} \mathrm{H}-\mathrm{NMR}$ spectrum between literature reported mannopeptimycin $\beta^{[1]}$ and our synthetic one. ${ }^{*}$ The ${ }^{1} \mathrm{H}$ NMR spectrum of literature one was extracted from the literature ${ }^{[1]}$ and compared at the same scale with same reference. 


\section{Lipid II binding test of the synthetic mannopeptimycin $\beta$}

Lipid II overproduction and purification from $S$. aureus was performed using method from Qiao et al ${ }^{[5]}$. Binding of the synthetic mannopeptimycin $\beta$ to lipid II was evaluated by incubating $20 \mathrm{nmol}$ of lipid II with 20 and $40 \mathrm{nmol}$ of Mannopeptimycin $\beta$ in $100 \mathrm{mM}$ Tris- $\mathrm{HCl}, \mathrm{pH} 7.5,13 \mathrm{mM} \mathrm{MgCl}_{2}$ and $0.1 \%$ Triton $\mathrm{X}-100$, for $60 \mathrm{~min}$ at $37{ }^{\circ} \mathrm{C}$ (Lipid II: peptide ratios 1:1 and 1:2, respectively). End10Chg-teixobactin was used as positive control (40 nmol, Lipid II: peptide ratio $1: 2)^{[6,7]}$. Subsequently, the mixture was extracted four times with $n-\mathrm{BuOH} / 6 \mathrm{M}$ pyridinium acetate buffer, $\mathrm{pH} 4.2$ $(3: 1, v / v)$. The butanol fraction was evaporated and the residue was dissolved in $\mathrm{CHCl}_{3} /$ methanol $(1: 1, \mathrm{v} / \mathrm{v})$. The resuspension was analysed for the loss of free Lipid II by TLC analysis using chloroform/methanol/water/ammonia $(88: 48: 10: 1, \mathrm{v} / \mathrm{v} / \mathrm{v} / \mathrm{v})$ as the solvent and detection by Phosphomolybdic Acid (PMA) Staining.

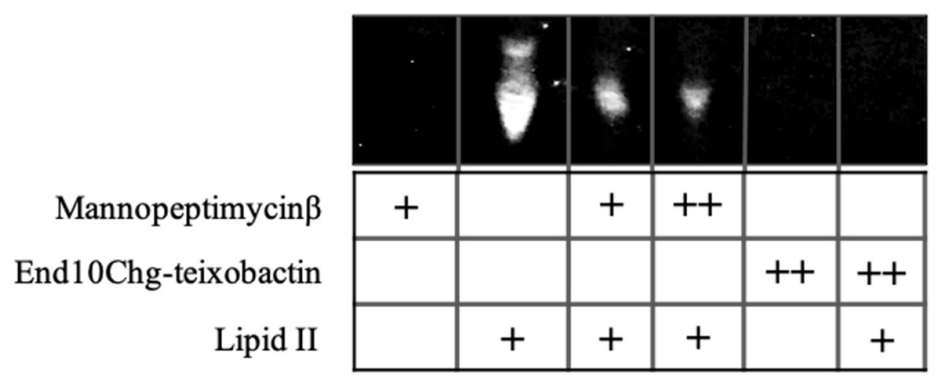

Figure S5. Complex formation of Mannopeptimycin $\beta$ with purified Lipid II. End10Chg-teixobactin was used as positive control. Binding of Mannopeptimycin $\beta$ is shown by a reduction of the amount of lipid II (visible on the thin-layer chromatogram (TLC)). + corresponds to 1 eq, ++2 eq. 


\section{Unsuccessful attempts towards mannopeptimycin and the}

\section{evolution of the strategy}

\section{i. Other attempts toward the synthesis of $N$ - $\alpha$-mannosylated $D-\beta h E n d$}

Several approaches to facilitate the efficient synthesis of $N$ - $\alpha$-mannosylated D$\beta$ hEnd have been attempted. Some representative unsuccessful trials are shown in Figure S6.
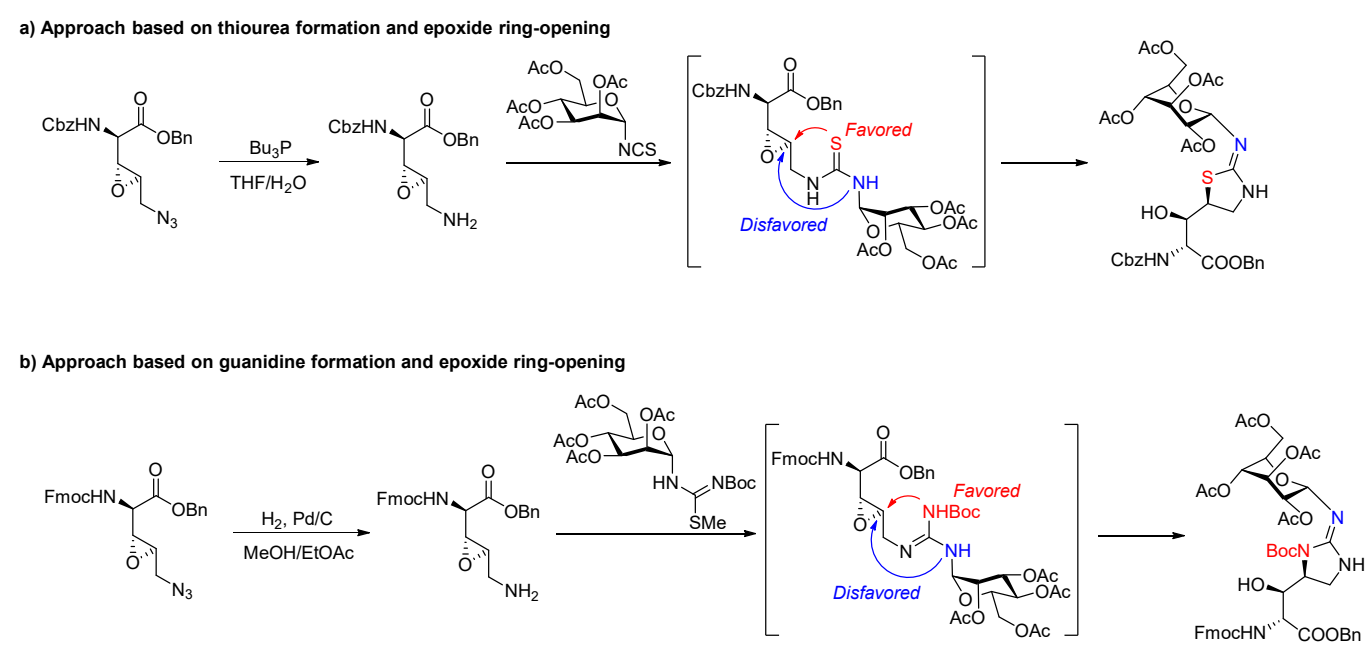

Other $\mathrm{N}$-mannoside based $\mathrm{S}$-Me isothiourea species tested in this approach
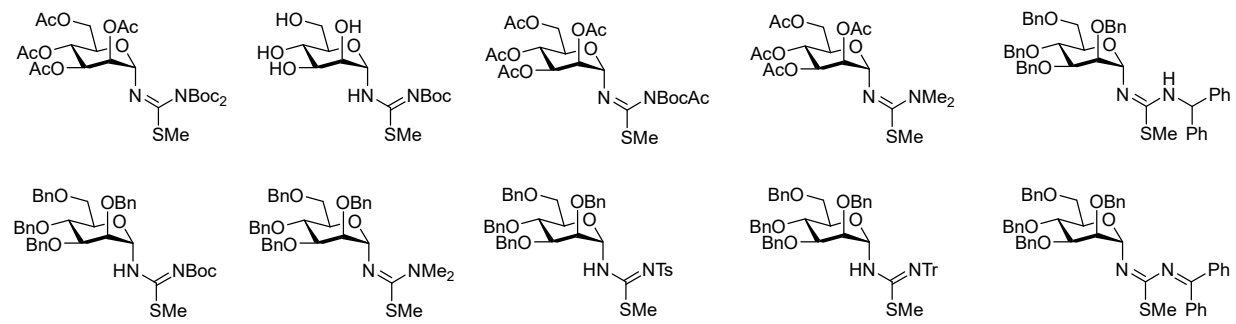

Figure S6. Unsuccessful attempts towards $N$ - $\alpha$-mannosylated D- $\beta$ hEnd synthesis.

With our success in the synthesis of L- $\beta$ hEnd building block using in situ intramolecular epoxide ring-opening by guanidine, we attempted to synthesize the more challenging $N$ - $\alpha$-mannosylated $\mathrm{D}$ - $\beta$ hEnd building block based on the same logic. To explore a new non-glycosylation way to install the $N$ - $\alpha$-mannoside, we tried to prepare 
the mannosylated thiourea from epoxide-amine species and $\alpha$-mannosyl isothiocyanate. Though the thiourea formation took place smoothly, the more nucleophilic sulfur atom directly attacked the epoxide in 5-exo-tet manner to give the undesired product. As an alternative approach, the $N$ - $\alpha$-mannosyl guanidine species was prepared from the corresponding $S$-methyl isothiourea reagent. Unfortunately, though bearing electronwithdrawing Boc group, the incorrect nitrogen still attacked the epoxide and gave rise

to the undesired product. Further tuning the nucleophilicity of the sugar-bearing nitrogen via changing the protecting groups was unsuccessful.

\section{ii. Attempts toward the total synthesis of mannopeptimycin via solution phase peptide synthesis}

At the early stage of our adventure towards the synthesis of mannopeptimycin, before successfully achieving the combined solution phase/solid phase approach, we attempted several strategies based on solution phase peptide synthesis. The unsuccessful attempts were summarized in the following figures. 

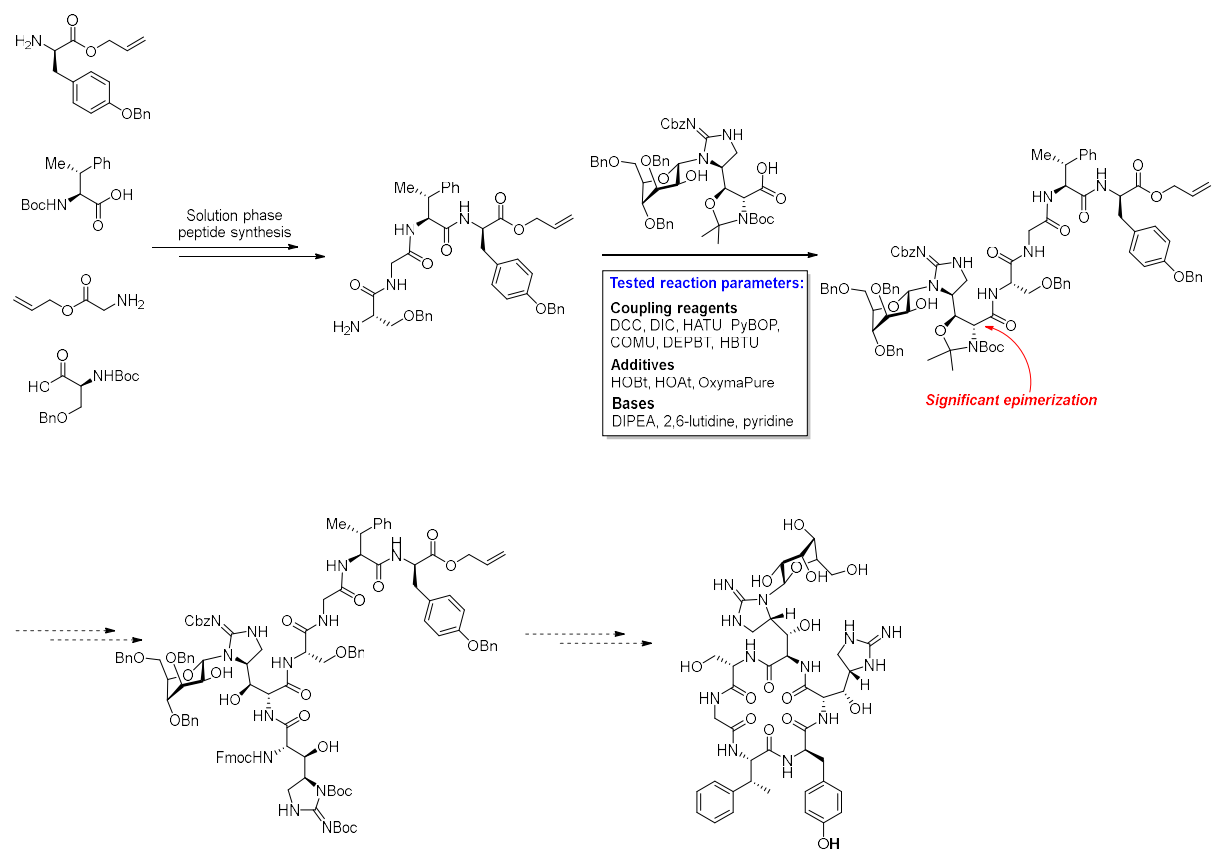

Spectra of the isolated epimers in $4+1$ process

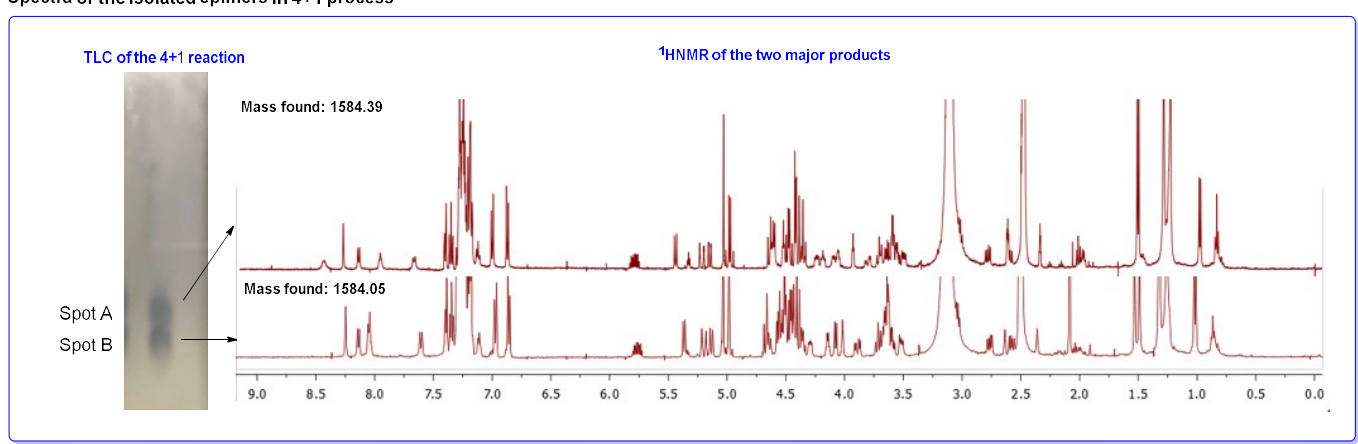

Figure S7. The $1^{\text {st }}$ generation approach based on the solution phase $[4+1+1]$ strategy.

As the $1^{\text {st }}$ generation approach, we attempted the solution phase $4+1+1$ peptide assembly (Figure S7). Though the tetrapeptide was readily prepared from corresponding building blocks in good efficiency, during the installation of the $5^{\text {th }}$ amino acid, $N$ - $\alpha$-mannosylated $\mathrm{D}-\beta \mathrm{h} E n d$, we encountered serious epimerization problem. We optimized the coupling reaction parameters including coupling reagents, additives and bases, however, two epimers were obtained in all tested cases. The two epimers were isolated by preparative TLC and characterized by MS and NMR. We attributed this phenomenon to the low coupling reactivity of both the tetrapeptide and 
the $N$ - $\alpha$-mannosylated D- $\beta$ hEnd. The $\alpha$ carbon of the activated $N$ - $\alpha$-mannosylated D$\beta$ hEnd building block underwent epimerization before coupling with the tetrapeptide N-terminus. Due to this serious epimerization and difficult separation which hampered the accumulation of the pentapeptide material, further elongation and cyclization attempt was discontinued, and we moved to the $2^{\text {nd }}$ generation approach.
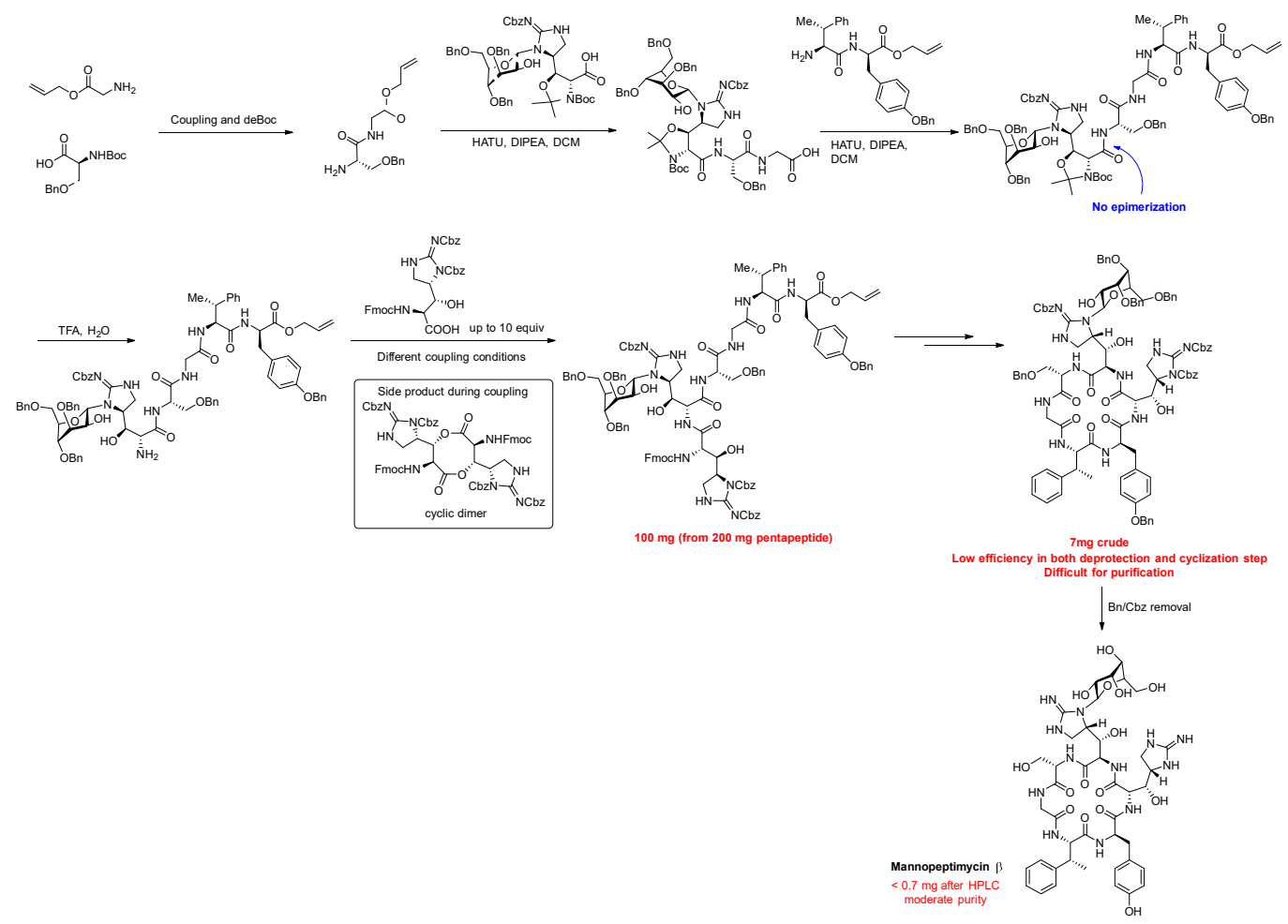

Figure S8. The $2^{\text {nd }}$ generation approach based on solution phase $[3+2+1]$ strategy.

In our $2^{\text {nd }}$ generation approach, to solve the epimerization problem, we tried to improve the coupling reactivity of the partner. Thus, the tetrapeptide used in the former approach was replaced by a dipeptide. To out delight, using the same $N$ - $\alpha$-mannosylated D- $\beta$ hEnd building block, the epimerization was totally suppressed, and the desired tripeptide was obtained. Further coupling with another dipeptide at the C-terminal Gly was finished without difficulty. During the installation of the $6^{\text {th }}$ amino acid residue, though the desired amide bond was formed without epimerization, the conversion was 
incredibly low, and up to 10 equiv of the $\mathrm{L}-\beta \mathrm{hEnd}$ building block was consumed to achieve manageable conversion of the pentapeptide. Due to the unprotected hydroxyl group in the L- $\beta$ hEnd building block, the excess L- $\beta$ hEnd building block underwent intermolecular dimerization as confirmed by LC-MS analysis and became inactive, which led to unsuccessful attempt to reduce the L- $\beta$ hEnd building block consumption by elongating reaction time. Though the conversion was far from satisfying, we still accumulated $100 \mathrm{mg}$ hexapeptide through several rounds of coupling and recovery of pentapeptide. Unfortunately, in the following deprotection and cyclization steps, very low efficiency was encountered again. Only $7 \mathrm{mg}$ crude cyclic peptide was obtained eventually. After hydrogenolysis of Bn and Cyz groups, only $0.7 \mathrm{mg}$ mannopeptimycin $\beta$ was isolated by HPLC with moderate purity. The serious loss of material (from 100 $\mathrm{mg}$ to $0.7 \mathrm{mg}$ ) in only 4 steps was unacceptable, and further struggle with this approach was abandoned.

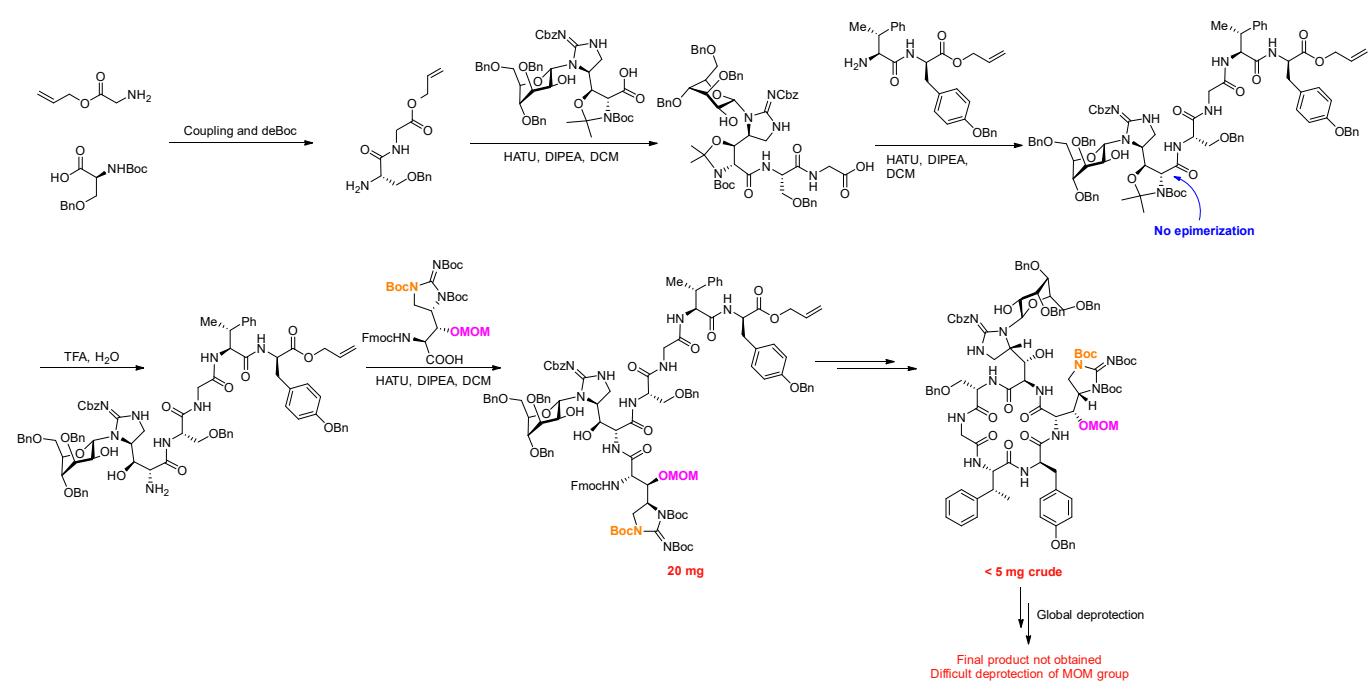

Figure S9. The $3^{\text {rd }}$ generation approach based on solution phase $[3+2+1]$ strategy. 
As mentioned in the $2^{\text {nd }}$ generation approach, the coupling of the $6^{\text {th }}$ amino acid L- $\beta$ hEnd building block was problematic, partially due to the existence of the unprotected $\beta$-hydroxyl group. To solve this problem, we tried to protect the $\beta$-hydroxyl group with MOM. To our delight, using this new building block, the efficiency of the coupling step was improved, and the consumption of the L- $\beta$ hEnd building block was reduced. After the following deprotection and cyclization steps, $<5 \mathrm{mg}$ crude cyclic peptide was obtained from $20 \mathrm{mg}$ hexapeptide, which was much better than the $2^{\text {nd }}$ generation approach. Unfortunately, in the final global deprotection step, we failed to get good conversion for the MOM removal, and the conversion was always less than $50 \%$. Protection of the $\beta$-hydroxyl group by other groups (e.g. TBS, TES, acetonide, allyl) were tested, however, in vein.

In summary, from the $1^{\text {st }}$ generation approach to the $3^{\text {rd }}$ generation one, we solved the epimerization problem in the coupling of $N$ - $\alpha$-mannosylated D- $\beta$ hEnd building block by changing the assembly pattern from $[4+1+1]$ to $[3+2+1]$ and got tiny amount of desired final product with the cost of consuming significant amount of linear hexapeptide. The low efficiency of the solution phase approaches in our hands was not only due to the low efficiency of the cyclization step, but also the tedious column chromatography purifications after every coupling and deprotection steps. To this end, we conceived of the idea of the combined solution phase/solid phase synthesis of the peptide and $\beta$-enduracididine ligation mediated cyclization. 


\section{iii. NMR Spectra}
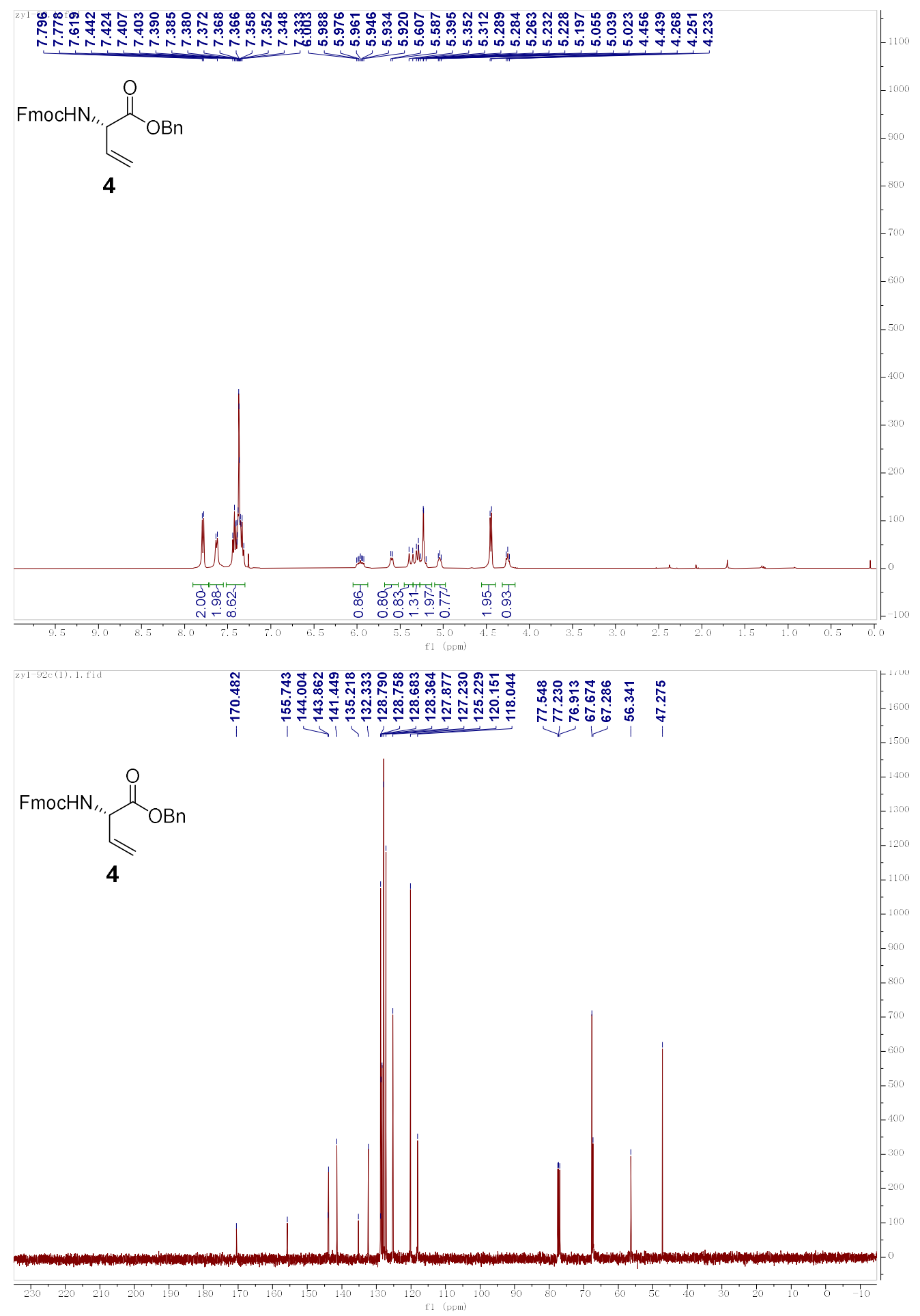

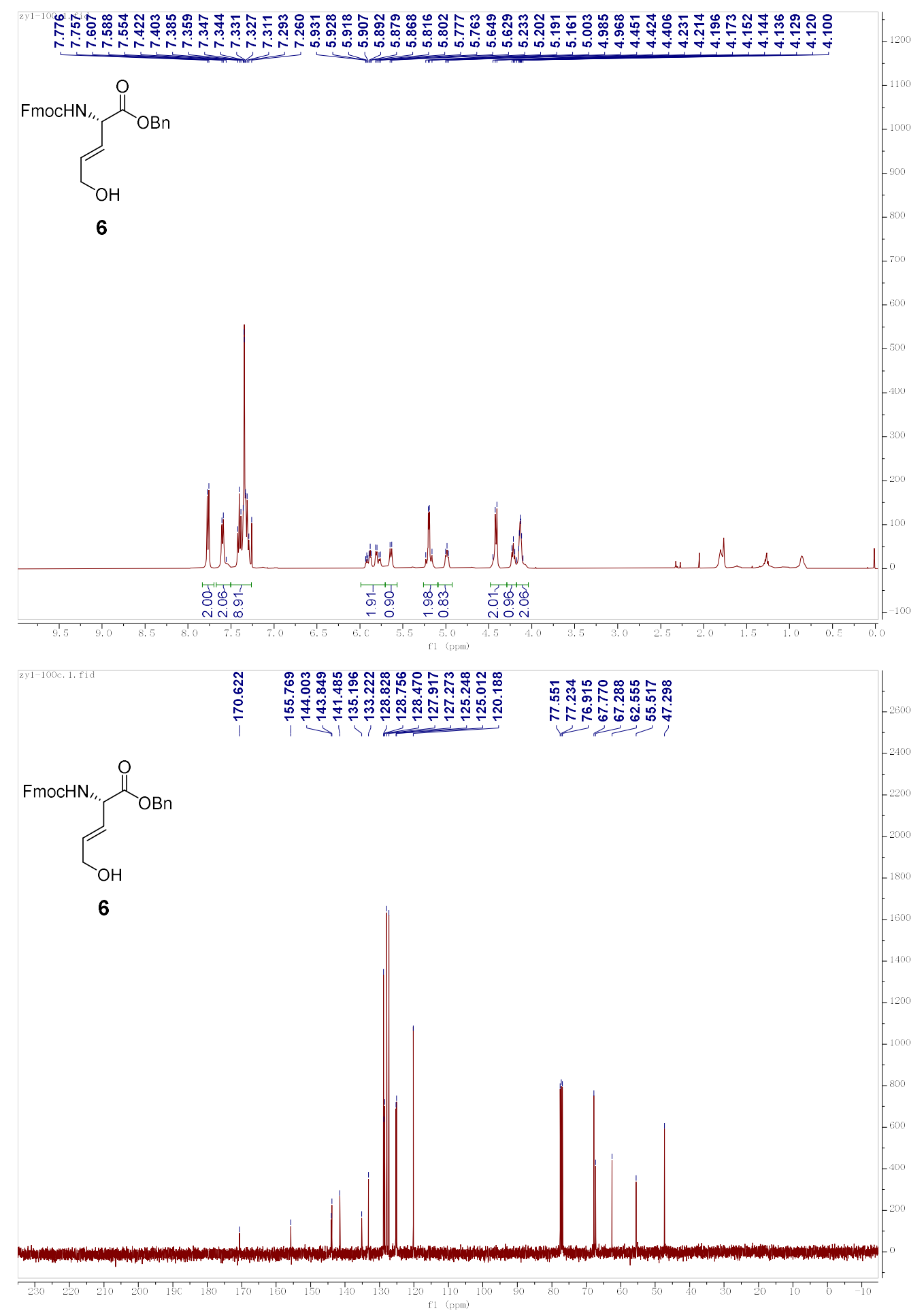

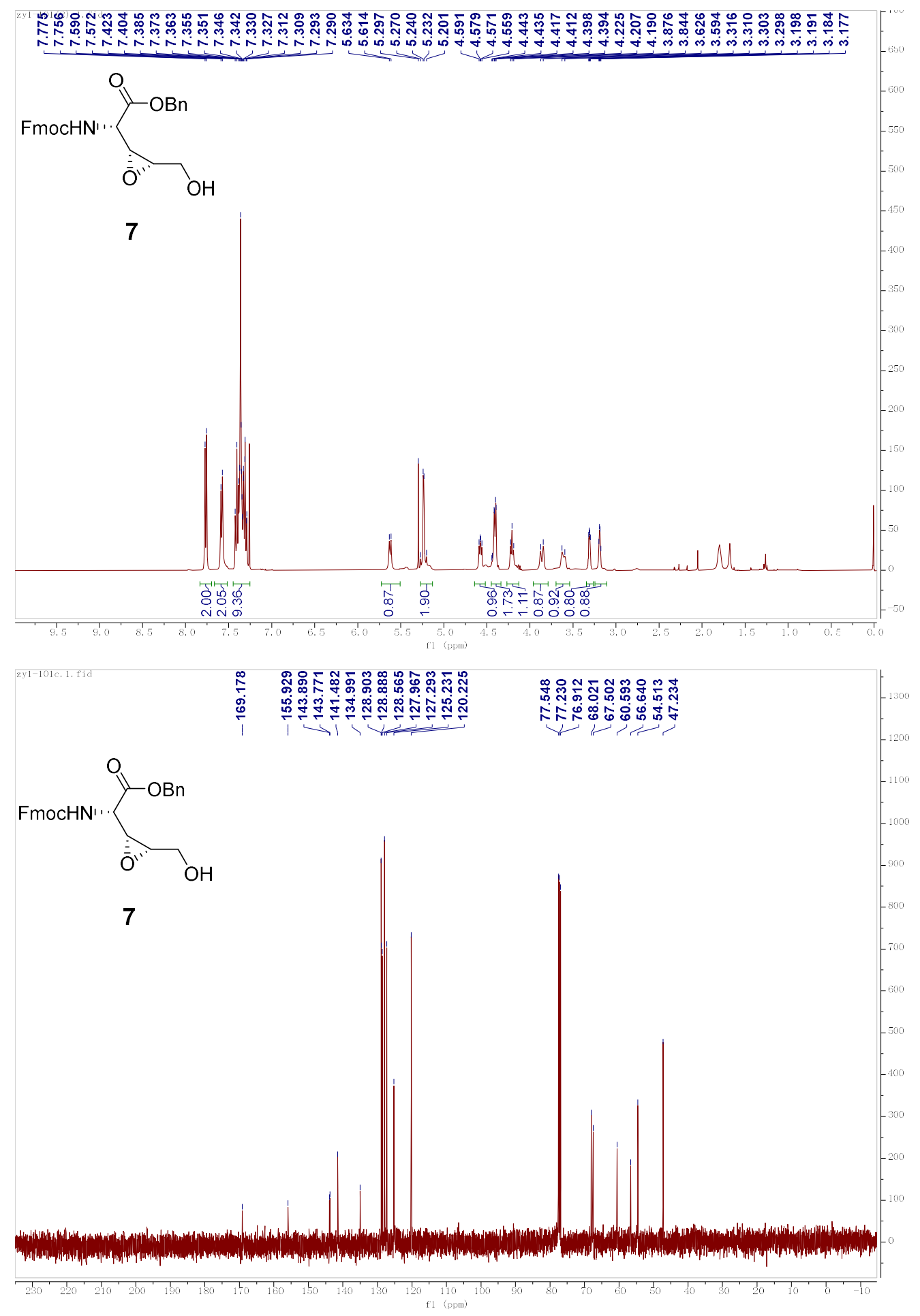
${ }^{1} \mathrm{H}-{ }^{1} \mathrm{H}$ COSY of compound 7

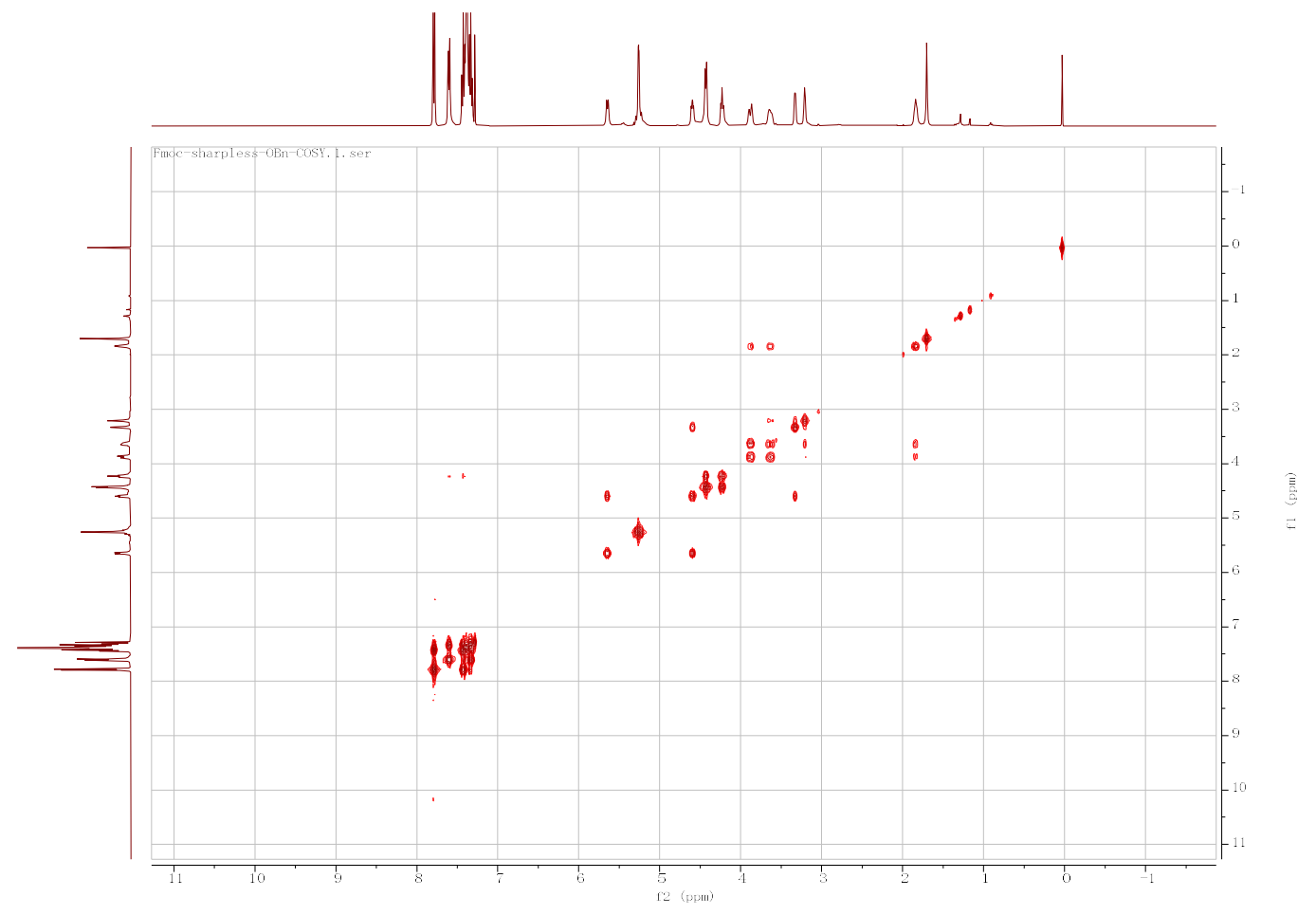



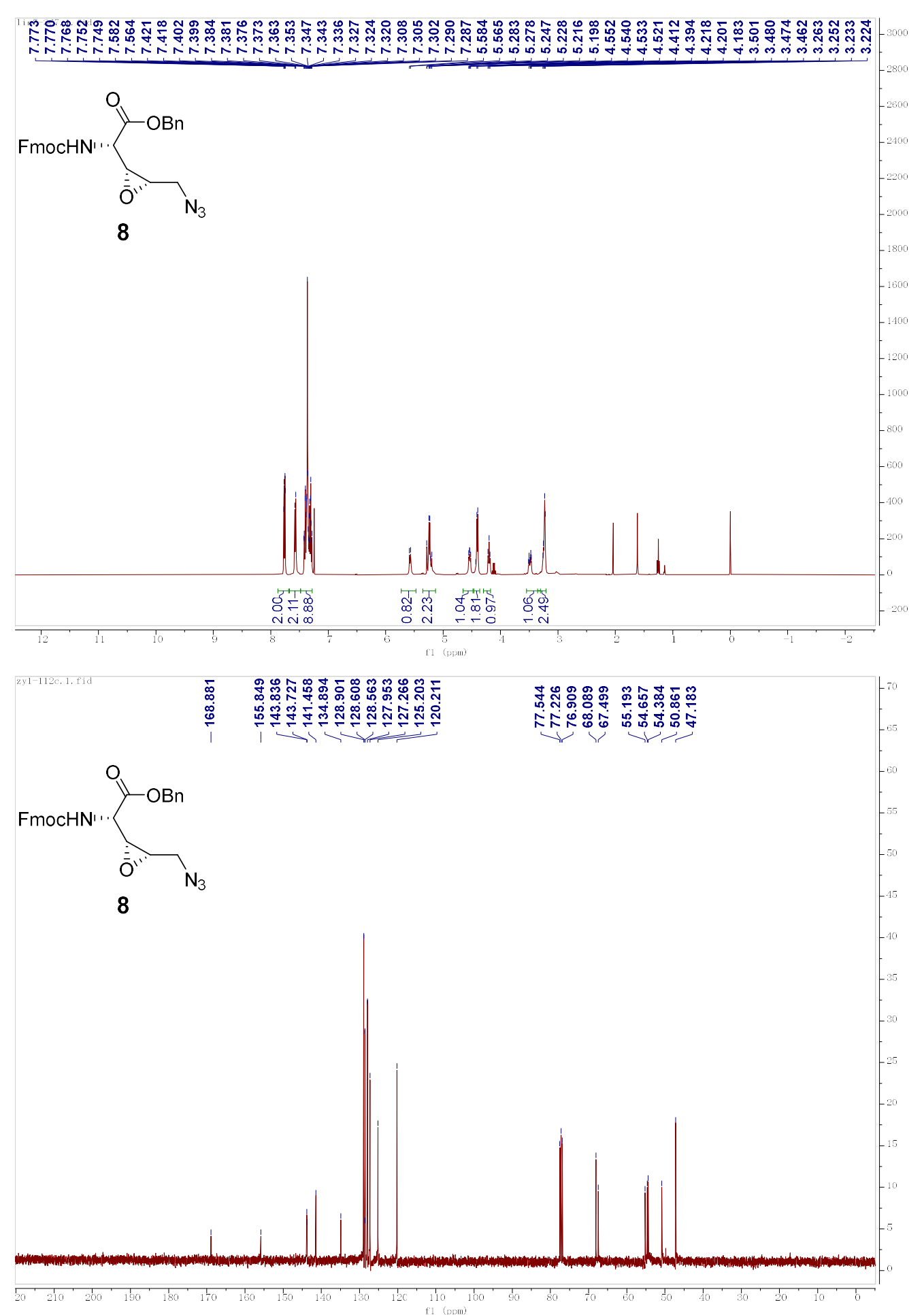

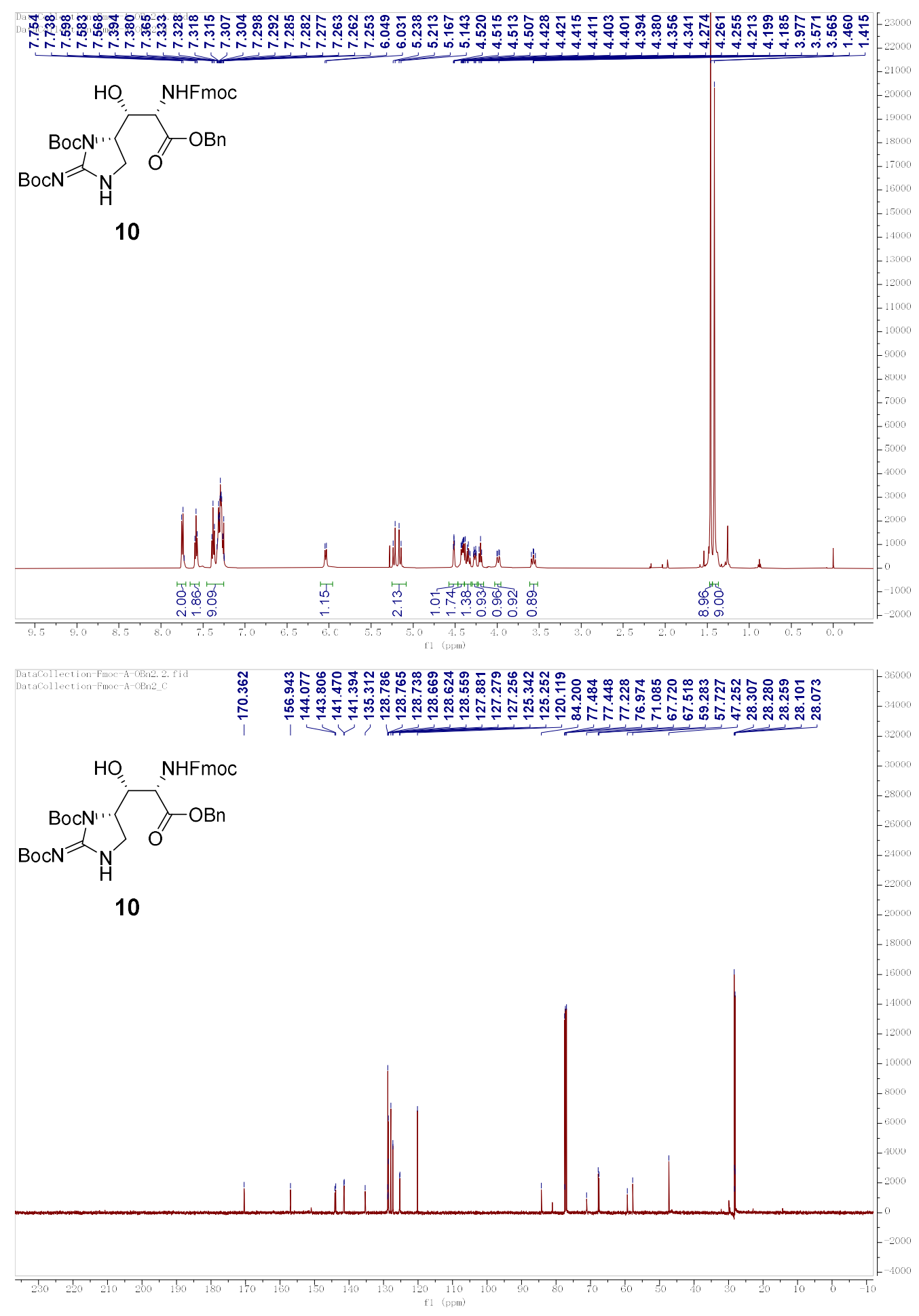


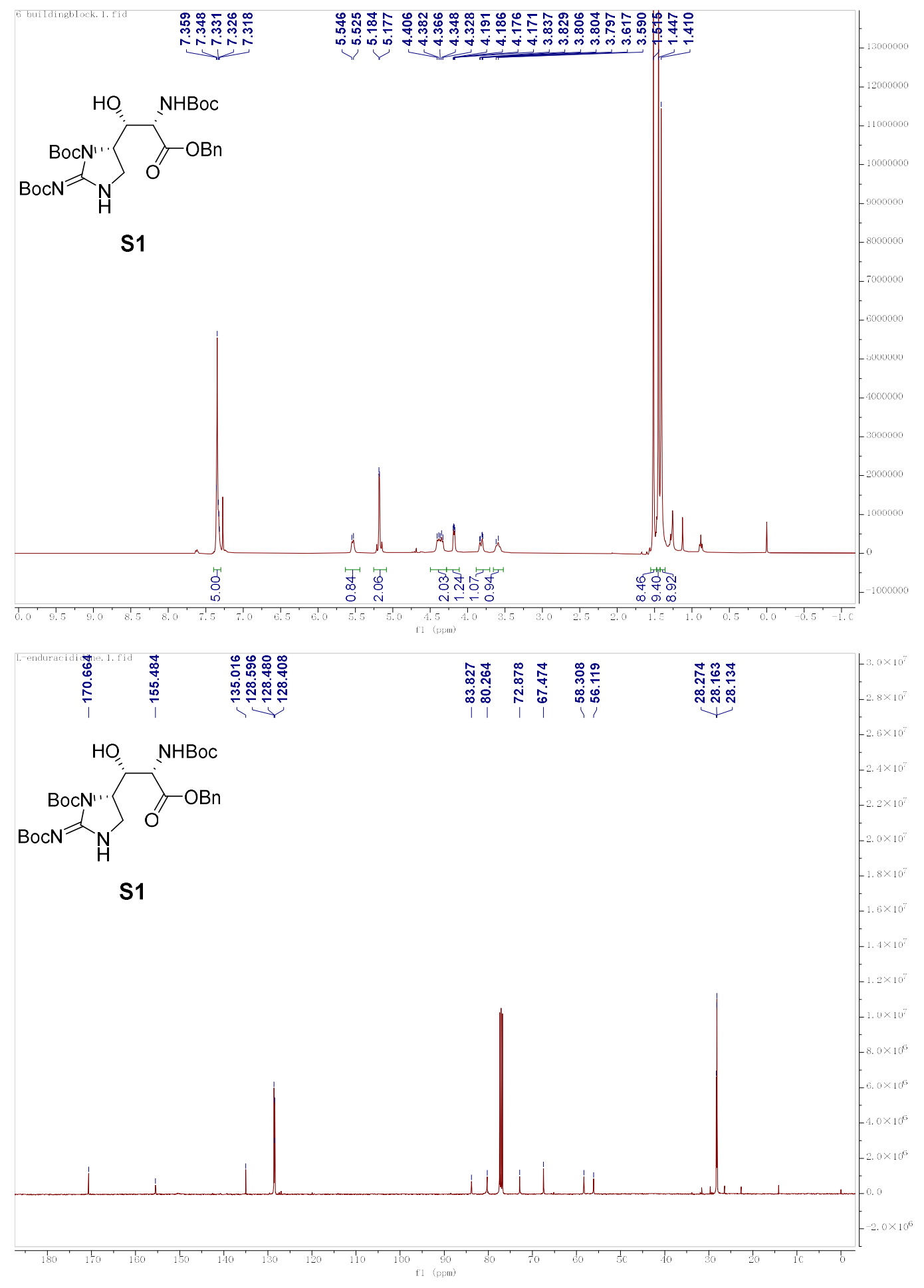


1H-1H COSY of compound S1

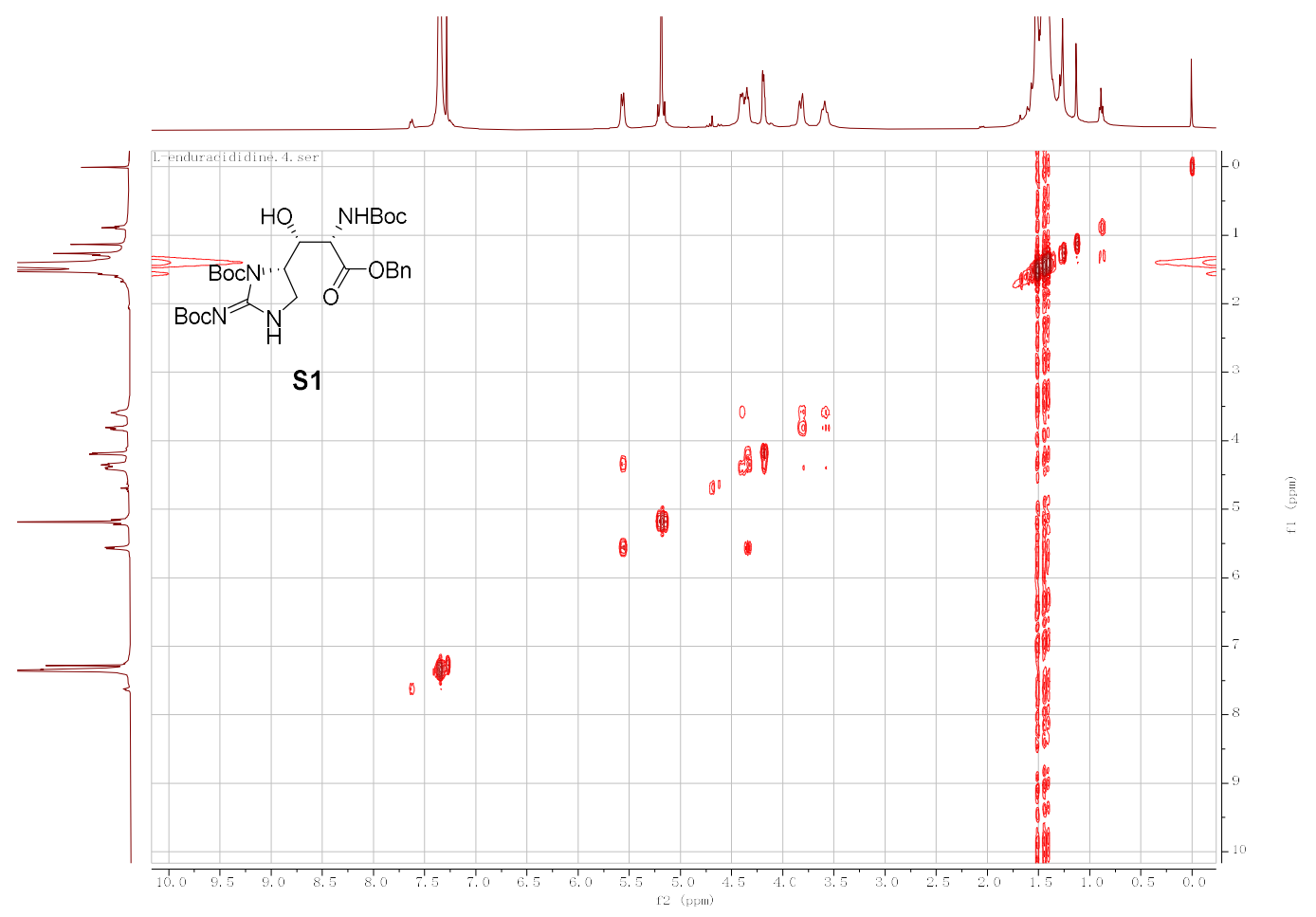




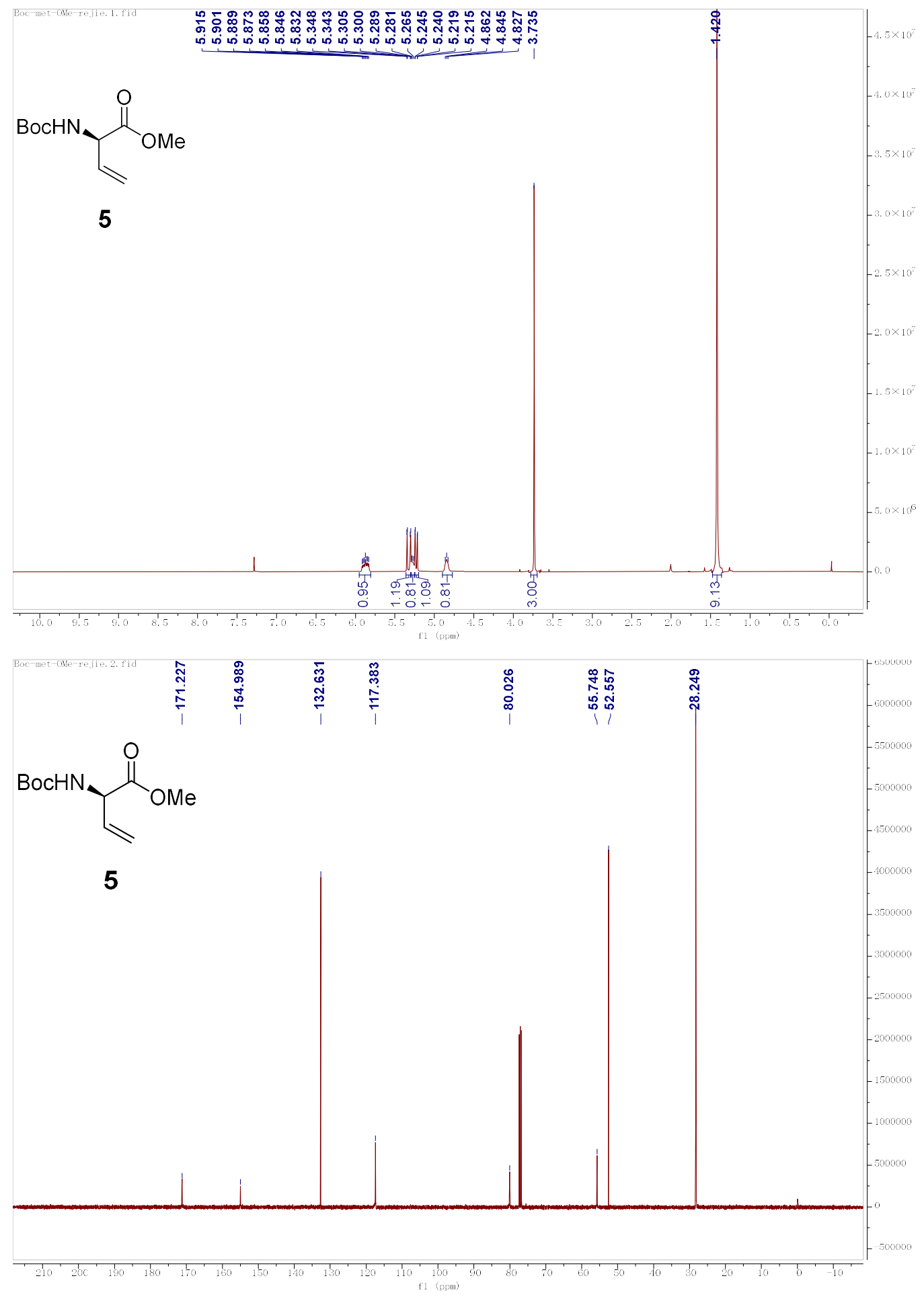



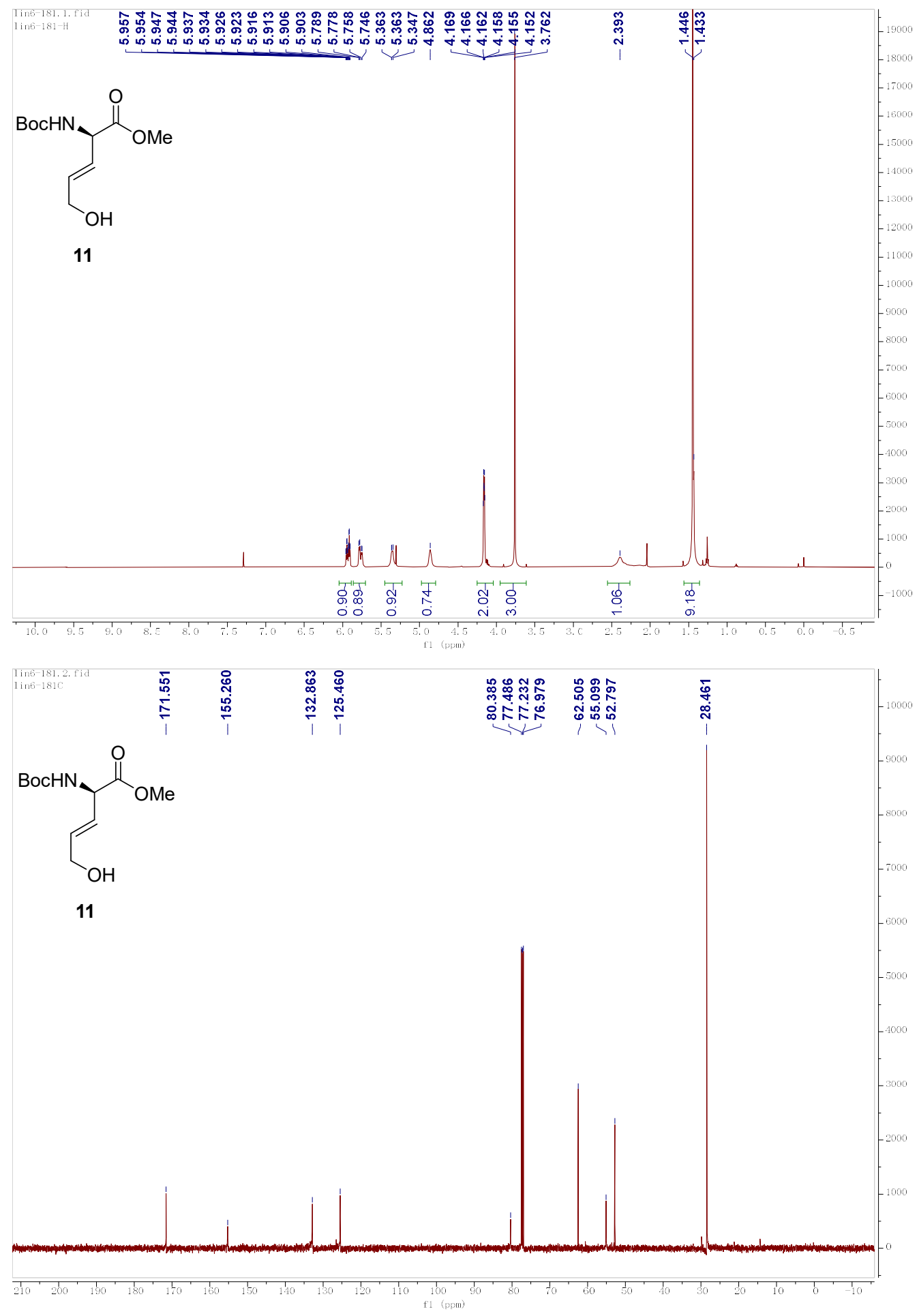

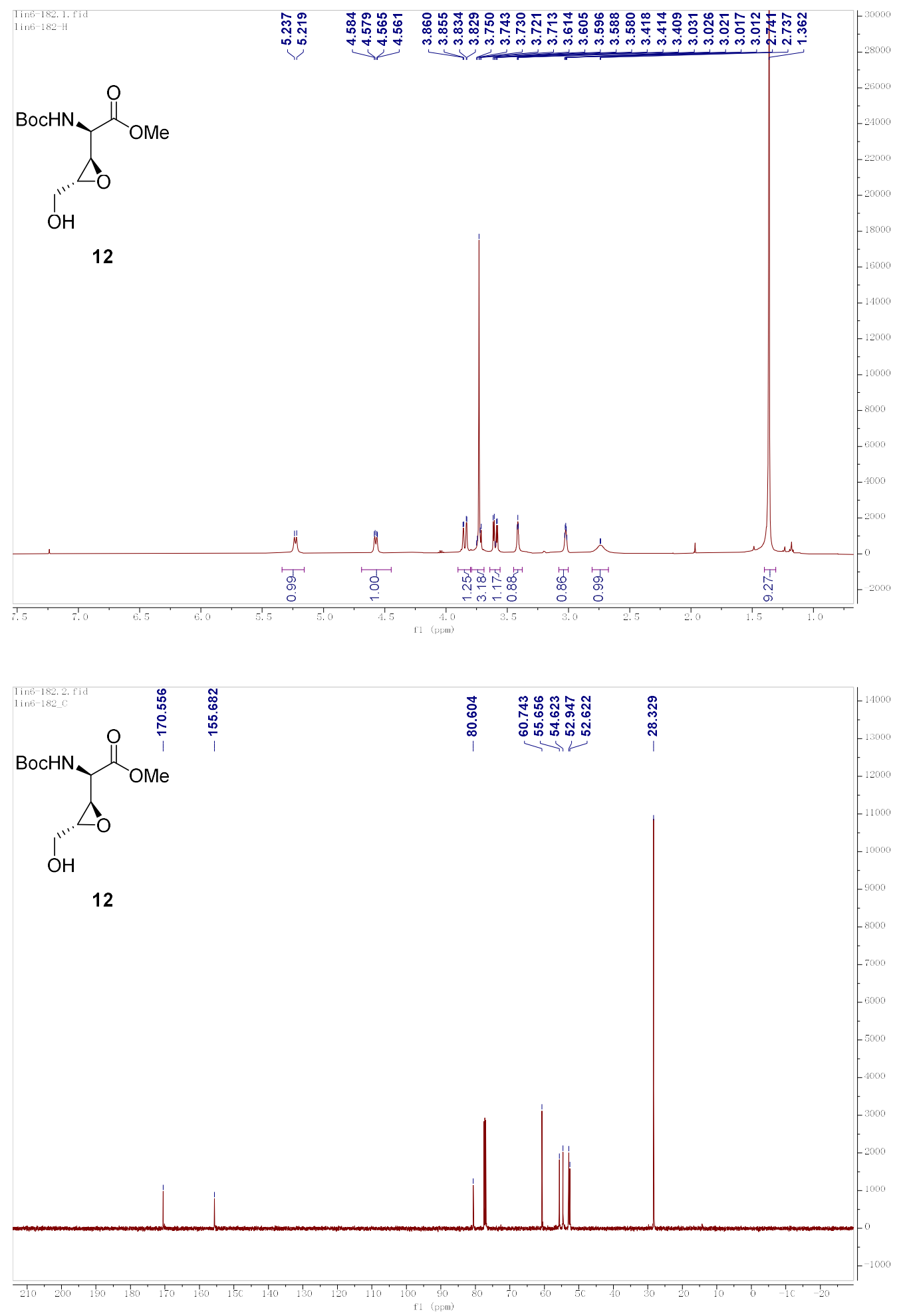


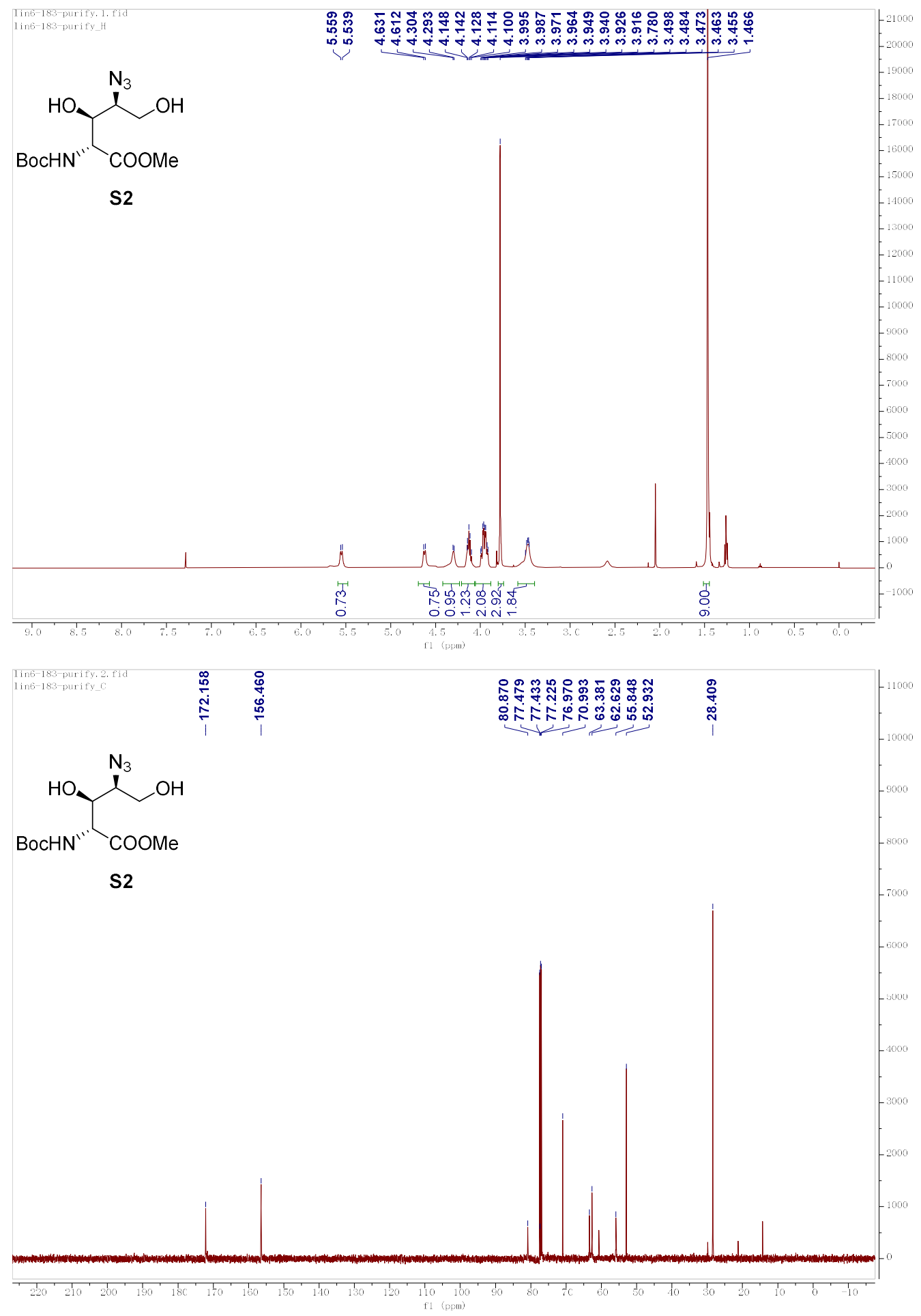



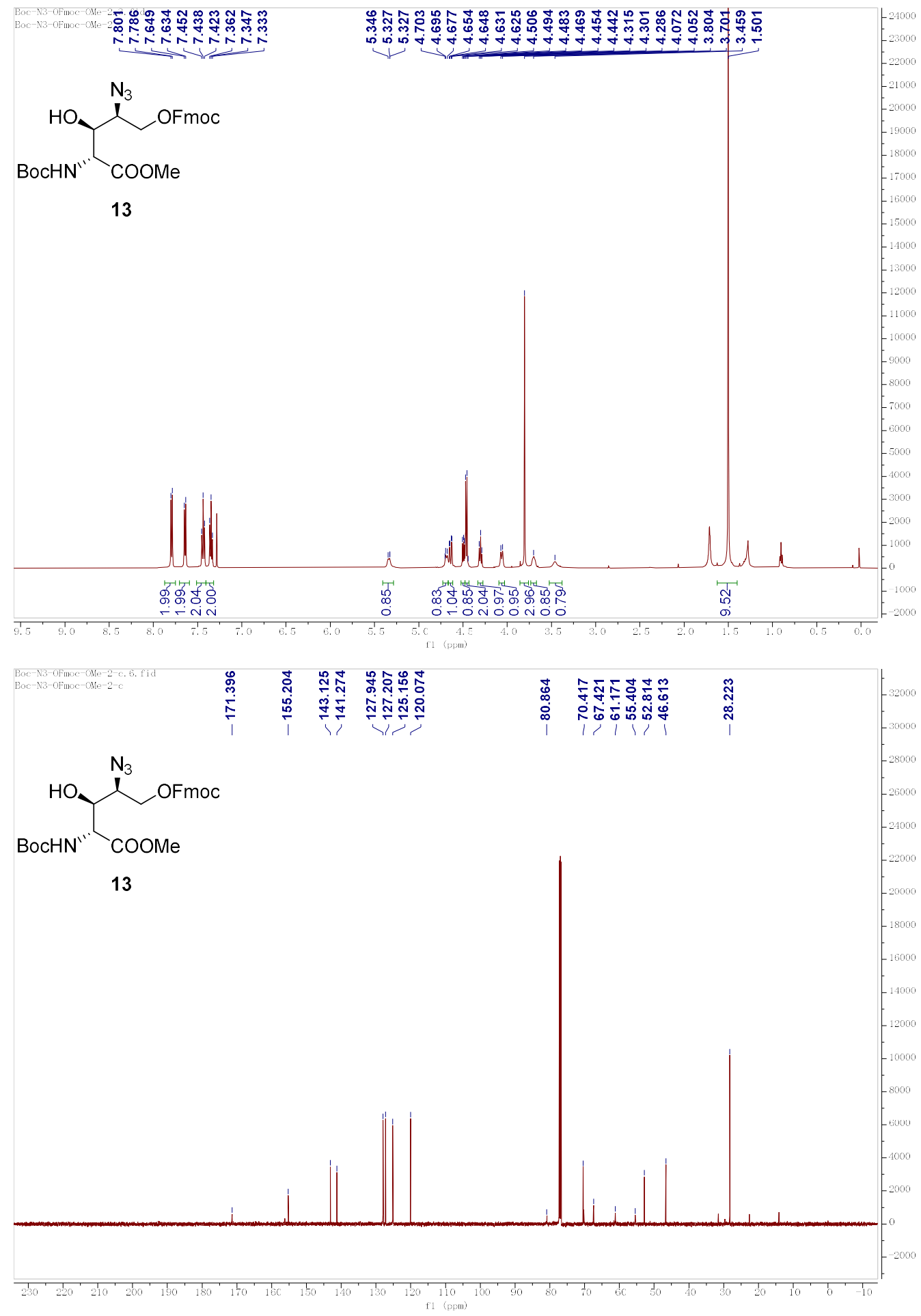

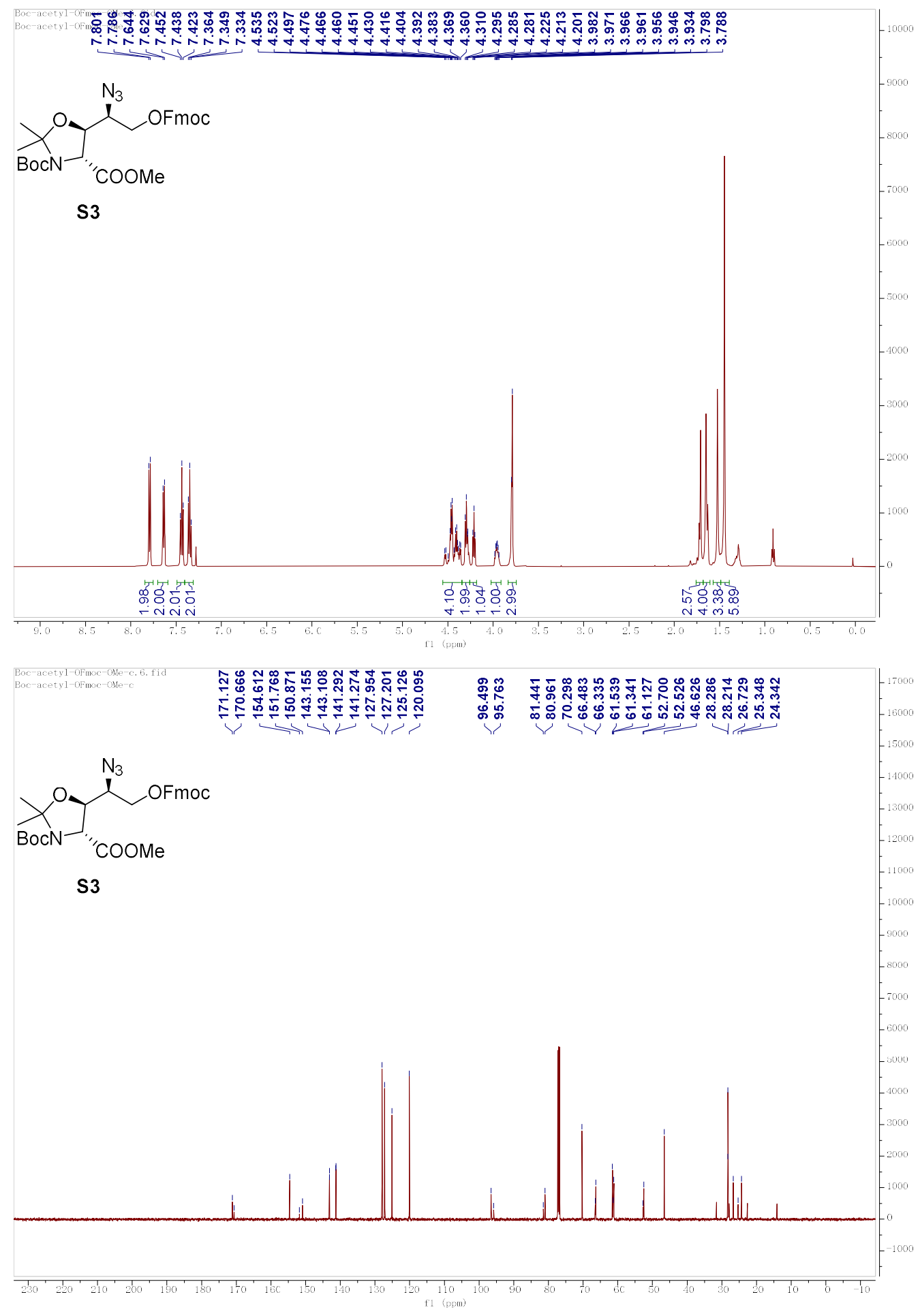

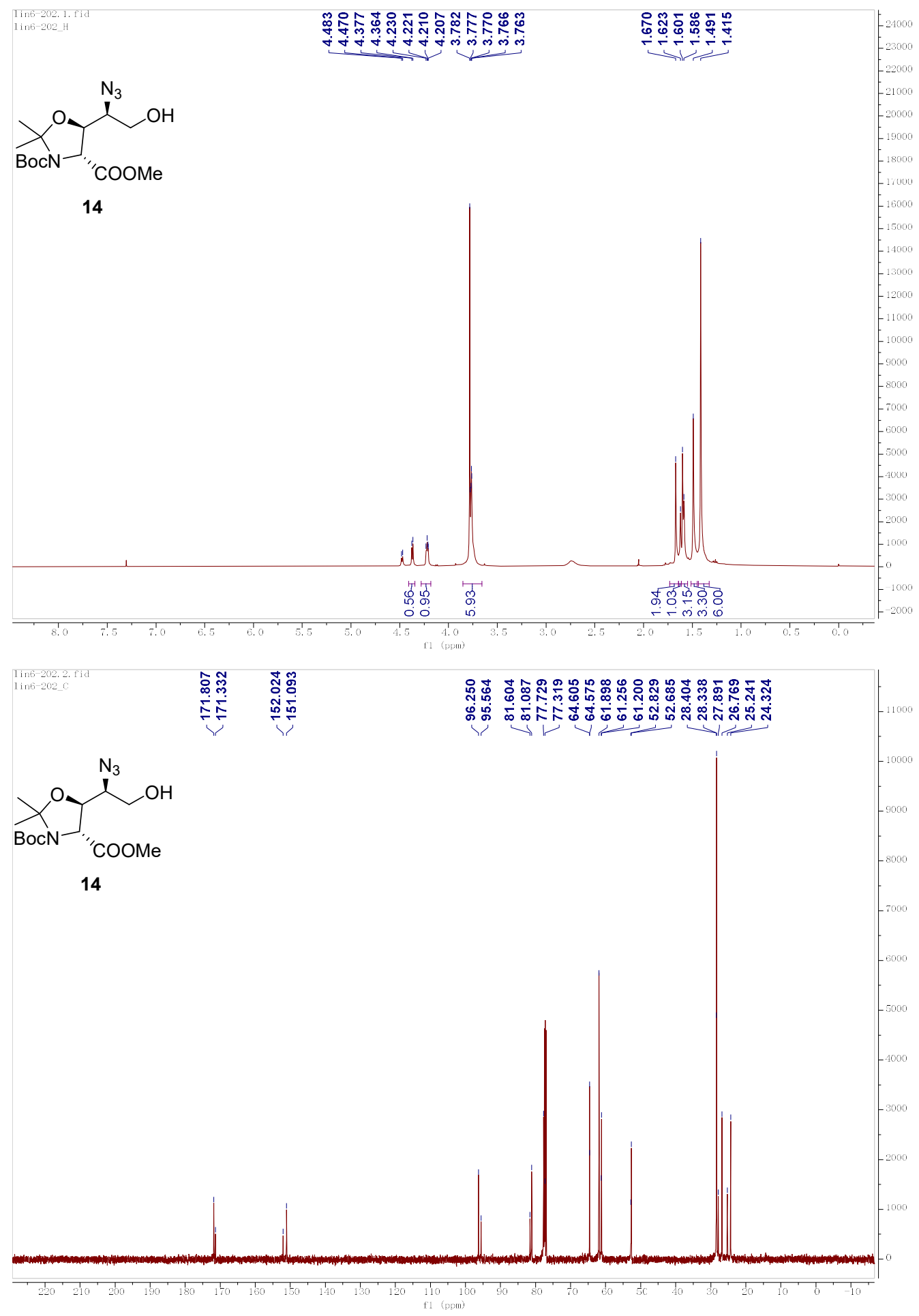

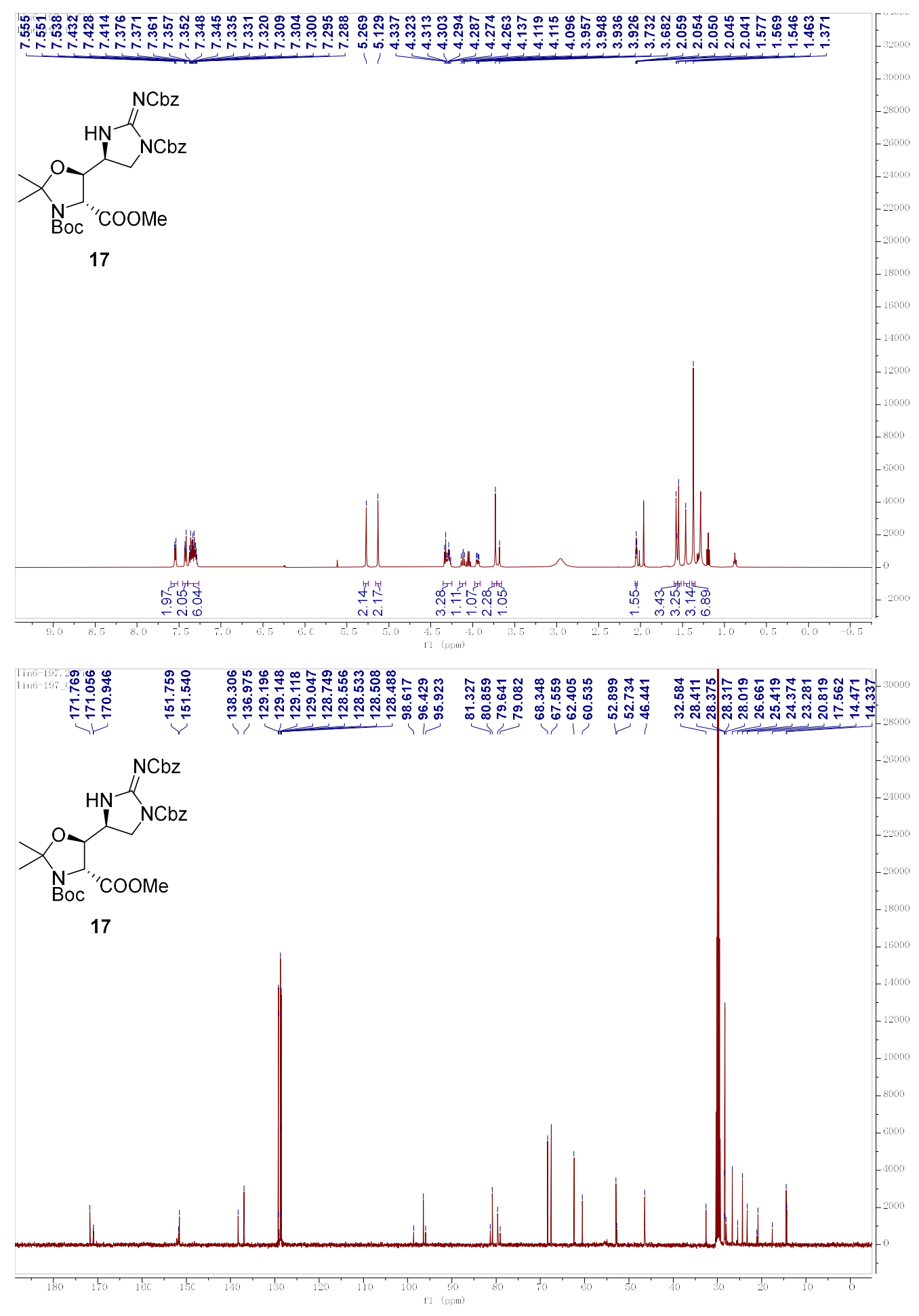

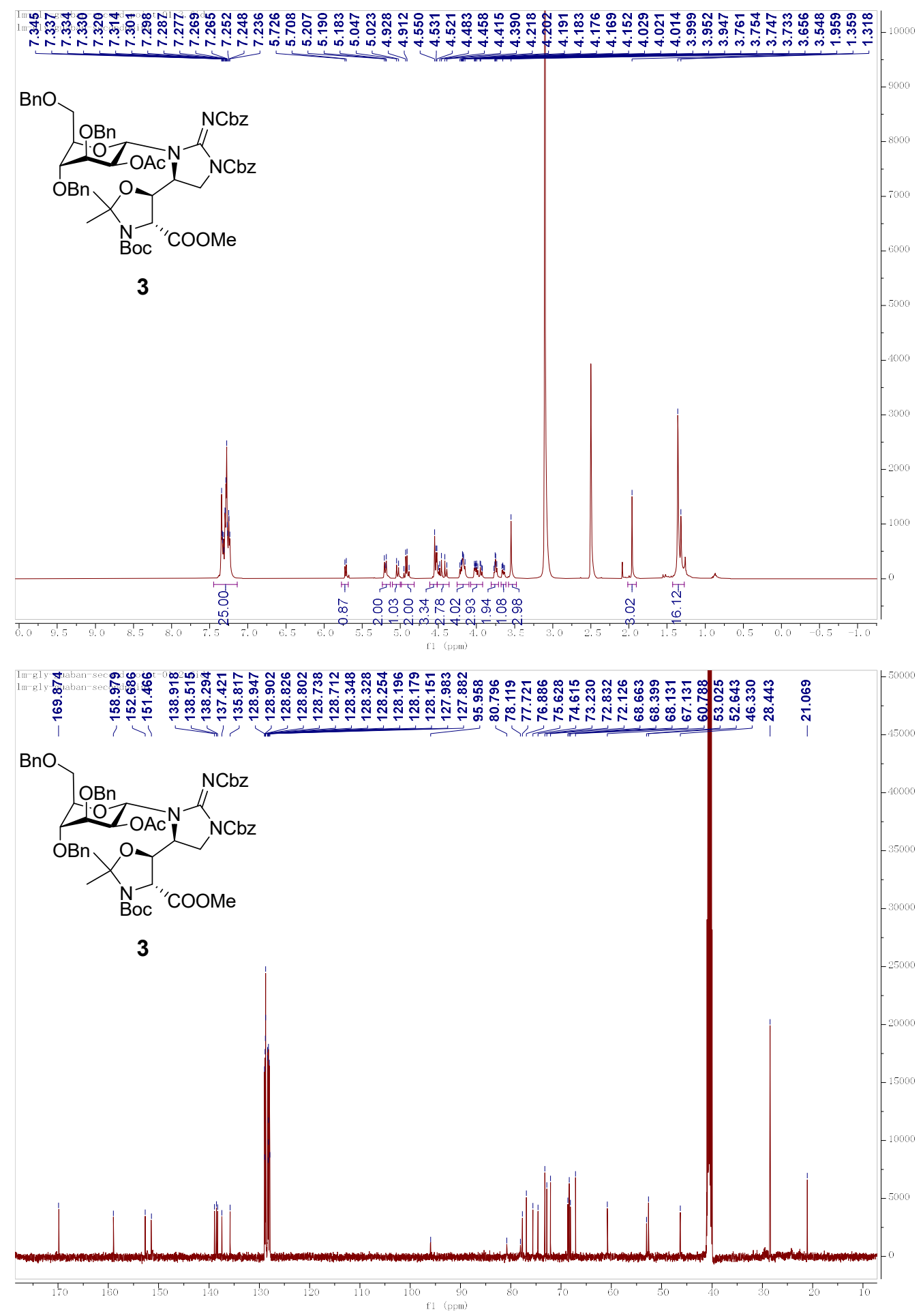


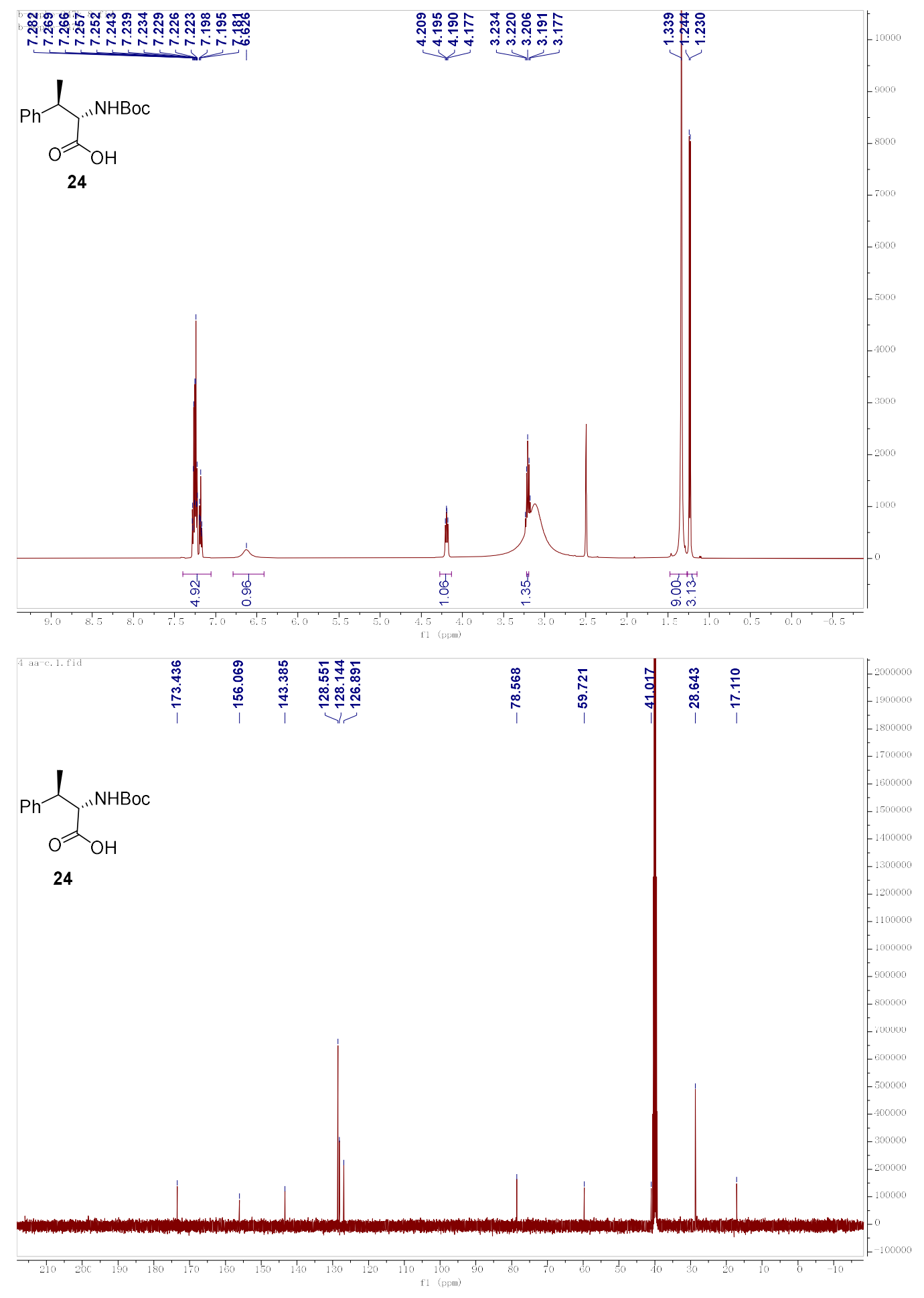



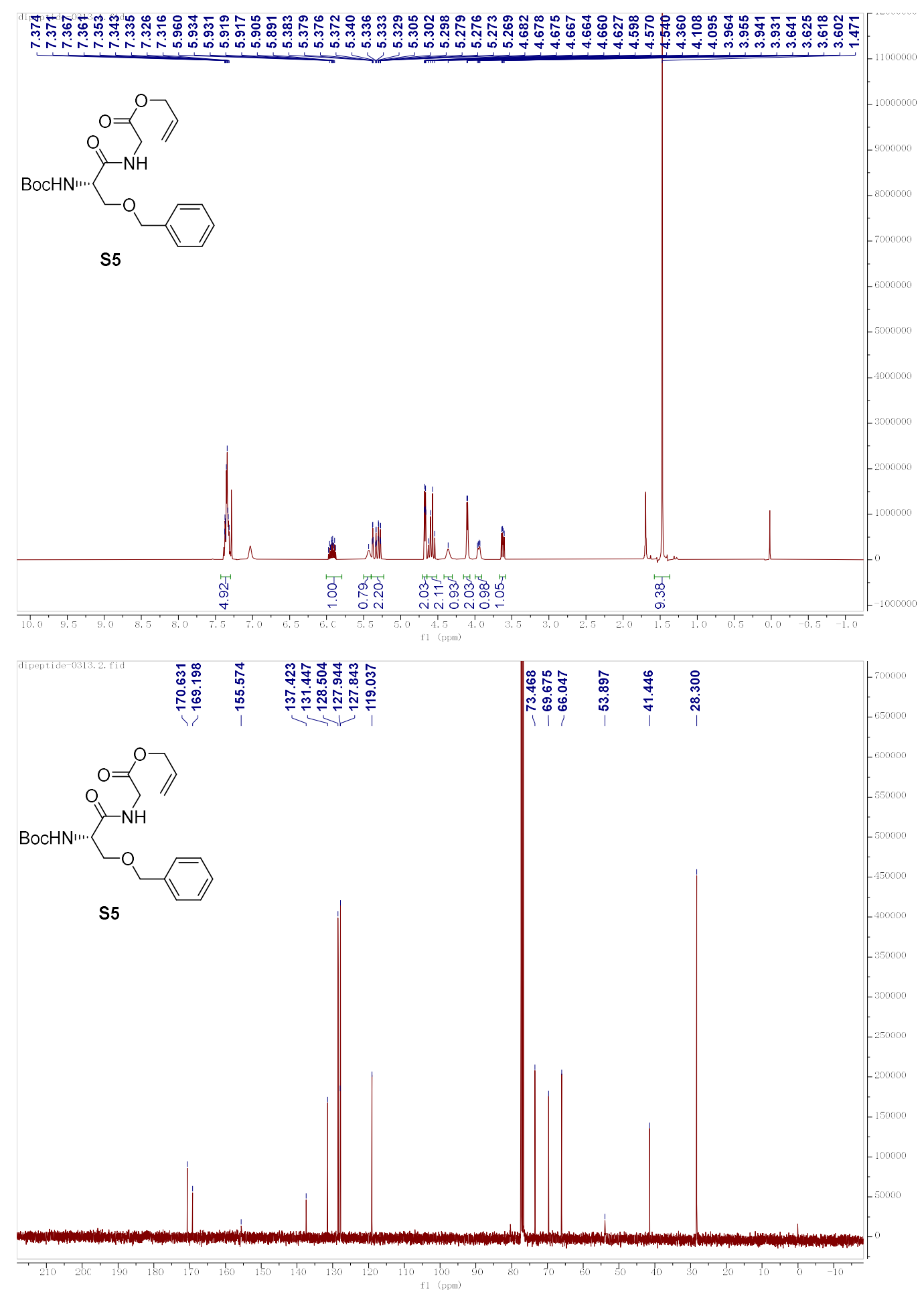

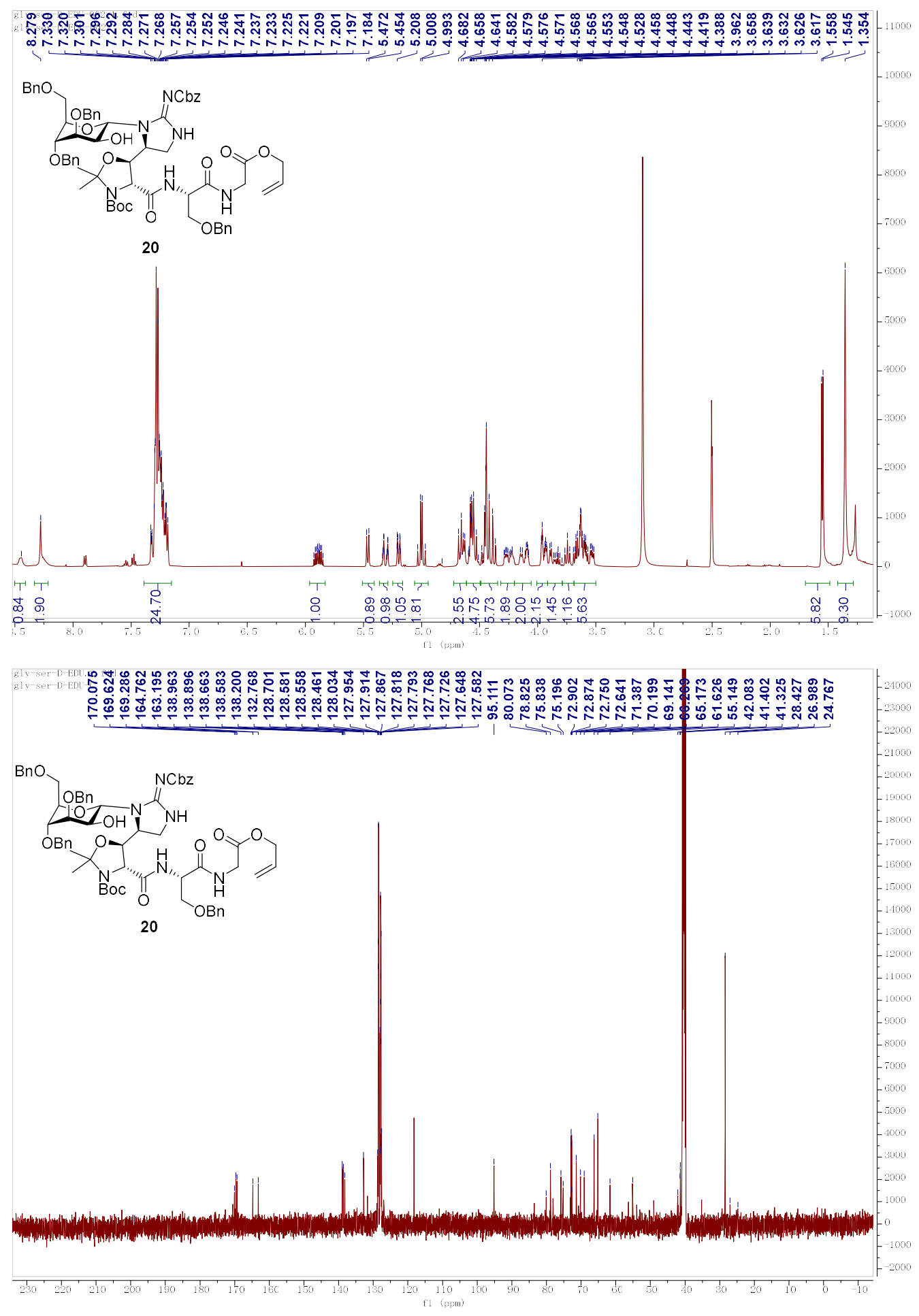

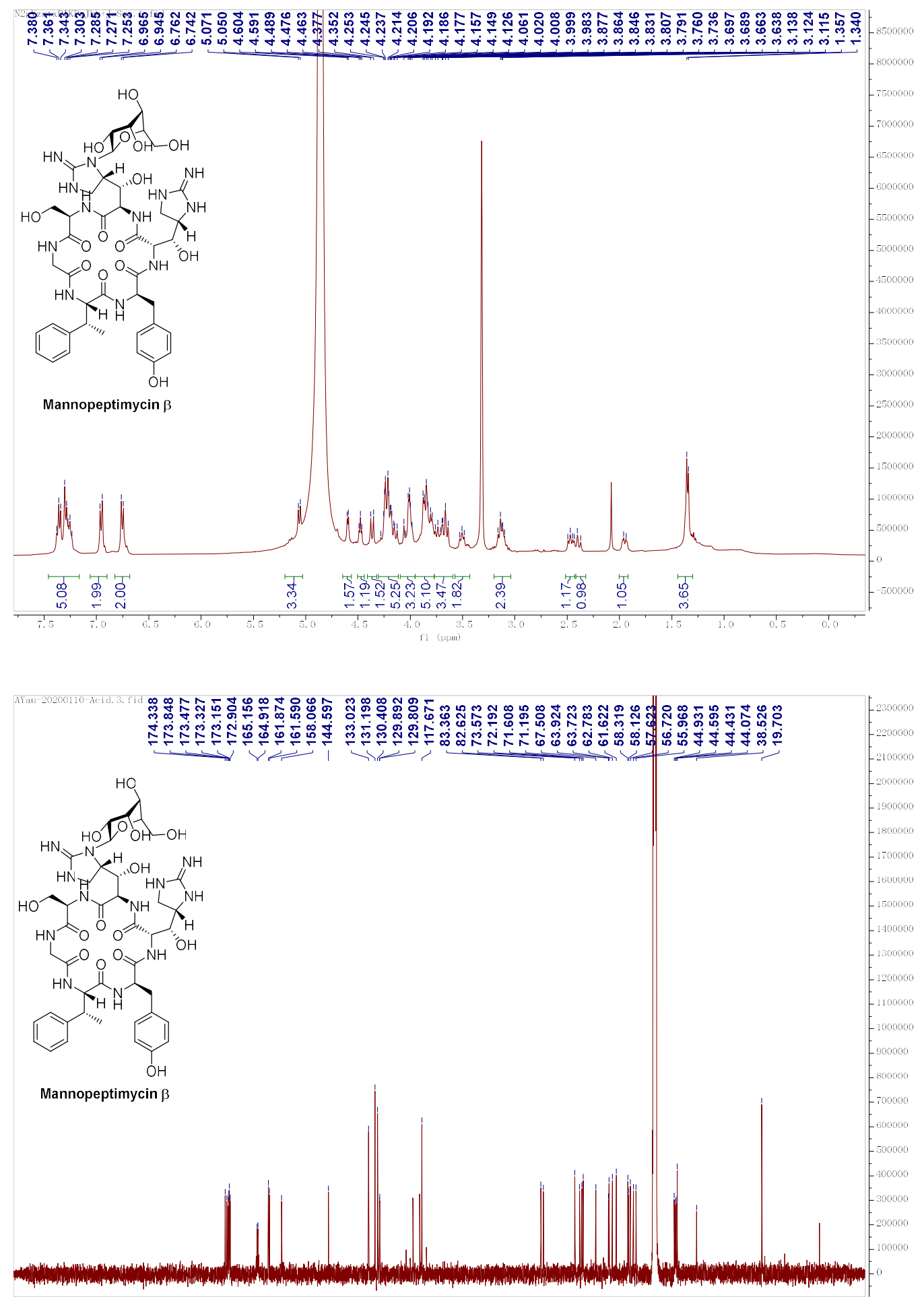
COSY of mannopeptimycin $\beta$

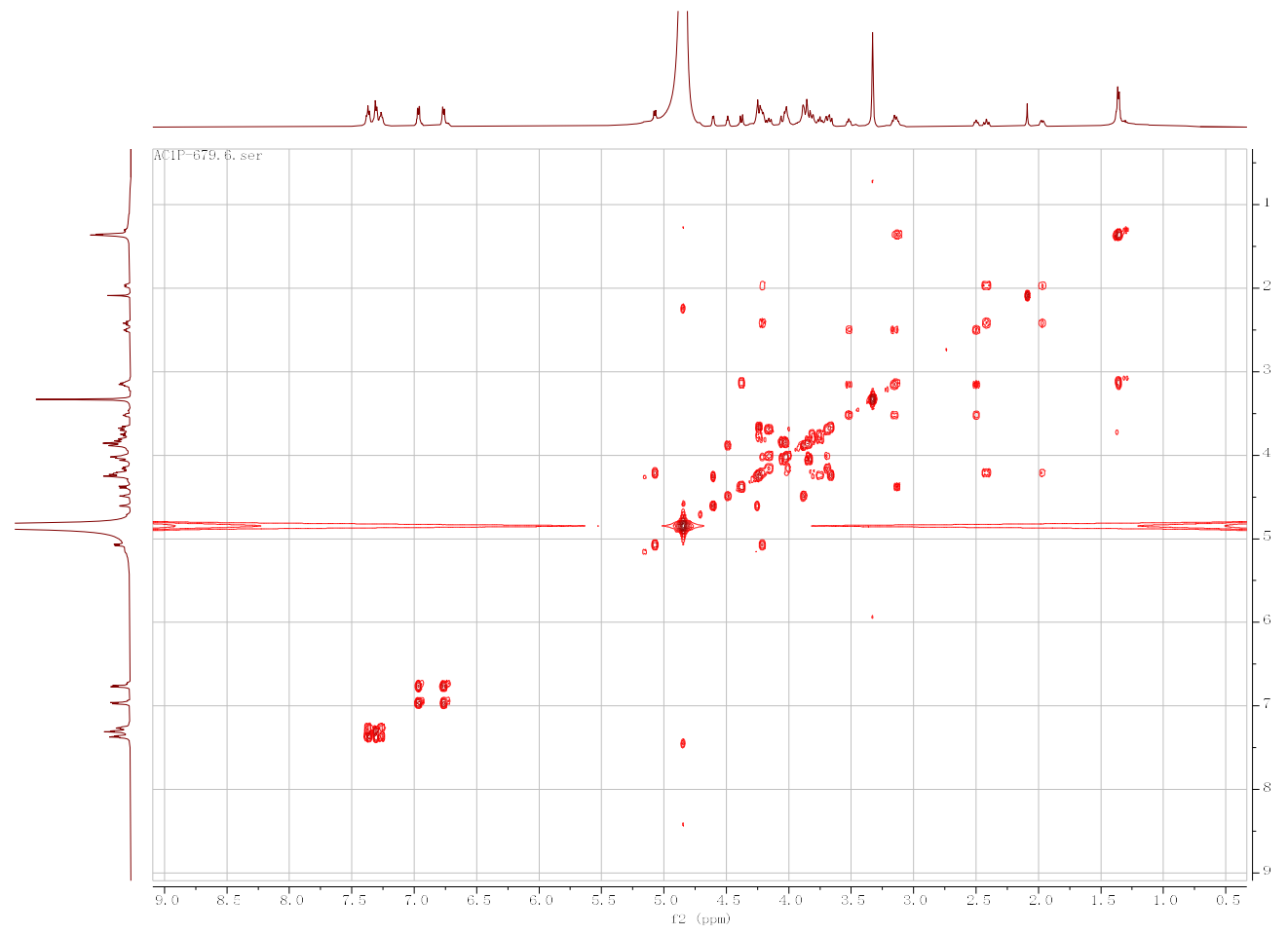

HMBC of mannopeptimycin $\beta$

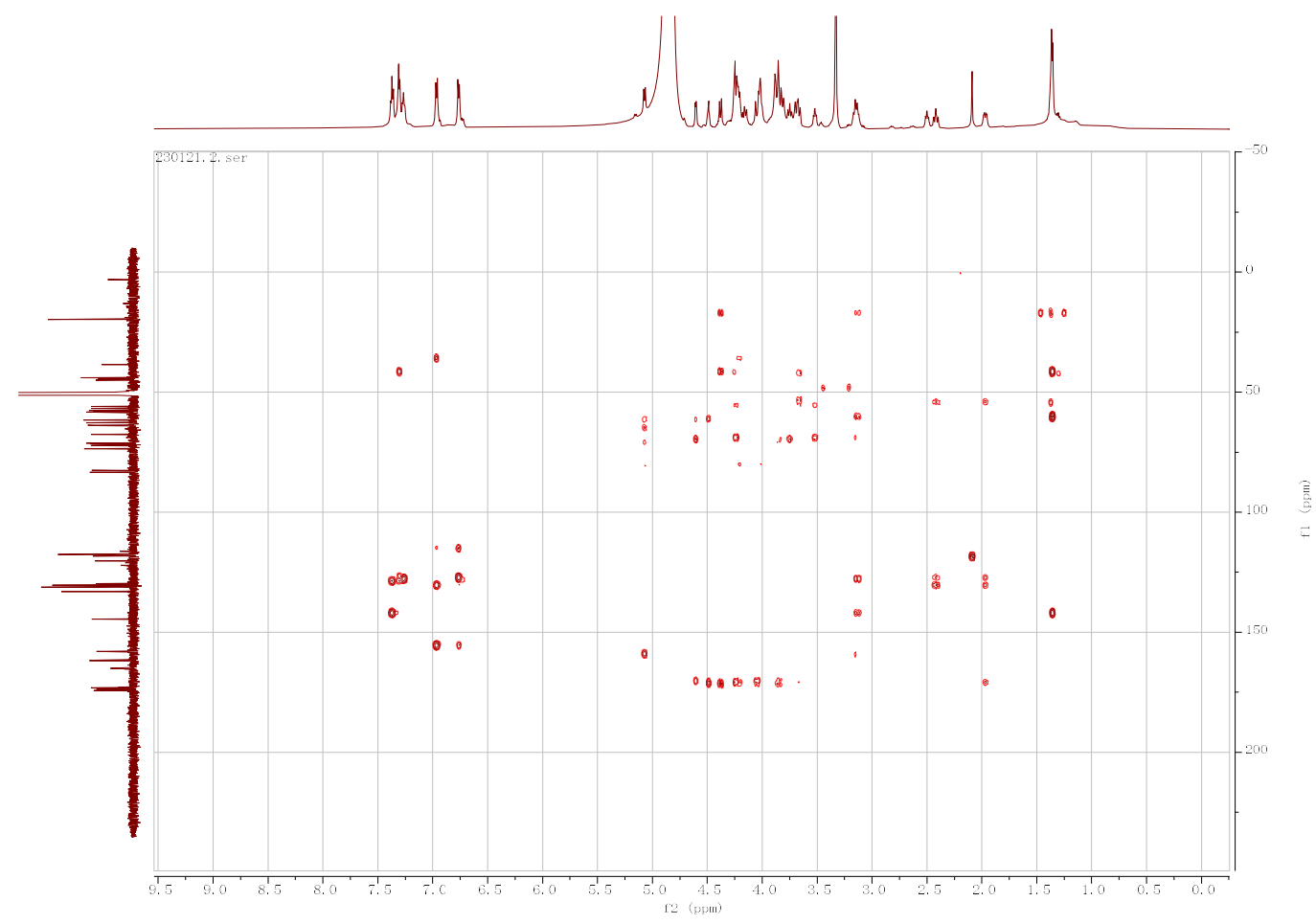


HSQC of mannopeptimycin $\beta$

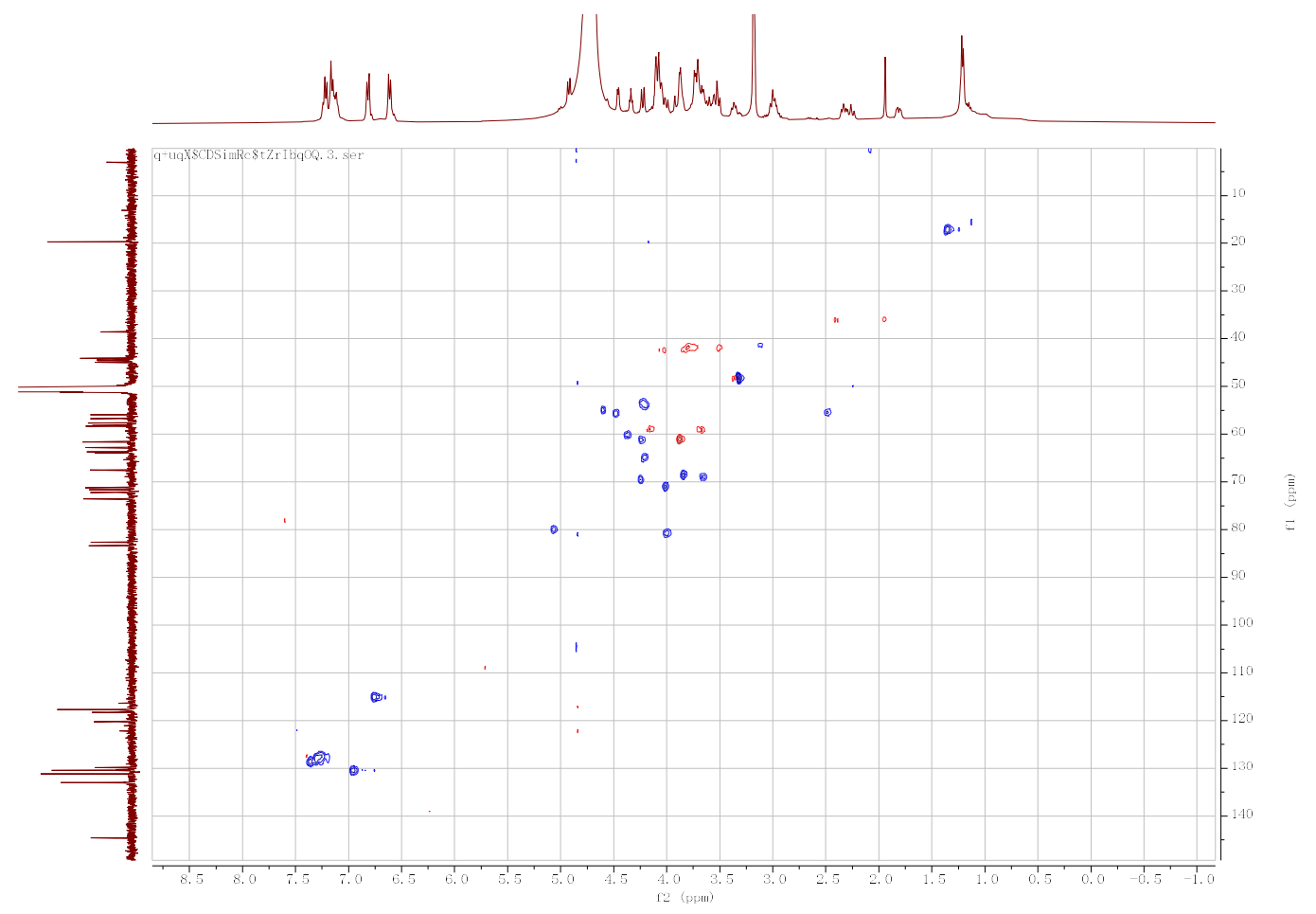




\section{iv. Reference}

[1]. Wang, B.; Liu, Y.; Jiao, R.; Feng, Y.; Li, Q.; Chen, C.; Liu, L.; He, G.; Chen, G.; Total Synthesis of Mannopeptimycins and $\alpha$ and $\beta$. J. Am. Chem. Soc. 2016, 138, 3926-3932.

[2]. Chen, J.; Wang, P.; Zhu, J.; Wan, Q.; Danishefsky, S. J. Application to the Controlled Total Synthesis of Glycopeptides. Tetrahedron. 2010, 66, 2277-2283.

[3]. Wong, C. T. T.; Lam, H. Y.; Song, T.; Chen, G.; Li, X. Synthesis of constrained head-to-tail cyclic tetrapeptides by an imine-induced ring-closing/contraction strategy. Angew. Chem. Int. Ed. 2013, 52, 10212-10215.

[4]. He, H.; Williamson, R.T.; Shen, B.; Graziani, E.I.; Yang, H.Y.; Sakya, S.M.; Petersen, P.J.; Carter, G.T. Novel antibacterial glycopeptides from Streptomyces hygroscopicus, LL-AC98. J. Am. Chem. Soc. 2002, 124, 9729.

[5]. Qiao, Y.; Srisuknimit, V.; Rubino, F.; Schaefer, K.; Ruiz, N.; Walker, S.; Kahne, D. Lipid II overproduction allows direct assay of transpeptidase inhibition by $\beta$-lactams. Nat Chem Biol. 2017, 13, 793-798.

[6]. Ling, L. L.; Schneider, T.; Peoples, A. J.; Spoering, A. L.; Engels, I.; Conlon, B. P.; Mueller, A.; Schaberle, T. F.; Hughes, D. E.; Epstein, S.; Jones, M.; Lazarides, L.; Steadman, V. A.; Cohen, D. R.; Felix, C. R.; Fetterman, K. A.; Millett, W. P.; Nitti, A. G.; Zullo, A. M.; Chen, C.; Lewis, K. A new antibiotic kills pathogens without detectable resistance. Nature, 2015, 517, 455-459.

[7]. Jin, K.; Po, K. H. L.; Kong, W. Y.; Lo, C. H.; Lo, C. W.; Lam, H. Y.; Sirinimal, A.; Reuven, J. A.; Chen, S.; Li. X. Synthesis and antibacterial studies of teixobactin analogues with nonisostere substitution of enduracididine. Bioorg. Med. Chem. 2018, 26, 1062-1068. 